\title{
Reading Rape in Livy's History of Rome, Shakespeare's The Rape of Lucrece, and J.M. Coetzee's In the Heart of the Country
}

\author{
By
}

Erin Scudder

A Thesis

Submitted to the Victoria University of Wellington in Fulfilment of the Requirements for the Degree of

Master of Arts

in English Literature

School of English, Film, Theatre \& Media Studies

Victoria University of Wellington

2010 
For Emma. 


\section{CONTENTS}

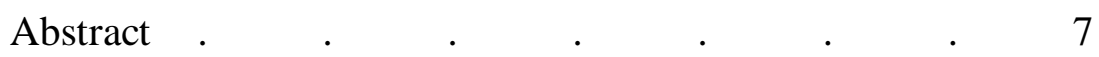

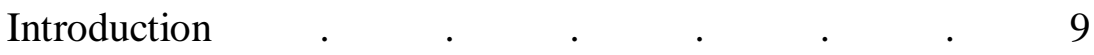

PART ONE: Lucretia and The Sabine Women

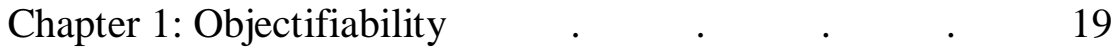

Chapter 2: Ownership $\quad$. $\quad$. $\quad$. $\quad 39$

Chapter 3: Violence $\quad$. $\quad$. $\quad$. $\quad$. 49

PART TWO: Magda

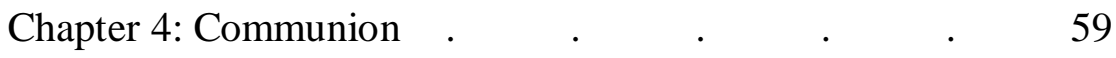

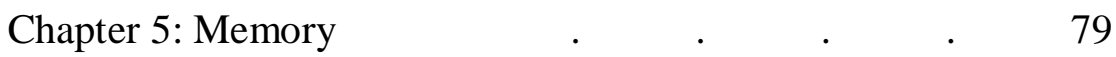

Chapter 6: The Abuse of Pleasure $\quad$. $\quad$. $\quad$. 95

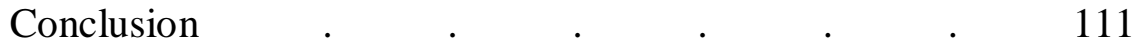

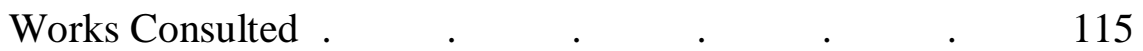




\begin{abstract}
Mieke Bal argues that rape "takes place inside. In this sense, rape is by definition imagined; it can exist only as experience and as memory, as image translated into signs, never adequately 'objectifiable' "(100). In this thesis, by critically examining some ways in which rape has been made to seem objectifiable in literature, I argue that rape cannot simply be 'seen' from a "point-of-viewless" (Rooney 89) perspective. My argument supports Catharine A. MacKinnon's call for a rethinking of rape-related "legal process as one involving a choice between incommensurate meanings rather than one of uncovering a (temporarily hidden) fact, the Truth" (Rooney 90). I argue that, in Livy's History of Rome and Shakespeare's The Rape of Lucrece, rape is portrayed as an objectifiably visible spectacle; the rape victim's description of rape functions in a capacity analogous to testimony, supporting "rape law's assumption that a single, objective state of affairs existed" (MacKinnon 654); and the rape victim's post-rape, self-inflicted violence functions as a form of self-punishment which references historically specific correlations between female unchastity and socio-political calamity. In contrast, I argue that, in J.M. Coetzee's novel In the Heart of the Country, the narration discourages readers from accepting the objectifiability of the rape which it relates; the narrator's "meditations" (Gallagher 82) deviate from the conventions of testimony, expressing instead the "incommensurate meanings" (Rooney 90) that rape holds for the victim herself; and the descriptions of violence, abuse, and victim response present the chance for readers to interpret the aftermath of rape in a manner other than that which "conveys the idea that the victim is responsible for her own destruction" (Bal 100).
\end{abstract}




\section{INTRODUCTION}

Of a critical collection of essays entitled Rape in Antiquity, reviewer James Davidson noted that

There is much work to be done on the cultural construction of volition, violation, permission, and personhood as well as on the basic terminology of rape and its epistemology before the next collection. (534)

What kind of work is Davidson suggesting be done in relation to the "cultural construction," "terminology," and "epistemology" of which he writes next? I think there is an important distinction to be made between, for example, an endeavour to define "a basic terminology of rape" and an investigation into the reasons why "a basic terminology of rape" has been so difficult to establish.

In this study I am expressly concerned with 'doing the work' of the latter project, and my investigation will be specifically concerned with the difficulties of defining and describing rape in literature (fictional and historiographical). I am interested in exploring the possibility that the "cultural construction of volition, violation, permission and personhood" - precisely because changeable - complicates the possibility of formulating a "basic terminology of rape" (534) that one might use, for example, to analyse rape narratives across the ages.

After reading J.M. Coetzee's In the Heart of the Country I set out to research earlier rape narratives from Greek and Roman antiquity. My objective in doing so was to ground my reading of Coetzee's novel as a rape narrative in the context of a broader consideration of rape narratives and their conventions. Ultimately, I decided to focus upon a selection of rape narratives sourced from ancient Rome, ${ }^{1}$ and more specifically to two of those included in

\footnotetext{
${ }^{1}$ Occasionally I also make brief reference to some narratives sourced from Greek antiquity (when, for example, facets of Greek narratives echo or form an interesting counterpoint to the conventions I am discussing). For
} 
Livy's History of Rome: the rape of Lucretia and the rape of the Sabine women. The story of the rape of Lucretia has been particularly popular in literary and literary critical history, and I am also concerned herein with the analysis of a subsequent, Renaissance era version of the story, Shakepeare's poem The Rape of Lucrece. ${ }^{2}$

In part one I will begin by analysing some of the understandings of rape played out in these earlier narratives. This analysis will form a comparative basis for much of the discussion of Coetzee's novel In the Heart of the Country, which I analyse in part two. My purpose in this comparative exercise is related, in manifold ways, to the question "why has "a basic terminology of rape and its epistemology" (Davidson 534) been so difficult to establish?'

Firstly, reading Livy and Shakespeare's narratives for the plot of rape - to determine, that is, what kind of crime rape is understood to be within those diegeses, and how, therefore, it is responded to by the characters involved - illustrates for a contemporary reader that rape has not always been written as the same sort of crime. The project of defining a "terminology of rape" is complicated, then, by the fact that the term 'rape' itself has meant different things in different narratives.

Secondly - insomuch as it comprises a cursory survey of selected rape narratives this comparative exercise serves to illustrate that epistemological difficulty (difficulty, that is, in knowing what is happening, or how to represent it) is something that recurs thematically within the diegeses of these narratives. Lucy Valerie Graham surmises that "In canonical literary narratives of the West, rape is often depicted as 'unspeakable', as severed from articulation," and argues that references to older stories in contemporary rape narratives highlight "Western artistic traditions in which rape has had a fraught relationship with articulation or representation" ("Reading" 439). Sabine Sielke has also argued that "theorists of narrative and visual poetics acknowledge that rape in many ways resists representation" (4). The recurrence of 'representational difficulty' as a thematic component of rape narratives suggests that something about rape (whatever kind of crime it is understood to be) recurringly defies portrayal and the sort of itemisation of its components that could facilitate the formulation of a "basic terminology" with which to describe it.

example, I mention the rape of Philomela on page 20 of this thesis, and briefly discuss the Callisto and Medusa narratives on pages $48-9$.

2 Throughout this thesis, my use of 'Lucretia' or 'Lucrece' will usually depend upon whether I'm referring to Livy's or Shakespeare's narrative. However, occasionally I make reference to the ways in which the 'Lucretia story' has been realised by different literary and/or visual artists over the centuries. In these cases, for the sake of simplicity, I will use Livy's spelling. 
Thirdly, my work in part one will give an idea of rape's history in some Western literature as an allegorical vehicle for political unrest. Patricia Klindienst Joplin, for example, refers to the Lucretia story as that which is "commemorated by tradition as the event that precipitated the overthrow of hated monarchy and the founding of the Republic about 510 B.C," and the Verginia story as that which marks "the establishment of the Twelve Tables of Roman Law and the overthrow of the corrupt Decemvirs in 450 B.C." ("Ritual" 52). Diane Wolfthal cites an illustrative verse that accompanied a pictorial rendition of the rape of the Sabines in the 1758-50 edition of Cesare Ripa's Iconologia:

'The rape of the Sabines eliminated unhappy wars;

the barbaric theft brought about happy results' [...].

'The Sabines' rape, one must concede,

With the Romans peace did breed.' (28)

The political dimensions of these narratives are of interest - for the sake of comparison - to my study of Coetzee's contemporary rape narratives, which also situate rape at the intersection of political and personal significance. Again, this poses problems for the formulation of a "basic terminology of rape" (Davidson 534): it gives us cause to ask whether the words used to describe rape are sometimes deployed to stand for something other than rape itself.

In chapter one, I discuss the ways in which certain narratives and works of art including Livy's The History of Rome and Shakespeare's The Rape of Lucrece - define rape, noting that these definitions have been unstable and varied. I argue that Livy's and Shakespeare's narratives portray rape as objectifiable, an approach which is at odds with Mieke Bal's assertion that rape is "physically, as well as psychologically, inner" and therefore "can exist only as experience and as memory, as image translated into signs, never adequately 'objectifiable'" (100).

In chapter two, I discuss the different ways in which, in Livy's and Shakespeare's narratives, rape's criminality is determined. I relate aspects of these narratives to historically specific, socio-cultural contexts wherein rape was considered criminal when it was understood - by those with authority - as an offense against chastity. I describe how, within these diegeses, the criminality of rape is gauged on the basis of how much harm it causes to particular men, and how the prerogatives associated with suffering and the enactment of 
revenge in relation to the rape are transferred from female to male bodies. I argue that these narratives are phallocentric insofar as they afford certain male hermeneutic perspectives the status of objectivity, an attribution complemented by certain narrational techniques that Livy and Shakespeare employ.

In chapter three, I analyse the function of Lucretia's suicide within Livy's and Shakespeare's narratives, also citing other narratives wherein violence, or metamorphic mutilation, is waged post-rape upon the body of the raped character. In consultation with Bal's assertion that the association of suicide and rape in certain narratives "conveys the idea that the victim is responsible for her own destruction" (100), I argue that Lucretia's suicide functions, in Livy's and Shakespeare's narratives, as a form of self-punishment which references historically specific correlations between female unchastity and socio-political calamity.

In chapter four my focus shifts to J.M. Coetzee's novel In the Heart of the Country. Herein, I contrast Magda's "frustrated desire for human community" (Gallagher 97) with the relationships between self and community that Livy and Shakespeare portray. I argue that Magda longs for communion with those whom (and that which) surrounds her, that she tries "to make contact on a human plane and perhaps even a plane of love with two people, one man and one woman with whom she has been brought up together in a relation of master and slave" (Interview with Folke Rhedin 7). However, I also argue that Magda's efforts are thwarted because she persistently re-asserts the ideology of "master/slave discourse" (Wohlpart 221). As Coetzee puts it, Magda fails "because a mere effort of the will is not enough to overcome centuries of cultural and spiritual deformation" (Interview with Folke Rhedin 7). This chapter forms a comparative counterpoint to much of what I discuss in chapter one. Livy and Shakespeare portray rape as objectifiable; their characters and narrators perceive rape in the same terms ${ }^{3}$ as each other, an indication of synthesised perception which suggests "mutuality, community, union" $(O E D) .{ }^{4}$ Coetzee's novel, in contrast, suggests that "the relation between individual experience and reality [ . .] is highly problematic" (Michael Vaughan qtd. in Watson 384). Neither Magda nor the reader are able to know whether other intradiegetic characters (for example, Hendrik) perceive the rape in any way similar to the way in which Magda describes it in the course of her narration. Narratorial omniscience is explored in Coetzee's novel as a way in which Magda imposes her

\footnotetext{
${ }^{3}$ That is to say, as the same sort of event, expressing the same meaning.

${ }^{4}$ This phrase is taken from the $O E D$ definition of 'communion.'
} 
own stories upon others, rather than employed as a formal device that encourages readers to accept the objectifiability of that which it relates. Coetzee's novel thus subverts the idea that "ideas or beliefs" are shared by characters in the novel and asks whether it is possible or ethical to live in, or aspire to, "an ecstasy of communion" (Coetzee, In the Heart 53).

In chapter five, I extend my analysis of the ways in which Coetzee's novel portrays rape as something which is "never adequately 'objectifiable" " (Bal 100). Herein, I consider the factual inconsistencies and phrasal variations between Magda's accounts of the rape(s), and analyse Coetzee' choice to omit what he terms the "scene-setting and connective tissue that the traditional novel used to find necessary" (Doubling 59). I argue that the novel's inconsistencies support a portrayal of rape as something which may hold "incommensurate meanings" (MacKinnon is paraphrased in Rooney 90) for Magda herself. In this chapter I establish another way in which Coetzee's novel departs from the conventions espoused in Livy's and Shakespeare's narratives. In those narratives Lucretia's description of the rape functions testimonially, serving as evidence for the men to whom she 'testifies' of what MacKinnon terms "rape law's assumption that a single, objective state of affairs existed" (654). Lucretia's description of the rape also marks the point, in Livy's and Shakespeare's narrative, in which the prerogative to suffer for and to avenge rape is transferred from the raped woman to her kinsmen. ${ }^{5}$ Magda's description of rape, however, does not, I argue, serve a testimonial function; rather, her descriptions function as reflective "meditations" (Gallagher 82 ) in which she tries to make sense of the rape by exploring its potential meanings and taxonomical identities. Thus is her experience of the rape created and recreated (Gallagher 82) as she narrates it. The non-testimonial function of Magda's descriptions of rape is also suggested by the novel's thematization of others' apparent unwillingness to listen to her. She is not charged, as Lucretia is, with the task of presenting an account of the rape to others which will enable those others to express suffering, and/or enact revenge, in response: rather, Magda's 'meditates' on the subject of the rape in the face of what she describes as the world's apparent indifference to her.

In chapter six, I summarise a number of psychoanalytical theories which deal with victims' traumatic responses to rape. These theories posit a number of ways in which

\footnotetext{
${ }^{5}$ Lucretia might, quite rightly, be said to 'suffer' from the fatal wound she inflicts upon herself. However, her suicide predominantly functions in both Livy's and Shakespeare's narratives as a means by which she is removed from the story, thereby no longer 'existing' in the diegesis as a character who is capable of withstanding further harm. Her kinsmen, however, suffer the loss of her, interpret her rape as something which directly harms them, and go on to enact revenge in response to the rape, ostensibly suffering further in the course of the battle which thereby ensues.
} 
women's apparent consent or acquiescence to ongoing abuse might be explained. ${ }^{6} \mathrm{My}$ objective herein is not to psychoanalyse Magda, who - I recognise - is a literary character, termed by one critic "a mere trope" (Rody 163), rather than a living, breathing subject. Rather, I aim, by describing these theories, to argue that expressions of apparent consent need not necessarily be read as evidence of unmitigated acquiescence to abuse. If the tendency to read apparent consent as an indication of unmitigated acquiescence to abuse extends from the belief that 'true' rape victims react to ongoing rape by persistently, continuously, and unequivocably demonstrating non-consent, ${ }^{7}$ then - in order to suggest that other readings of apparent consent are plausible - a review of the relevant psychoanalytical literature is called for. My discussion in this chapter calls critical attention to the ways in which we interpret literary descriptions of violence, abuse, and victim response. As such, this chapter relates back to the analysis of literary violence that I conducted in chapter three.

\section{Conditions for Reading}

Froma Zeitlin argues that classical Greek and Roman narratives are sometimes afforded the status of authoritative catalogues of human experience, claiming that they are often treated as "a reservoir of powerful archetypal images which lay claim to some privileged truth about human nature" (123). Zeitlin adds that, in accordance with this conventional assignment of authority to narratives from both Greek and Roman antiquity,

We might think that the classical speaks directly to us that which, as Gadamer says, 'is preserved precisely because it signifies and interprets itself.' Yet we must remember that its survival is also predicated on its capacity to reproduce the cultural values required for its survival. (Zeitlin 123-24)

I interpret Zeitlin's use of the term 'capacity' to refer not to an internal or inherent power exercised by these narratives upon us so much as the capacity afforded to them by us: a power, once conferred, that encourages us to accept the logic of their conventions as natural and essential. As such, reading a classical text in the present becomes not just an act of

\footnotetext{
${ }^{6}$ Explained, that is to say, as traumatic response to undesired trauma, rather than as an indication that the victim does indeed want the abuse to continue.

${ }^{7}$ As, I contend, it does. See pages 27 and 124 of this thesis.
} 
perusing the literary past: if treated, as Emily Detmer-Goebel has suggested they sometimes are, as "cultural scripts for action" (82), a narrative " 'can, and does, become our production' " (Theweleit qtd. in Joshel 113). By comparing Livy and Shakespeare's narratives with Coetzee's I am not seeking to conclusively demonstrate the influence of one upon another, but to consider the extent to which the conventions of the former persist or are disrupted in the latter, and what the consequences of a repetition and confirmation of these conventions or, a deviation from these conventions - might be.

T.J. Cornell has written that Livy's accounts exemplify a tradition by which historical writing "was neither an authenticated official record nor an objective reconstruction, but rather an ideological construct, designed to control, to justify, and to inspire" (Cornell 58). Joshel adds that

$$
\begin{aligned}
& \text { Before he begins his historical narrative per se, Livy urges } \\
& \text { a particular kind of reading. His stories will proffer an array } \\
& \text { of subject positions, beliefs, and bodily practices. The reader } \\
& \text { should recognize and identify with them and should under- } \\
& \text { stand the consequences of assuming particular subject posit- } \\
& \text { ions. Bodily practices fit into a vision of building and collap- } \\
& \text { sing empire: some result in imperial power; others bring } \\
& \text { decadence and destruction. Thus, the question for us is not } \\
& \text { whether victims, villains, and heroes are fictional, but the } \\
& \text { way Livy tells their story, offering up a blueprint for his } \\
& \text { imperial present. (115) }
\end{aligned}
$$

Certainly, there are key differences to be noted between what Joshel describes as the instructional format of Livy's writings and the noted non-didacticism of Coetzee's fiction. Rita Barnard, to give an example of the latter, comments that "J.M. Coetzee's novels often leave the reader with uncomfortable, unanswerable questions" ("J.M. Coetzee" 199). Dodd's less favourable verdict is that Coetzee's writing in no way explains "how one might effect any change in the balance of power either in the South African context or elsewhere" (Power 77).

Notwithstanding the differences in degrees of didacticism that characterise the works of these two particular writers, I am interested to compare the different ways in which they 
approach what is fundamentally the same task: to provide narrative bases for the envisaging of how to transform communities. I will argue, for example, that Coetzee's 'play' with literary conventions results in a body of fiction that provokes readers to think through the complex project of forming more humane communities. Samuel Durrant shares my view that Coetzee's literature can indeed "offer a way of working through a collective history" (430) despite widespread criticism of his novels "for failing to represent the material conditions of apartheid, for their perceived 'revulsion' from history" (431).

I insist, throughout this thesis, on reading my selection of primary narratives as rape narratives; in doing so, it is not my intention to imply that this is the only way in which they 'ought' to be read, nor to dismiss as less significant the many other ways in which they are classified and the many other contexts in which they are studied. My questions are posed, simply, in the spirit of Richlin's insistence that "content is never arbitrary or trivial [. . .]. A text about rape may also be about something else, but it is still a text of rape" (159). 


\section{PART ONE}

Lucretia and the Sabine Women 


\section{CHAPTER ONE}

\section{Objectifiability}

"To see sad sights moves more than hear them told, / For then the eye interprets to the ear / The heavy motion that it doth behold" (Shakespeare, The Rape of Lucrece lines 1324-26).

One major way in which rape resists representation is its argued indistinguishability from (consensual) sex for those viewing it from the outside. ${ }^{8}$ Bal contends, for example, that rape is identifiable only in terms of how it is experienced internally by those involved. She argues that rape "cannot be visualised not only because 'decent' culture would not tolerate such representations of the act" (100) but because rape

is, physically, as well as psychologically, inner. Rape

takes place inside. In this sense, rape is by definition

imagined; it can exist only as experience and as mem-

ory, as image translated into signs, never adequately

'objectifiable.' (100)

I interpret Bal's use of the term 'inner' to connote the psychological and physiological 'territories' of one's self within which one conceives and perceives sensations which are

\footnotetext{
${ }^{8}$ That is to say, for those who occupy the subject position of neither ostensible rapist nor ostensibly raped person, either as a physically present, literal onlooker during the rape or in other ways (i.e. as a listener to or reader of later accounts, in fiction, testimony, or other forms, of rape). By 'occupy', I refer both to the positions allotted to characters within a diegesis, and to the position occupied (in a metaphorical sense) by a narrative's external readers (which is to say, that subject position / quasi-visual vantage point with which they are aligned via focalisation). By 'outside,' I mean the condition of being both a) 'outside' of the minds and bodies (or in Bal's terms, the psychology and physicality) of those involved in an ostensible rape, in the sense that one does not feel within one's own body the physiological sensations that occur within the bodies of those involved, nor think nor directly experience the thoughts that occur within the minds of those involved, and b) 'outside' of the lines of vision of those involved, so that one visually (or quasi-visually, for example via narrative focalisation) perceives the rape from a position other that occupied by those involved.
} 
imperceptible to others unless expressed via signs. ${ }^{9}$ I don't interpret her use of the term 'imagined' as a suggestion that rape is imaginary, but rather, read it as a way of arguing that the 'evidence' of rape's ontological status as experienced reality is constituted only in metaphysical terms, in the non-tangible, inner realms of physiological sensation, memory, and cognitive experience. An outside viewer may look directly at a non-violent rape but remain unable to conclusively say whether that sex act is consensual or not, so long as that outside viewer is unable to extra-sensorily perceive the rape victim's 'inner' feelings of nonconsent.

In visual art, the aforementioned optical indistinguishability between 'rape' and 'consensual sex act' is implied by exclusion: illustrations of rape narratives rarely depict sex acts en train, in literal terms. ${ }^{10}$ Paintings related to the rape of the Sabines show the Sabine women being forcefully carried away (see fig. 1 ): ${ }^{11}$ Lucretia is typically shown either with Tarquin in the moments after he invades her bedchamber (before the sex act transpires), ${ }^{12}$ or as she is poised to commit suicide (see fig. 2). ${ }^{13}$ For the viewer who defines rape as something that coincides with acts such as vaginal or anal penetration, these illustrations are parenthetical; they portray the events leading up to, or the aftermath of, an event that remains, conceptually, a bracketed gap.

\footnotetext{
${ }^{9}$ For example, gestures, sounds, or words that pertain to but are not unequivocable indexes for psychological and/or physiological sensations.

${ }^{10}$ By "sex acts en train, in literal terms" I mean penetrative sex acts (penetration of the anus or vagina by a penis or other appendage or instrument) in the process of occurring (at any stage from initial penetration to the cessation of penetration), or other variations of sexual activity (any kind of elicited or imposed physical contact with genitalia or other erogenous zones of the body) in the process of occurring. Clearly, the boundaries between what may be considered a sex act and what may not are non-concrete, and I do not attempt here to suggest a reductive nor exhaustive definition for the term 'sex act.' Rather, I mean to suggest that the paintings to which I refer in this portion of my argument avoid the explicit portrayal of a sex act to which they otherwise refer: they may, that is to say, include visual renditions of acts that may come under the heading of 'sex act' (or 'metaphoric sex act') but, predominantly, they suggest that the scenes they portray pre-empt or follow moments of sexual penetration or more explicit bodily contact that are not themselves painted on to the canvas.

${ }^{11}$ See also Peter Paul Rubens, The Rape of the Sabine Women (1635-40) and Luca Giordano, The Rape of the Sabine Women (1672-4).

${ }^{12}$ See also Titian Vecellio, The Rape of Lucretia (1568-71); Giuseppe Maria Crespi, Tarquin and Lucretia (1695-70); and Giambattista Tiepolo, Tarquin and Lucretia (1750).

${ }^{13}$ See also Albrecht Dürer, Suicide of Lucretia (1518); Paolo Veronese, Lucretia (1580-83); and Rembrandt van Rijn, Lucretia (1666).
} 


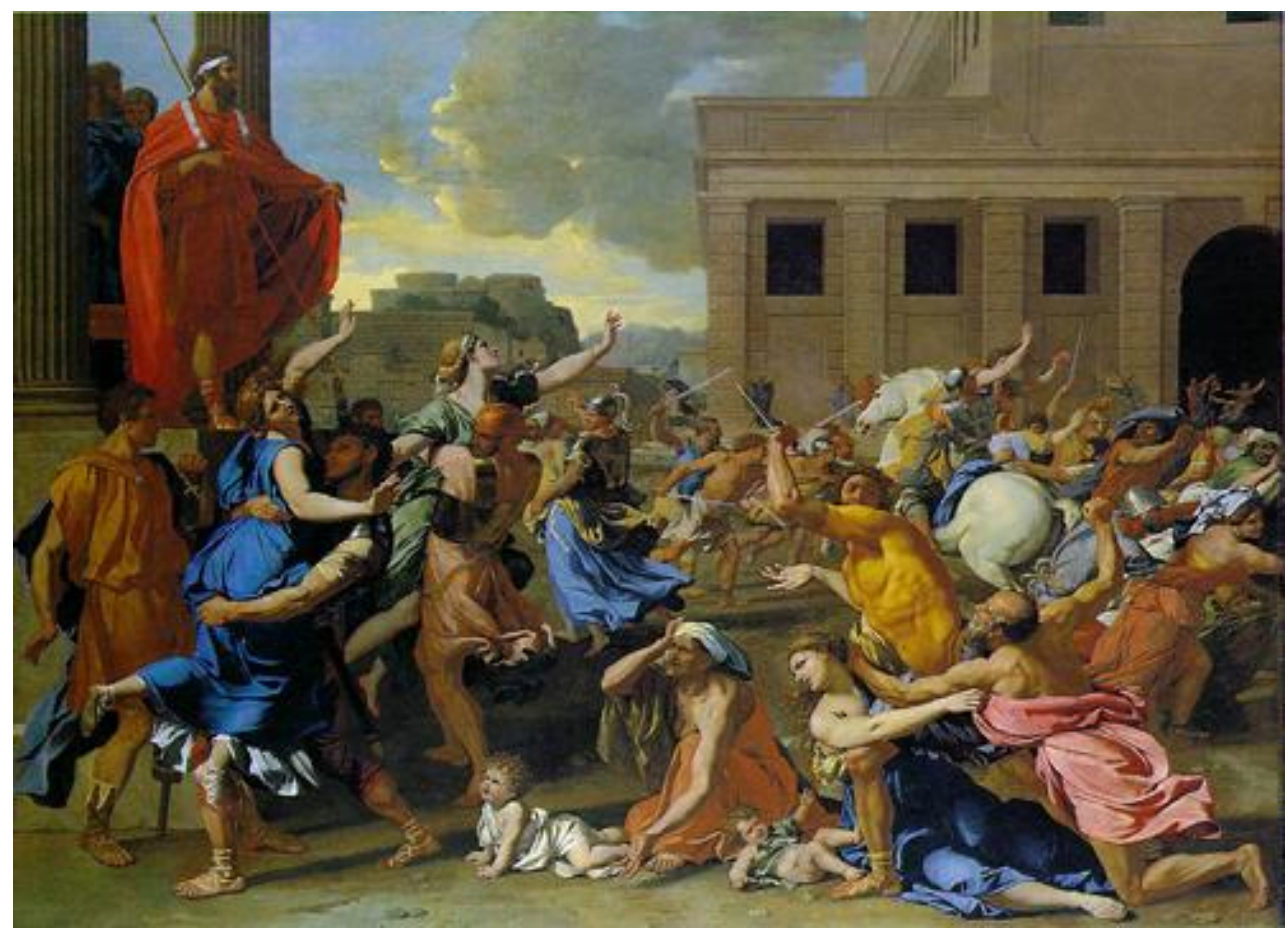

Fig. 1. Nicholas Poussin, The Rape of the Sabine Women (1635), The Metropolitan Museum of Art, New York, 14 Nov. 2009 http://www.etchings.com/erin/files/sabine.html

However, for viewers in earlier times and places these paintings may not have been considered parenthetic as such. To say that they parenthesise, rather than portray rape per se, is to assume an opinion on what rape definitively is, to assume that rape happens more essentially during activities other than those depicted in these paintings. It is to assume that rape happens not within but in between, for example, the motions of abduction and mourning.

This is not how rape was defined in ancient Rome - nor, even, in more recent times and places. ${ }^{14}$ If in "Western artistic traditions [...] rape has had a fraught relationship with articulation or representation" (L.V. Graham, "Reading" 439), it is partly because Western definitions of rape have been unstable and varied. Rape was commonly understood in ancient Rome as an offense against chastity. ${ }^{15}$ Art from (or art derived from) this period typically

\footnotetext{
14 For example, Emily Detmer-Goebel writes that only in sixteenth century English jurisprudence did " the definition of rape come to exclude abduction [. . .]. With benefit of hindsight, modern readers see this as the evolution of rape into a crime against a person (assault, as opposed to theft)" (76-7).

15 'Chastity' is not used here to solely connote a meaning synonymous with 'virginity,' but to connote the broader sense in which it was used in ancient Rome. Otto Kiefer notes that, in ancient Rome, getting married was (for a woman) considered a form of entering into, rather than graduating from, chastity. "Originally," he
} 


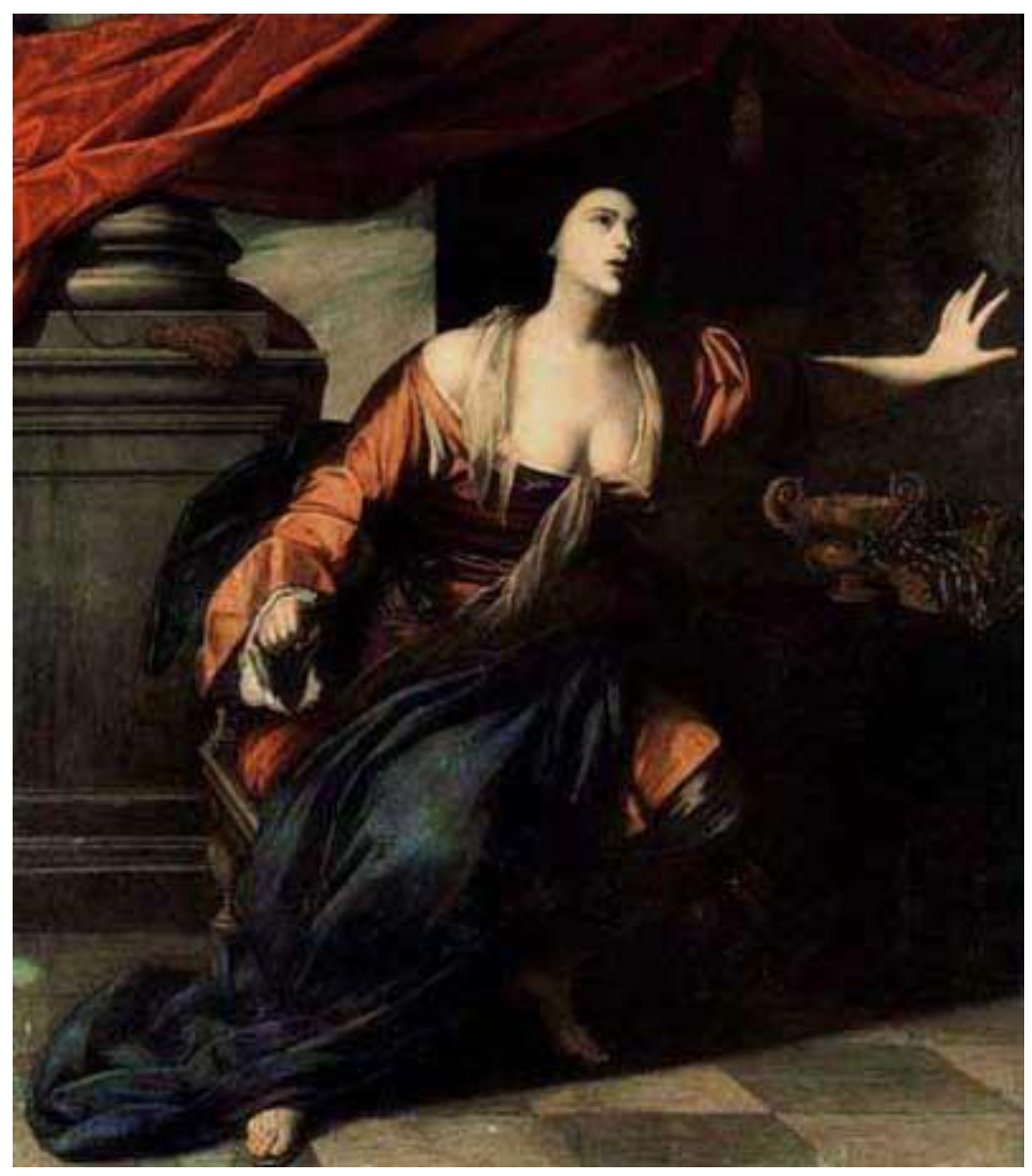

Fig 2: Artemisia Gentileschi, Lucretia (1642-43), Museo di Capodimonte, Naples, 14 Nov. 2009 http://www.artemisia-gentileschi.com/lucretia1.html

writes, "perhaps, the husband's friends had intercourse with the bride first. According to Bachofen, this was a survival of the free prostitution which preceded marriage in primitive times [. . . 'the woman who is entering marriage must atone to the Mother Nature for violating her, and go through a period of free prostitution, in which she purchases the chastity of marriage by preliminary unchastity' " (Bachofen qtd. in Kiefer 21). The Encyclopaedia of Religion and Ethics notes of the Roman concept of chastity that "In the earliest period the concept of chastity seems to have been the avoidance of improper sexual relations, and implicitly, therefore, the absolute avoidance of all sexual relations if none of them was proper, e.g. in the case of a virgin" (Encyclopaedia of Religion and Ethics) but adds that Seneca's Controversiae later suggests that chastity also refers to " 'abstinence from all foul and obscene things' " (Encyclopaedia of Religion and Ethics). In general, chastity connoted feminine adherence to a broad range of what was considered chaste behaviour, including but not limited to the "exclusion of meretricious ornament," the "exclusion of excess or extravagance," the practice of "moderation, restraint," "purity of style, modesty" and abstinence from "unlawful sexual intercourse" $(O E D)$. 
represents the concept of chastity as visible; ${ }^{16}$ paintings that depicted a woman mourning her pillaged chastity could thus be said to depict (not bracket) the Roman concept of rape. Furthermore, art that depicted chaste women being abducted could also be said to depict this understanding of rape. This is because in ancient Rome women (and their chastity) were considered the property of certain $\operatorname{men}^{17}$ (for example, a woman's father or husband), and their abduction therefore was classified as a crime of theft. As Diane Wolfthal points out, the component of theft was more essential to this definition of rape than sexual activity (that 'in between' discussed in the previous paragraph). As Wolfthal explains, in The Rape of the Sabine Women Poussin illustrates

the Roman concept of raptus, which was quite different from the modern definition of rape. In ancient Rome, raptus meant 'carrying off by force;' it was a crime of property and included thefts of all kinds. If violence was a necessary component of the crime, sexual intercourse was not." (Wolfthal 9) ${ }^{18}$

\footnotetext{
${ }^{16}$ For example, in Shakespeare's Rape of Lucrece, the narrator's description of Lucrece implies that her virtuous character is as visible - and, as unequivocable - as her physical beauty. Lucretia is described as that "Roman dame, / Within whose face Beauty and Virtue strivèd / Which of them should underprop her fame. / When Virtue bragged, Beauty would blush for shame; / When Beauty boasted blushes, in despite / Virtue would stain that o'er with silver white. / [ . . . . . . . . ] / This heraldry in Lucrece' face was seen, / Argued by Beauty's red and Virtue's white: / $[\ldots \ldots \ldots \ldots \ldots \ldots]$ / This silent war of lilies and of roses / Which Tarquin viewed in her fair face's field" (lines 51-6, 64-5, 71-2). Chastity (or the lack of it) was also portrayed as being visible in a woman's actions; this is the premise that makes the "chastity contest" (Jed 7) possible at the outset of the Lucretia story. In Livy's version, Collatinus proposes the guidelines for the contest using the terminology of sight, declaring that " 'the surest test' " of each wife's chastity will be 'What we see of the behaviour of each on the unexpected arrival of her husband" "(65). The other men's wives are found to be unchaste because they are discovered "in feasting and luxury with their acquaintances;" (66) Lucretia is credited with being the most chaste because she is found "sitting at her wool work in the hall, late at night, with her maids busy round her" (66).

${ }^{17}$ Lois E. Bueler also argues that, in ancient Rome as well as in Renaissance England, "women's sexuality was the property of men. The unmarried woman was the property of her father or his patriarchal surrogate, her virginity an expression of her filial duty to her father. The marriage contract transferred sexual rights to her husband, so that her sexual performance became an expression of her obedience to her husband" (38). Holt N. Parker argues that "A Roman woman existed legally only in relation to a man" (573) and that this was based upon on the idea that "To control women and their sexuality was to control the state" (588). Evelyn Gajowski adds that "The construct of marriage as a male-centered institution - one that is concerned with male control of female sexuality and the female procreative process, or, as anthropologist Gayle Rubin puts it, 'the traffic in women' (1975) - has been with us since the origin of patriarchal cultures [. . .]. A woman brings her chastity to marriage; she gives this to a man; he possesses her and her virtue [. . .] the institution of patriarchal marriage makes a husband's honor depend upon his wife's chastity" (64-65).

${ }^{18}$ It is important to note here that this does not confirm that sexual intercourse did not 'really' happen in the course of Roman rapes, or that it did not, perhaps, comprise for raped women a major component of their violation. The first few lines of chapter 9 in book I of Livy's History of Rome make explicit that the point of
} 
When, thus, I talk about Roman narratives not depicting rape, I mean in fact that their portrayals of rape correspond to a socio-historically specific definition of rape.

These paintings, depicting raptus, correspondingly portray the damage of rape as something which is experienced by parties other than the raped person herself, or imply that the damage of rape she experiences is a mere addendum to the damage perceived by others (she suffers the 'boomerang' injury of being devalued as wife or potential wife, because her husband or father understands her chastity to have been damaged or destroyed by the rape). Lucretia suffers because the rape devalues her in the eyes of others; by implication, we cannot be sure whether any harm, or what kind of harm, might have been suffered by her - as a woman forced to engage against her will in a sex act - were she not deemed chaste, nor her chastity deemed so valuable to certain key players (which is to say, certain powerful male figures in her diegesis), and thus damageable / destroyable by raptus. The concept of raptus, and portrayals of raptus in visual art, provide little insight upon what other kind of harm (besides that which pertains to the concept of chastity) might be caused to a woman forced to engage in a sex act she does not want. Thus, even paintings that positivistically render the concept of raptus visible imply, to me, the "fraught relationship" that certain ostensible components of a victim' $s^{19}$ experience of the harm of rape - which is to say, the experience of effects other than a reflected devaluation of oneself in other's eyes - has had to “articulation or representation" (L.V. Graham, "Reading” 439).

What are the alternatives, for a representation of rape that ostensibly sets out to portray other effects of rape, as discussed above? In what other way(s) might rape be represented, so as to represent those components of a victim's experience which, I claim, have been absent from previous representations? One tempting answer to these questions goes something like the following: in order to better represent victim-based experiences of rape, narratives ought to more explicitly describe the sex acts ${ }^{20}$ involved in a rape - for example, the psychological processes of non-consent, or the physiological sensations of repulsion - in order to attempt to render these aspects of rape more 'present' in the narrative

raping the Sabines was to facilitate sexual reproduction: the Roman State "threatened to last for only one generation," we are told, "since through the absence of women there was no hope of offspring" (12). But these are texts that highlight other parts of rape that would have experienced (by certain people) as offensive: the experience of losing one's woman (wife or daughter) through abduction, or having one's woman (wife or daughter) become (or be thought, as per popular convention) valueless through the loss of her chastity, would have conventionally been, for example, offensive to that woman's husband and/or father, in this context.

${ }^{19} \mathrm{I}$ am referring here to the person who is raped, rather than her husband or guardian; in the Roman narratives I look at, these men are credited as principle 'victims' of rape.

${ }^{20}$ For example, as described in footnote 10 on page 19 of this thesis. 
discourse. I argue, however, that the task of creating rape narratives that attend to victimbased experiences of rape is not a matter of simply describing physiological aspects of rape or 'inner' non-consent more explicitly; attempts to more explicitly portray rape in this manner may result in a number of effects other than the clearer rendering of harm felt by a raped person and/or the illustration of how "Rape takes place inside" (Bal 100).

In literary narratives, even apparently indexical representations of 'manifested aversion' on the raped person's body - descriptions, for example, of contorted facial expressions, of turning away, or of shaking with fear - are substitutive and equivocal signs for rape that falsely lend a rape scene the semblance of seeability, as though it could inarguably be understood as rape by anyone looking at it from the outside. These details, however, do not in fact render rape an objectifiable sight. They can indicate a source of pain or distress other than non-consensuality; rape can happen without them; and, moreover, they have sometimes been deployed in rape narratives to connote rape's antithesis, consensual sex. In "The Art of Love" - to give an example of this last convention - Ovid argues that women's protestations ought not to be read as reliable indications of unwillingness. Quite to the contrary, he contends that

it's force that women want, They love refusing what they long to grant.

She who by love's swift onslaught is undone,

Rejoices in the infamy she's won:

Who might have yielded, but retreats intact,

Though feigning joy, is sorry for her act.

(105; I, lines 673-78).

According to Ovid, then, manifestations of resistance in narratives are potentially as suggestive of eroticised (and, he argues, consensual) play-violation as they are of rape (understood as unwanted sex). It should be noted here that I don't intend, in the course of this argument, to rob representative power from real-life expressions of resistance to rape, to insist that they mean nothing; I am arguing, rather, that descriptions of physical resistance to rape in literary narratives have frequently functioned both to eroticise terror, discomfort, and unwillingness and to make outwardly manifest resistance seem requisite to the experience of 'genuine' rape. 
The former effect suggests a role for rape as erotic pursuit. The latter threatens to compromise the authority of rape accusations made by people who are judged not to have made an adequate 'show' of non-consensuality during the event or who, at least, cannot prove that they did. This - the proof of protestation routinely expected of raped persons who press charges $^{21}$ - recalls the dynamics that allowed South Africa's security police to (almost) lawfully torture prisoners in Johannesburg's Vorster Square. In "Into The Dark Chamber: The Writer and the South African State" Coetzee describes these circumstances, arguing that

the rigmarole of due process, which requires the prisoner to accuse his torturers and produce witnesses, makes it futile to proceed against the police unless the latter have been exceptionally careless. What the prisoner in effect knows, what the police know he knows, is that he is helpless against whatever they choose to do to him.

Rape victims are frequently placed in a position akin to the situation of the prisoner described by Coetzee above: because visible proof of rape is almost always impossible to provide, there is little hope of one's allegations of rape being believed. Narratives that suggest rape's visibility - for example, by providing explicit descriptions of sex acts that presume to make victim-based rape experience more objectifiably present in a narrative - effectively support the conventional logic that one ought to be able to perceive rape unequivocably, or to provide visible evidence of having been raped.

Additionally, the 'no means yes' convention popularised by some rape narratives ${ }^{22}$ would suggest that, even if a rape victim were able to provide manifest proof of resistance, this resistance may not be taken literally nor, thus, believed. This is why - as Amy Richlin

\footnotetext{
${ }^{21}$ Refer to page 124 of this thesis.

${ }^{22}$ In Images of Rape: The 'Heroic' Tradition and its Alternatives Diane Wolfthal contends that aestheticised descriptions of discomfort, embarrassment, and fear in rape narratives have encouraged perceptions of violent sex as erotically alluring. She describes how "In ancient Greece, "Several red-figure vases juxtapose the theme of 'heroic' rape [the rape of mortals by gods] with scenes of everyday courting [. . . Especially if a scene of 'heroic' rape appears on a symposium vase, it may well have served an erotic function" (21). "In ancient Rome," she continues, "'heroic' rapes continued to stimulate sexual activity" (21). By the Renaissance era, she writes, "aristocratic patrons, in search of an erotic theme from antiquity, often preferred one in which the woman was unwilling. As a result [. . .] sex was linked to violence, a taste that is, sadly, still with us today" (22). MacKinnon echoes Wolfthal's latter sentiment by arguing that "force and desire are not mutually exclusive. So long as dominance is eroticized, they never will be" (650).
} 
argues - the 'no means yes' convention so significantly compounds rape's extant invisibility: it inverts, effectively erasing, the referents of women's words and actions. Richlin points out, for example, that in the passage cited from Ovid above

Women's emotions are consistently unreal .... - 'unwilling' (674) must describe a feigned emotion; 'naughtiness' (676) must be feigned scolding as in 665; even their facial expressions are artificial (678) .... The deletion of woman's voice here is even more thorough than in the tale of Philomela. $(168-69)^{23}$

It is my contention that the formation of more just rape-related jurisprudence must be preceded by an understanding of rape's 'innerness' and the corresponding difficulty for the raped person of proving resistance. Failure to recognise that rape "takes place inside" (Bal 100) would seem to place raped people in a situation whereby they are required to provide proof of manifest resistance that, in turn - as per popular convention - may or may not be taken literally as evidence of genuine non-consent. The task of popularising a greater social understanding of rape's innerness is not unrelated to the study of how rape is and has been conceptualised in literature. Certainly, a critical examination of the elaborate ways in which rape has been made to seem objectifiable in literature goes some way towards showing that rape cannot indeed simply be 'seen' from a "point-of-viewless" (Rooney 89) perspective. To demonstrate that representations of rape are always inflected by perspectival bias substantiates the call for a rethinking of rape-related "legal process as one involving a choice between incommensurate meanings rather than one of uncovering a (temporarily hidden) fact, the Truth" (MacKinnon is paraphrased in Rooney 90).

Barbara Herrnstein Smith has written that our experience (hermeneutic and evaluative) of a literary work

depends upon what might be called the psychological 'set' of our encounter with it: not the 'setting' of the work or, in the narrow sense, its context, but rather the nature and pot-

\footnotetext{
${ }^{23}$ In Greek mythology, Tereus cut out Philomela's tongue after raping her so that she would not be able to tell anyone that he had raped her. (Ovid 190; VI, 539-558).
} 
ency of our own assumptions, expectations, capacities, and

interests with respect to it. (10)

This idea might be applied both to someone reading a rape narrative and, more loosely speaking, to the readers portrayed within rape narratives: those characters within a diegesis, that is, who react to or 'read' the rape situation, termed "internal viewer[s] (or reader[s])"24 by Alison R. Sharrock in her article "Looking at Looking: Can You Resist a Reading?"25 It is largely through these internal readings that rape comes to exist in these narratives for external readers. ${ }^{26}$ For example, rape is framed in Shakespeare's poem The Rape of Lucrece by the internal readings of Tarquin and Lucrece. That is to say, our understanding that a rape occurs in the poem is heavily dependent on the narrative's inclusion of extensive access to the thoughts of Tarquin and Lucrece, whose monologues tell us that something called rape occurs, and also define for us what they mean by the word rape: the rape is bracketed beforehand by Tarquin's conflicted musings towards the rape as an abuse he is about to commit and, afterward, by Lucretia's woeful lamentations towards the rape as the experience during which her chastity was ruined. ${ }^{27}$

By portraying the rape as explicitly pre-meditated by Tarquin, Shakespeare's narration informs external readers in advance that a rape will occur. For example, we are informed by Tarquin's thoughts-made-manifest that the upcoming confrontation is going to be about his forcing Lucrece to comply with his will. ${ }^{28}$ After lighting a torch Tarquin states, " "As from this cold flint I enforced this fire, / So Lucrece must I force to my desire' " (181-82). Tarquin feels

\footnotetext{
${ }^{24}$ Henceforth I'm going to use Sharrock's second term ('internal reader,' rather than 'internal viewer') to refer to readerly characters in the narratives with which I am concerned. The term 'viewer' runs the risk of suggesting that rape can be readily, visually apprehended by onlookers; this implication may compromise my wish to attend to the complexities of beholding rape. Where I am paraphrasing or referring to a passage in which Sharrock has used the term 'internal viewer,' I will preserve her usage.

${ }^{25}$ As examples of internal readers in written narratives Sharrock lists "the internal audiences of plays within plays [. . .] eavesdroppers and others in New Comedy [. . .] the chorus in tragedy [. . .] [and] the addressee in satire, and even more explicitly, in didactic poetry" (265).

${ }^{26}$ The distinction between internal and external readers has been made in reader-response literary criticism, functioning as a broad but useful distinction. Sharrock points out that literary critics such as Wayne Booth and Wolfgang Iser "make more or less precise distinctions between implied readers internal to the text and real or external readers (however many further divisions they may make within each category)." (290).

${ }^{27}$ Tarquin voices his inner debate prior to entering Lucrece's bedchamber (181-2, 190-245, 253-80, 330-36, 348-57); these thoughts inform external readers that he will proceed with his plan to have sex with Lucrece despite his profound sense that this plan is, for many reasons, despicable. Prior to the sex act, Lucrece voices her non-consent in a lengthy speech directed at Tarquin (575-666); afterwards, she expresses her contempt for what has transpired over the course of several stanzas (764-1036, 1044-78, 1121-48, 1156-1211).

${ }^{28}$ Unless, that is to say, Lucrece consents to his demands. Since Lucrece's impeccable chastity has been established in "The Argument" (Shakespeare 149) - wherein she was designated the winner of the "chastity contest" (Jed 7) - this situation never seems likely to occur.
} 
that he " 'must deflower'" (348), and communicates to the reader an idea of how destructive this event is going to be for its victim, declaring

'Lucrece' [ . . ] 'this night I must enjoy thee.

If thou deny, then force must work my way;

For in thy bed I purpose to destroy thee.' (512-14)

Tarquin's premeditations help to alleviate the representative onus that might otherwise be borne principally by the sex scene. Without Tarquin's explicative preamble, there might be room for some interpretive ambiguity regarding what motivated this act and how we are to understand its significance; instead, Shakespeare's narration elaborately spells out the manner in which the event is planned and understood by the perpetrating actor.

Livy's version of the Lucretia story, though far more brief, sets up the rape as similarly premeditated, and determines its meaning (the destruction of Lucretia's chastity) in advance: after the "chastity contest" (Jed 7), Livy's narrator informs us that Tarquin "formed the vile project of effecting her dishonour" (66). The lead-up to the rape scene in both Shakespeare's and Livy's versions thus serves a function similar to some captions surrounding an illustration of the rape of the Sabine women in the 1758 edition of Cesare Ripa's Iconologia. This picture, Wolfthal writes, is

Accompanied by two sets of verse that frame the interpretation of the image for the reader ... the print shows in the middle ground the Romans' violent seizure of the Sabines .... Without the verses, the viewer might feel anguish for the Sabine women, but the text indicates a different, 'proper' reaction. (28)

The 'proper' reading of the upcoming event provided by Tarquin in The Rape of Lucrece tells us that we should brace ourselves for anguish, that this is going to be a destructive rape, as opposed to the supposedly 'productive' rape of the Sabines. ${ }^{29}$

\footnotetext{
29 The latter rape is commonly interpreted, by its internal readers, as being 'for the best;' such is the case with the internal readings provided by the verses referred to by Wolfthal above, which tell readers that " 'The rape of the Sabines eliminated unhappy wars; / the barbaric theft brought about happy results [. . .]. The Sabines' rape, one must concede, / With the Romans peace did breed" " (28).
} 
Thus Livy's tale of Lucretia, and Shakespeare's poem, define in advance what (their) rape is going to be: a confrontation between lust (evil) and chastity (good) in which tragically - lust is likely to triumph. Accordingly, little anatomical description of a sex act is required to alert the external reader that the anticipated rape is happening and that it is bad; not having been set up as a sexual or bodily encounter so much as a duel of values, sexual and/or bodily description are not needed to deliver upon what the rape has been foreseen to entail. Livy indicates the 'moment' of the rape with only the curt and abstract statement that Tarquin's "lust triumphed over her [Lucretia's] inflexible chastity" (66). Shakespeare's description of the rape scene is longer but similarly metaphoric, portraying not so much what is happening with the bodies of Tarquin and Lucretia, as the interplay of abstract concepts. In an act expressing the symbolic stamping out of Lucrece's flame of chastity ${ }^{30}$, Tarquin "sets his foot upon the light, / For light and lust are deadly enemies" (673-74). Tarquin and Lucrece are next refigured as animal embodiments of aggression and passivity, the narration telling us that "The wolf hath seized his prey, the poor lamb cries" (677). Finally the encounter is abstractly imagined as the soiling of a precious object, with the narrator lamenting that "prone lust should stain so pure a bed!" (684).

Nevertheless - despite, that is, the manner in which both Livy and Shakespeare describe the rape scene in abstract terms, as a collision of values, not telling us so much what it looked like as what it (supposedly) meant - Lucretia's remarks imply retrospectively that the rape was visible, and that, in the aftermath, its effects are also visible. Livy's Lucretia, for example, explains the rape to her husband in terms of the visible traces she claims it has left behind: "The marks of a stranger," she tells Collatinus, "are in your bed" (67). In Shakespeare's version, Lucrece blames the night - referred to as a "Vast sin-concealing chaos, nurse of blame, / Blind muffled bawd, dark harbour for defame!" (767-68) - for having hidden the rape from view, implying that, had it been daylight, the rape could have been unequivocably seen (as rape) by an onlooker. It is only because Collatinus is away, and

\footnotetext{
${ }^{30}$ The association of fire and chastity here recalls the ancient Roman cult of Vesta, in which a sacred flame was tended by women known as the Vestal virgins. Susan G. Bell notes that, in ancient Rome, "Vesta, the Roman goddess of fire, was served by six priestesses known as the vestal virgins, whose main duty was to keep a sacred flame continually alight. If the flame were extinguished, immediate calamity was thought to threaten the state" (41). "Woe," Robert Turcan adds, "to the virgins who let the flame go out: the chief priest would have them flogged until blood ran" (56). H. Parker explains the relevance of the Vestal virgins in relation to ancient Roman culture by noting that the control of woman's sexuality - including the safeguarding of chastity - was equated with the safeguarding of Rome itself. "The unpenetrated virgin" with whom the Vestal flame was associated, H. Parker writes, "and the well-regulated wife both embodied the city" (592) thus justifying the axiom that "Female sexuality under male control was the basis of and the paradigm for keeping society under control" (592).
} 
because the rape was hidden by the night, that Lucrece describes it as having been an unseen crime; her speech here does not dramatise the concept of rape's unseeability as imagined by Bal - as intrinsically inner, and "never adequately objectifiable" (100) - but laments its state of having been an objectifiable event concealed from (and not yet explained to) the principal victim (who, by the logic of this narrative, is Collatinus). Lucrece abhors the rape's concealment insofar as it constitutes a surreptitious harm done to her husband, crying

'O unseen shame! invisible disgrace!

O unfelt sore, crest-wounding, private scar!

Reproach is stamped in Collatinus' face, and Tarquin's eye may read the mot afar, How he in peace is wounded, not in war.

Alas, how many bear such shameful blows,

Which not themselves but he that gives them knows!' (827-33)

Some marked internal readings of the rape are offered here by Lucrece: her remarks indicate, for example, that the rape constitutes a disgraceful wound to Collatinus - more, perhaps, than it constitutes a wound to herself - and that Tarquin is conscious of having committed a violation. Describing why she is loathe to meet the daylight, she also reads the rape as having made her unchaste and complicit in her assailant's guilt. Pleading to a personified night, she begs

'Make me not object to the tell-tale Day:

The light will show, charactered in my brow,

The story of sweet chastity's decay,

The impious breach of holy wedlock vow.

Yea, the illiterate, that know not how

To cipher what is writ in learnèd books,

Will quote my loathsome trespass in my looks.'

(806-12) 
For the moment, the aspect of these two passages which most concerns me is the presumption - so long as light, and a witness, are on hand - that "a sexual encounter can be read objectively, from a 'point-of-viewless' perspective" (Rooney 89). When, in posting her letter to Collatinus, Lucrece mistakes the messenger's bashful countenance for a knowing glance, it is suggested that her belief in her shame's visibility may be exaggerated by paranoia: "She thought," the poem reads,

he blush'd, as knowing Tarquin's lust,

And blushing with him, wistly on him gazèd;

Her earnest eye did make him more amazèd;

The more she saw the blood in his cheeks replenish,

The more she thought he spied in her some blemish.

However, the underlying logic of Lucrece's argument (premised upon the notion that rape and its repercussions are objectively visible) is supported rather than discredited by the remainder of the narration. Shakespeare's omniscient narrator - besides being able to access the internal thoughts and motivations of Lucrece and Tarquin - appears to report events, as they happen, from a "nonsituated, universal standpoint" (MacKinnon 636). From this apparently unbiased standpoint, the narrator in Shakespeare's poem describes the rape as being visible to the entire world within which it occurs; though no human witnesses are on hand, the narrator characterises the environment (i.e. Lucrece's house and contents, the sun) as animate viewers of the rape scene. For instance, the narrator describes how surrounding doorways, weasels, the wind, and Lucretia's glove 'see' Tarquin as he approaches Lucrece's bedchamber, understand what he intends to do, and conspire to "make him stay" (323); undeterred, he continues on, whereupon the narrator instructs external readers to "Look, as the fair and fiery-pointed sun, / Rushing from behind a cloud, bereaves our sight" (372-73). The manner in which events are made to seem objectively viewable here is almost comical: Shakespeare's narrator literally conveys the impression that the rape ${ }^{31}$ can be perceived by objects. Livy's narration is not prosopopoeic but conveys a similar impression of "distanced

\footnotetext{
${ }^{31}$ To a contemporary reader, Tarquin's approach may not be considered part of the rape per se but part of the lead-up to the rape. However, his negotiation of the corridors leading into Lucretia's chamber can be read as symbolic of the rape itself; his various encounters here (with doors, locks, the glove, etc.) suggest precisely the confrontation between lust and chastity that 'rape' in this narrative is set up to mean.
} 
aperspectivity" (MacKinnon 658); the opening paragraph of the chapter in which Lucretia's rape is related suggests that the narrator occupies a sweepingly omniscient vantage point. ${ }^{32}$

Livy's and Shakespeare's use of omniscient narration conceals their privileging of particular perspectives upon rape by presenting their diegeses as though viewed 'from above' by impartial narrators. Their narrators seem to panoramically survey what is objectively viewable 'below;' external readers are dissuaded from recognising that events are being narrated from "a specific position" (MacKinnon 658) that "creates the reality it apprehends" (MacKinnon 636). Livy and Shakespeare's narrators create the sense that rape is an objectively visible spectacle by seeming to survey a world whose inhabitants can visually apprehend rape; because of this, their narratives comprise strong arguments in defense of rape's objectifiability. MacKinnon insists that the significance of suggested visibility as a means to objective knowledge should not be overlooked. She argues that

since Plato's cave, visual metaphors for knowing have been central to Western theories of knowledge, the visual sense prioritized as a mode of verification. The relationship between visual appropriation and objectification is now only beginning to be explored. (footnote 4, 636-37)

Far from being an impartial position, the assumption of rape's objective visibility that these narratives support is ideologically charged. Translated into a legal context, these narratorial positions are equatable to "rape law's assumption that a single, objective state of affairs existed, one which merely needs to be determined by evidence" (MacKinnon 654). This assumption, MacKinnon argues, evades recognition of rape's 'split reality:' the common scenario, that is, in which the experiences of those involved in an ostensible rape are incommensurable. As she points out,

Many women are raped by men who know the meaning

\footnotetext{
${ }^{32}$ In this paragraph the narrator surveys and evaluates Ardea, articulates the private economic desires of the Roman king, definitively declares what caused the war, and describes the living conditions of and collective inner feelings (towards their sovereign) of the Roman people, reading: "This people, who were at that time in possession of Ardea, were, considering the nature of their country and the age in which they lived, exceptionally wealthy. This circumstance really originated the war, for the Roman king was anxious to repair his own fortune [...] and also to conciliate his subjects by a distribution of the spoils of war. His tyranny had already produced disaffection, but what moved their special resentment was the way they had been so long kept by the king at manual and even servile labour" (Livy 65).
} 
of their acts to women and proceed anyway. But women are also violated every day by men who have no idea of the meaning of their acts to women. (652-53)

This 'split reality' is the starting point of rape trials, wherein the point is to determine whether or not a rape occurred. Operating from the tenet that all confirmed rape is criminal, rape trials generally end when a version of events is decided on - and effectively afforded the status of truth - by the authority of the court. Alternatively, instead of dramatising the 'split reality' that precedes a court's decision, Livy's and Shakespeare's Lucretia narratives never question that a rape occurred; as argued above, they portray rape as something pre-meditated and possible to unequivocably view. The text itself, in each of these narratives, narrated as though from an impartial perspective, seems to fulfil the role of evidence for that event which forms the central subject matter: each text functions as a sort of idealised testimony, isomorphic to the rape as it (supposedly, diegetically) objectifiably occurred. In both versions, Tarquin's and Lucretia's understandings of what occurs are fundamentally synchronised; furthermore, the prosopopoeic, environmental 'onlookers' also see and interpret the event in the same terms as raped and rapist. There is no contest of meaning staged between rapist and raped, no disputation of roles, and no suggestion of a viewpoint on reality outside of the all-encompassing omniscient scope of the narrating voice. In other words, these narratives seem to fulfill a role akin to the 'true version of events' that, MacKinnon argues, is the ambition of mainstream rape-related jurisprudence. Artistically, they accord with the "assumption that a single, objective state of affairs existed" (MacKinnon $654)$.

Given that their narrators seem to be endowed with an omniscient capability to narrate the 'true story' of rape - a power that would seem to exceed the cognitive ability of those who experience rape as 'split reality' - it is easy to understand why they might be treated as sources of wisdom about rape, as "a reservoir of powerful archetypal images which lay claim to some privileged truth about human nature" (Zeitlin 123). Whether or not it actually is or has been common practice for external readers to approach any narrative in this manner, the idea of referencing older rape narratives as procedural sourcebooks has certainly been dramatised within literature; Emily Detmer-Goebel argues that in Shakespeare's Titus Andronicus 
Aaron's knowledge of the classics incites the rape, but the same text fuels Titus's method for revenge. Thus, the texts of Lucrece and Philomela seem to operate as cultural scripts for action ... The play shows the men confused by the intersection of two different sources of authority: the real woman and the literary text. (83)

Detmer-Goebel notes that critics such as Richard Brucher and Gillian Murray Kendall, however, "read the references to classic stories of rape as in some way blinding" (83). I contend that the blinding function of these narratives when treated as "cultural scripts for action" is to effect, as it were, a sort of quasi-optical double-negative: treating rape as visible, they blind us to the idea of rape's unseeability, to its status as an experience that is "physically, as well as psychologically, inner" (100).

Livy and Shakespeare's narratives omit explicit suggestion of the idea of rape's split reality, or at least propose that, in narrative, the experience of rape can be representatively reconciled into an objectifiable whole. However, if they do seem to provide representations of rape as objectifiable event, they achieve this only by affording one point of view ${ }^{33}$ the status of objectivity. They do not approach the idea of sustained incommensurability of meaning between accuser and accused; nor even do they stage a debate over the rape's potential meanings premised on the assumption that a 'true meaning' can be reached, as in rape trials where

the legal problem has been to determine whose view of that meaning constitutes what really happened, as if what happened objectively exists to be objectively determined. (MacKinnon 652)

\footnotetext{
${ }^{33}$ The narration of Shakespeare's The Rape of Lucrece is not always focalised via the same metaphoric pair of eyes; for example, there is a passage in which we read about events as from Tarquin's vantage point (316-17 read that "by the light he [Tarquin] spies / Lucretia's glove" [the use of 'Lucretia' instead of 'Lucrece' here is Shakespeare's] ), and another where we seem to 'see' things as through Lucretia's maid's eyes (1217-18 read that "Poor Lucrece' cheeks unto her maid seem so / As winter meads when sun doth melt their snow"). When I use the term 'point of view' herein, thus, I am not referring to quasi-visual lines of sight, but to a figurative interpretation of the phrase to mean 'opinion upon' or 'hermeneutic understanding of.'
} 
Instead, a certain interpretation of the rape and its meaning is privileged in these narratives as if it were the only possible interpretation.

The privileged point of view in Shakespeare and Livy might be defined as that ostensibly held by certain, powerful male characters (for example, by Collatinus, Lucretia's father Spurius Lucretius, and/or Brutus). Within these diegeses, the authority of these (and certain other) particular men ${ }^{34}$ to diagnose what something means (more often than not by apprehending it visually) is presumed; it is fundamental, for example, to the logic of the "chastity contest" (Jed 7) with which the Lucretia story opens. In Livy, as the soldier's verbal debate over whose wife is most chaste grows heated, Collatinus suggests "that there was no need of words, it could in a few hours be ascertained how far his Lucretia was superior to all the rest" (65). His suggestion is that he and his company can resolve the debate by riding to Rome and looking at their wives. The implications here are twofold: that, firstly, the women's chastity (or lack thereof) is an objectifiable facet of their character, visibly perceptible on their skin, ${ }^{35}$ and/or, secondly, that these men's particular way of visually interpreting the women's behaviour will command the status of an objective assessment of character. Objectifiable reality, and reality as perceived by these men, exist interchangeably in these narratives: what they see in the women is also presented in these narratives as the unequivocable truth. In the wake of the "chastity contest" (Jed 7), these men's optical evaluations of female chastity assume further authority by informing the logic of the rest of the plot: in order for Lucretia to be rapable, that is, and for her rape to constitute a significant loss, she first has to be established as chaste by those whose meaning counts. And indeed, within the logic of these narratives, she is established as such: the men's interpretation of weaving as a chaste activity (versus socialising, the purportedly unchaste activity in which the other wives are apprehended) allows them to visually diagnose Lucretia as most chaste.

In the following chapter, I will explore the ways in which Livy's account of Lucretia and the Sabine women, and Shakespeare's The Rape of Lucrece, further express the theme of male ownership ${ }^{36}$ both thematically and in the way that they are narrated. In the guise of objective omniscience, certain privileged masculine perspectives 'own' the narration; the way that rape is understood (as raptus) relies on the concept that women are owned by men; and finally, because men are conceived of within these narratives as being the principal

\footnotetext{
${ }^{34}$ For example, the men who comprise Collatinus' co-judges in the "chastity contest" (Jed 7).

${ }^{35}$ Refer to footnote 16 on page 22 of this thesis.

${ }^{36}$ As will become clear in the proceeding sentences, my use of the word ownership is a (figuratively) loose one, but I think it will be a useful term; I want to draw parallels between the ways in which power is afforded to certain perspectives (and not others) both in the content and narratorial structures of these narratives.
} 
victims (however much by proxy) of rape, the relevant male characters also 'own' the prerogative to rape-related suffering (and, in consequence, also 'own' the right to execute revenge). 


\section{CHAPTER TWO}

\section{Ownership}

As discussed above, Livy and Shakespeare's narratives do not ask whether a rape occurred; however, the rapes they posit as indisputable events aren't portrayed as being implicitly criminal. That is to say, they transfer focus from the question of whether a rape occurred to the question of whether a rape was criminal. This shift in focus suggests that forcing women to have sex isn't in itself criminal, but that, rather, it only becomes a crime under certain circumstances; these circumstances, in Livy and Shakespeare's narratives of Roman rape, are decided upon by certain men.

Rape is only portrayed as criminal in these narratives when it constitutes a crime from certain male characters ${ }^{37}$ points of view. The logic of these narratives accords, thus, with Wolfthal's summary of Roman rape-related jurisprudence when she writes that "Roman law did not view the crime from the woman's point of view. Rather raptus was a crime against the woman's husband or guardian" $(9){ }^{38}$

The idea of raptus as a crime against a woman's kinsmen can be traced to the ancient Roman notion - a notion, incidentally, which has had currency in other times and places since - that women, and the domestic environments to which they were confined, were " 'receptacles of male honor' " (Julius Kirshner qtd. in Jed 11). By extending Kirshner's crude but appropriate metaphor, one can approximate an explanation of why a woman's chastity

\footnotetext{
${ }^{37}$ That is, when the majority of male characters (or those with most power) deem it to be criminal. Consensus is not always immediate, as in Livy's narrative of the Sabine women, wherein the fathers of the raped women raise "tearful complaints" against the Romans who, for their part, support Romulus' view that the rape of the Sabine women was non-criminal and indeed 'for the best' (Livy 13). In time, the Sabine parents are brought under the authority of their Roman neighbours; the narrator tells us that "Romulus came upon them with an army, and after a brief encounter taught them that anger is futile without strength" (14). Ultimately, via the intervention of the Sabine women (to be discussed later in this chapter) "the two nations were united into one state" (17), and the general attitude assumed by all was that the rape had been fundamentally opportune (17).

${ }^{38}$ I am not suggesting that I am able to define what form "the woman's point of view" assumed in ancient Rome; my argument is merely that we are being encouraged by these narratives to accept masculine vantage points as objective.
} 
was widely considered the measure of how desirable a vessel for male honour she could be: it was desirable to covet a beautiful container with an unbroken safety-seal which would not admit contaminates once entrusted with its contents. This is the logic that underwrites literary situations such as Livy's account of Verginia, in which "Verginia's fiancé Icilius [. . .] equates an assault on female chastity with violence done to male bodies" (Joshel 121). It also rationalises the idea that not all rape is criminal: for rape to be considered criminal by those invested in these narratives with the authority to do so, it has to be understood by those with authority as an offense against chastity. Otherwise, it is not a theft - not an owned vessel burgled and broken beyond repair - and therefore does not constitute the crime of raptus.

In both versions of the story, Lucretia does not accede to Tarquin's demands when he threatens her with death; she 'chooses' rape over death only when he threatens to kill her and her slave, place their bodies together in bed, and claim that he had caught and killed them committing adultery together. After making this threat, Shakespeare's Tarquin pleads with Lucrece that

'[. . . for thy husband and thy children's sake,

Tender my suit. Bequeath not to their lot

The shame that from them no device can take,

The blemish that will never be forgot [...].'

The logic by which Lucrece 'prefers' to be raped (rather than killed in a manner that would irreparably disgrace her husband) confirms that, by the logic of this story, her value as receptacle of male honour is greater than the value of her life in itself: defeat the former role, and the point of the latter is all but nil within this set of cultural circumstances. Shakespeare's narrator confirms this after the rape by informing external readers that "she hath lost a dearer thing than life" (687). Lucrece therefore waits to kill herself until she has summoned her husband and made a show to him of her innocence (though her protestations of guiltlessness do not, by her 'own' ${ }^{39}$ logic, excuse her from the death penalty that she carries out against herself).

\footnotetext{
${ }^{39}$ Coppelia Kahn has argued, "Given the stridently patriarchal ideology in which the character is coded, then, it is supremely pertinent to ask the question Mary Jacobus asks: 'Is there a woman in this text?' (1982: 117-41).
} 
The consequences of measuring rape's criminality solely in terms of the offense it poses to male-owned chastity are vast. This logic disqualifies from consideration as criminal all rapes in which chastity was not considered by a woman's kinsmen to be at stake; in other words, certain sex acts could be designated as unwanted by or forced upon a woman, but this designation would not in itself suffice to connote that the sex act had been criminally offensive. Indeed, in some cases, the capacity of a person to posit non-consent was often rendered moot. For instance, in ancient Rome, it wasn't considered 'culturally possible' to rape a slave, nor, thus, for the 'impossible rape' of a slave to be deemed criminal; as Richlin writes, "All slaves were, more or less, the sexual property of their owners" (Richlin 161). ${ }^{40}$ Wolfthal adds that, similarly, "the rape of prostitutes was often considered oxymoronic, since prostitutes were by definition common women, sexually available to all men" (2). The concept of male ownership strips female consent (and non-consent) of power; by the logic of these narratives, the will of the woman cannot be the thing offended against by rape, because, in these circumstances, it effectively doesn't exist. In this setting, a woman's consent is dictated by the terms of her ownership: thus, a slave's consent to sex with her master is deemed perpetual; a prostitute's consent to sex with all men is deemed perpetual; and a woman's consent to her husband is deemed perpetual (and, furthermore, exclusively available to him). This is expressed in Shakespeare's poem by Tarquin when he reasons that, even if Lucrece were to accede to his demands, he would still be committing the crime of raptus by overriding Collatinus' will; her own consent, or the lack of it, doesn't make or break the crime. As Tarquin puts it, preparing to approach Lucrece, “ 'I'll beg her love: but she is not her own'" (241).

Even when chastity was at stake, certain motivations for rape were commonly understood to excuse, to a large extent, its classification as properly criminal. In

\footnotetext{
Or, to paraphrase similar questions asked by Jonathan Goldberg about 'the Shakespearean text,' who or what speaks in the character we call Lucrece?" (28). Nancy J. Vickers contends, in answer to these questions, that Lucrece is a "voiceless creation of a rhetorical tradition through which the male gaze verbalizes itself" (paraphrased in Kahn 28). Whether or not Lucrece is considered a mouthpiece for "the male gaze," my use of the term 'own' her refers to the statements diegetically attributed to her in Shakespeare's narrative discourse.

${ }^{40}$ This is the logic that informs Livy's version of the near-rape and murder of Verginia, in which Appius Claudius, having "conceived a guilty passion" (188) for the betrothed Verginia, attempts to claim her (falsely) as one of his slaves, which would - as per the Roman notion of slaves as sexual property (Richlin 161) - entitle him to unlimited, and legal, sexual relations with her (whether or not she complied). During a whirlwind trial, presided over by Appius himself, Verginia's fiancé Icilius declares that he is "determined to have a chaste wife" (190) and thus will not marry her if she is first raped (190), seemingly indicating that, to him, the assault on Verginia's chastity would constitute a more serious crime than the assault on her own will or freedom. Ultimately Verginia is declared Appius' slave (192); in response to this decision Verginius kills his daughter, indicating to her that her death is preferable to the loss of her honour (193).
} 
Shakespeare's The Rape of Lucrece, for example, Tarquin lists a number of circumstances that would have justified his rape of Lucrece, stating that

'Had Collatinus killed my son or sire,

Or lain in ambush to betray my life,

Or were he not my dear friend, this desire

Might have excuse to work upon his wife;

As in revenge or quittal of such strife.'

(232-36)

These comments, too, are supported by the logic that Lucrece " "is not her own" " (241); as a vessel owned by Collatinus in which Collatinus' honour is stowed, she becomes the logical point of attack for anyone seeking to revenge anything ostensibly dishonourable that her husband might have done.

The literary repercussion of the logic by which rape is not automatically criminal is that narratives from this period which depict rape do not necessarily suggest that rape is tragic or criminal. The moral of these narratives, that is to say, was not, across the board, that 'rape is bad.' Rather, rape could be portrayed as a positive or even necessary event when it occurred within the confines of - or functioned to forcibly implement - socially acceptable methods of exchange. ${ }^{41}$ Even when the portrayal of women in these scenarios indicates that they experience rape as injurious, internal readings of that rape sometimes work to assert that the event was fundamentally opportune. Such is the case in Livy's version of the rape of the Sabine women.

MacKinnon argues that "To the extent possession is the point of sex, rape is sex with a woman who is not yours, unless the act is so as to make her yours" (644). Her argument accords with the logic of Roman law as it is portrayed in Livy's History of Rome, in which rape is non-criminal, and even 'for the best,' when it facilitates marriage; when, that is, it functions as an act by which men acquire (rather than despoil) women who are not (yet) theirs. In Livy's diegesis the rape of Lucretia is criminal because she already 'belongs' to Collatinus; without even the motivation of enmity towards her husband, Tarquin infringes upon Collatinus' ownership of Lucretia, thereby committing a serious crime. Similarly, in

\footnotetext{
${ }^{41}$ That is to say, methods of exchanging women that were considered socially acceptable within the diegetic world that a given narrative portrays.
} 
Livy, Appius' attempt to assert ownership over Verginia represents an unlawful attempt (veiled in false legitimacy) to steal her from her current owner, Verginius, and thereby rob from her the worth (her chastity) that has been promised to Icilius.

However, in Livy's account of the rape of the Sabine women, chastity is - by the logic outlined above - transferred rather than corrupted; as Richlin comments, "for the Sabine women, there is really nothing to be worried about, because they are getting married" (168). The narrative expresses the idea that raping women into marriage constituted a fundamentally acceptable social practice. As such, it might be grouped with other rape narratives that, according to Wolfthal, "construct marital relations as a form of justifiable sexual violence [. . .] [and] reinforced the idea of marriage as a form of violence against women" (15). Romulus ${ }^{, 42}$ reading of the event - which, as I shall argue below, is ascribed objectivity within the scheme of Livy's narrative - confirms both the idea that "when seduction fails, violence may be employed" (Wolfthal 26) and that the rape of the Sabines ought to be read as a fundamentally positive, productive event. In fact, Wolfthal adds, this story was commonly used to instruct new brides of "the traits that were expected of a new wife [. . . ] submissiveness to husband, sacrifice for family and country, and woman's role as peacemaker within the family (12). These are certainly the behavioural traits that Livy's Romulus - in a passage of narration that frequently renders his comments indistinguishable from those of the omniscient narrator - advises the raped women to assume.

The women are described in the wake of the rape as being "despondent and indignant" (13), but Romulus urges them to modify their behaviour. Or, more precisely, an instructional $^{43}$ passage follows the narrative's description of rape: the voice to whom some sentences within this passage might be attributed, however, is unclear. Sometimes the narration indicates that we are reading Romulus' voice recorded as free indirect discourse, ${ }^{44}$ as in the statement

Romulus [...] went round in person, and pointed out to them [the women] that it [the rape] was all owing to

\footnotetext{
${ }^{42}$ Romulus - who 'consoles' the women in the aftermath of their rape, and urges them to accept their new roles as Roman wives - also himself arranged for the mass rape to take place.

${ }^{43}$ The passage is instructional both for the Sabine women (it prescribes their reaction) and for external readers (it informs them of the 'proper' way in which to read the episode).

${ }^{44}$ Defined as the "Narrative representation of a character's thoughts and expressions without quotation marks or the usual addition of phrases like 'he thought' or 'she said' and without some grammatical markers [. . .]. In other words, the third-person narration freely adapts itself for the temporary indirect expression of a character's thoughts" (Abbott 190-1).
} 
the pride of their parents in denying right of intermarriage to their neighbours (13)

or when we learn that

he [Romulus] begged them [the women] to lay aside their feelings of resentment and give their affections to those whom fortune had made masters of their persons. (13)

However, other sentences in this passage, alternating with those cited above, contain no clear indication that they do not issue from the standpoint of Livy's omniscient narrator. Such is the case with an unattributed sentence stating that the women "would live in honourable wedlock, and share all their property and civil rights," (13) and the subsequent statement that "An injury had often led to reconciliation and love" (13).

By oscillating between phrases attributed to Romulus and other statements whose speaker cannot be confirmed, Livy's narration blurs the distinction between Romulus' personal reading of the rape and the seemingly official record of events dictated to us by the omniscient narrator. This interweaving of Romulus' voice with that of the omniscient narrator lends his reading of events an air of objective authority that is further confirmed by the language used within this passage. Note that, even within the sentences attributed to Romulus, the choice of words equates his reading not with opinion but with fact. The narrator, apparently reporting Romulus' speech by free indirect discourse, does not tell us that Romulus opined that the women's parents were responsible for violence done to their daughters; rather, we are informed that Romulus "pointed [this] out to them" (13) as though it were an objective fact to which the women's attention merely needed to be brought. Similarly, the idea that the rapists have been, by fortune, "made masters of their [victims'] persons" (13) is stated positivistically as fact; though contained within a sentence attributed to Romulus, this part of the syntactic equation is presented as a given. Romulus merely suggests that the women adjust their attitudes towards the 'fact' that they have been mastered.

As well as blurring the distinction between Romulus' interpretation of events and the narrator's seemingly authoritative diagnoses of meaning, this passage functions dually as 
instruction and prophecy. Grammatically, the interpretation of events proffered here dictates the women's reality: Romulus' 'recommendations' can also be read (and be read accurately) as narratorial description of what will occur in the upcoming narrative. In one instance, an imploratory tone is specified, when we are told that Romulus "begged" (13) the women to modify their behaviour. However, note that when we are told that the women "would live in honourable wedlock" (13), "would be the mothers of freemen" (13), and "would find their husbands all the more affectionate" (13), the verb 'would' does not serve a conditional ${ }^{45}$ function; rather, it operates in its capacity as the past-tense form of the verb 'will.' The verb use as such effectively deletes the relevancy of the Sabine women's responses; conditional phrasing would make these statements contingent upon the women's responses, ${ }^{46}$ but Livy's phrasing does not. In this sense, the majority of sentences in this passage suggest that the women are not simply being encouraged to respond in a certain way; rather, their future is being dictated to them. Romulus' perspective on events is subsumed into the authoritative declaration of how the women will behave; as completely as they are declared herein to have been mastered by their rapists, then, they are also mastered by the narration, and duly fall in line with the fate that has been anticipated for them. In a sense, thus, the Sabine women experience the overriding of their will twice in this narrative; first they are submitted to forcible sex, and subsequently their initial experience of the rape as injurious is overwritten by a summation of events, assigned the status of objectivity, that dictates an end to their unhappiness. Thus, it would seem, are they divested twice - both within the diegesis, and by virtue of the way Livy writes it - of the capacity to meaningfully express and/or revenge their own suffering.

Typically, the suffering associated with rape is expressed by foreign bodies ${ }^{47}$ within these Roman narratives; in the Lucretia stories, mourning and revenge are borne by the raped women's kinsmen, whereas in this episode suffering is removed from the Sabine women and expressed instead by their parents, who "went about in mourning garb, and tried by tearful complaints to rouse their countrymen to action" (13). The portrayal of suffering by proxy, as

\footnotetext{
45 The deployment of would in the conditional tense, especially to express counterfactual conditionals (for example, 'what would happen if something were different') tends to be more common in current usage.

${ }^{46}$ To write that they 'ought to live in honourable wedlock,' or that they 'could live in honourable wedlock,' for example, would implicate the women as actors upon whose actions the successful carrying out of these recommendations is contingent. The modality of 'ought' is instructional recommendation, that of 'could' is contingent possibility; both, thus, imply that the referee might choose to act otherwise. Livy's grammar herein expresses necessary, rather than contingent, modal logic; his sentences deliver the women, as it were, into a dictated fate, rather than implying that they may modify the possibility of these outcomes themselves.

${ }^{47}$ That is to say, by someone other than the person who was raped.
} 
such, repeatedly seems to effect an alteration in the meaning of that suffering, and a corresponding alteration in the means considered appropriate for its redressal. In the Lucretia story, for example, 'the suffering of the rape' comes to mean 'the suffering inflicted on the Roman people at large by the Tarquins;' suitable revenge, thus, carried out by the proxy sufferers, assumes the form of the overthrowing of the Tarquins and the subsequent instalment of a Republican government. This transfiguration of suffering is described as taking place under the instruction of Brutus; the narrator informs us that while several of the men "were moved by the father's deep distress" (67), Brutus commands that they "stop their tears and idle laments, and [. . .] act as men and Romans and take up arms against their insolent foes" (67). Similarly, the suffering borne by the Sabine women's parents assumes the form of a more general wrath towards the Romans. In doing so, it really only comes to replicate and extend the ill feeling that Rome's neighbours (including the Sabines) felt - even before the rape was orchestrated - towards "the [Roman] power so rapidly growing in their midst" (12). Accordingly, after participating in a series of assaults launched upon Rome, the Sabines are placated with a resolution that in fact does nothing to avenge the injury of the rape for the women (if that injury is understood to be an overriding of the Sabine women's will that led to their being subjected to forcible sex). Instead, the resolution only furthers Rome's success in the region, simultaneously placating the Sabine people by affording them a measure of power over their own, conquered, territory. As the narrator relates, "the two nations were united into one State, the royal power was shared between them, and the seat of government for both nations was Rome" (17). Incorporation into the very political entity which inspired their feelings of inferiority appears to solve, for the remaining Sabine population, the problem of power imbalance into which the suffering incurred by the rape of the Sabine women has been dissolved. Apart from leaving the women's personal suffering unaddressed - and dissolving it into another kind of suffering, expressed by other people this political incorporation is brought about in a manner that portrays the Sabine women as accepting responsibility both for instigating their own rapes and for, thus, causing instability in the region.

As violence erupts in the form of "renewed fighting in the middle of the valley" (16) between the Romans and Sabines, the narrator tells us that

the Sabine women, whose wrongs had led to the war, throwing off all womanish fears in their distress, went 
boldly into the midst of the flying missiles .... Running across the space between the two armies they tried to stop any further fighting and calm the excited passions by appealing to their fathers in the one army and their husbands in the other not to bring upon themselves a curse by staining their hands with the blood of a fatherin-law or a son-in-law [. . .]. 'If,' they cried, 'you are weary of these ties of kindred, these marriage-bonds, then turn your anger upon us; it is we who are the cause of the war, it is we who have wounded and slain our husbands and fathers. Better for us to perish.' (Livy 16-17) ${ }^{48}$

Thus, already alienated from expressing their suffering, Livy's women divest themselves here of the role of victim; or, rather, they establish themselves as 'deserving victims' upon whose bodies violence may justifiably be exercised. Positing themselves as the cause of the rape and war (due to which others are suffering), the women offer to the men a version of the story that relieves the Romans of the role of aggressor and therefore also relieves the Sabines of their feelings of enmity towards Rome. It is perhaps by means of the women's provision of this internal, retroactive reading that the conflict between the Sabines and the Romans is really resolved; by assuming responsibility for generating the crime and its after-effects, the women stop the men from being violent to each other by, quite literally, positioning their own female bodies as receptacles into which the men's violence can more expediently be poured. The bodies of these women are (re-)instated, that is, as sites upon which their kinsmen may appropriately dispose of their violence; effectively, the argument voiced through Livy's Sabine women is that violence against these women is more appropriate than violence between these men, and might even bring about peace.

Thus, although its internal readings frame Livy's rape of the Sabine women as a positive, rather than destructive, event - one in which the bodies of women are acceptably transferred rather than despoiled - this narrative is not dissimilar from the Lucretia narratives in terms of what it conceives of as the place of women in "visions of building and collapsing empires" (Joshel 113). These narratives, that is to say, envision the violation of women's

\footnotetext{
${ }^{48}$ This episode lends Romulus' / the narrator's earlier prophecies further authority; their assertion that the women would be happy, and submit to the authority of their new husbands, informs the logic of the women's intervention described above.
} 
bodies as something that precedes - and even, enacts - positive organisational change. Jed has noted that numerous "incidents of sexual offense registered in ancient historiography are necessary markers of change in a legal and political system" (3). The rape of the Sabine women effects fortuitous inter-marriage; the later intervention, in which the women position themselves in the line of fire, prompts the unification of the Sabine and Roman territories. As Wolfthal puts it, the rape of the Sabines "was necessary for the founding of Rome" (12), just as the rape of Lucretia is widely understood to have "precipitated the overthrow of hated monarchy and the founding of the Republic" (Joplin Ritual 52).

Once again, women's capacity to function as enablers of positive socio-political change depends, within these narratives, upon the concept that they are owned by men. Their efficacy as vessels for violence depends on their status as inferior, owned things; thus can violence be disposed of in them without the risk, for men, of retaliation. ${ }^{49}$ Conceiving of women as receptacles for both male honour and male violence also enforces the logic that rape has to be a crime against male-owned chastity in order for it to be a crime; since these narratives posit the acceptability of men who exercise forcible sex and inflict violence upon the bodies of the woman or women whom they own, the occurrence of forcible sex and/or inflicted violence as such, within these diegeses, doesn't necessarily imply the occurrence of a crime.

Even explored in detail, however, the theme of male ownership of women, I feel, leaves several questions about the logic of these narratives unanswered. If the Sabine women's invitation to violence makes sense because (in Livy's narrative) it establishes them as vessels for the harm that men would otherwise do to each other, the purpose of the violence that Lucretia wields upon herself in the aftermath of her rape is less clear. There seems to be more than one reason for the frequency, in these narratives, with which raped women become the targets of violence in the aftermath of their own rapes. Nor have I explored fully the social logic that justifies the decision of the Sabines and Lucretia to declare themselves guilty of their own rape. In the following section, I will explore other reasons whereby violence against women - including the violence that they wield against themselves by declaring themselves guilty of their own rape - is integral to the logic of raptus that Livy and Shakespeare's diegeses support.

\footnotetext{
${ }^{49}$ That is to say, of retaliation from the women upon whom violence is exercised.
} 


\section{CHAPTER THREE}

\section{Violence}

As I argued above, portrayals of rape that depict only abduction or suicide, rather than a sex act, might be interpreted as directly depicting raptus (theft of chastity). By interpreting these paintings as depicting this definition of rape directly, no inference of rape as a nonobjectifiable event is made. However, some critics argue that the narrative function of postrape violence against the raped women is to appease the latent anxiety of some male characters (for example, those in whom the responsibility for carrying out revenge has been vested) towards the fact that the rape was 'unseen.' Called upon to respond to the rape as an event of enormous significance, these particular men - the argument goes - duly desire it to be made, somehow, more visually manifest. If seeing is believing, then an explicit act of violence that "stands in for rape" (Richlin 165) has the effect of rendering the event more tangible and worthy of revenge (for those within the diegesis who react to it).

$\mathrm{Bal}$, however, argues that there is more to post-rape violence than the function of substitutive spectacle; that this violence so often serves to punish the raped person, Bal argues, "conveys the idea that the victim is responsible for her own destruction" (100). If post-rape, punitive violence waged against a raped person is read as a replica of of the rape itself, it serves, Bal argues, to suggest victim culpability. She suggests that post-rape violence is privileged by the internal readings provided in some portrayals of rape as a piece of evidence from which the crime can be inferred; it is as though, in a synecdochical ${ }^{50}$ manner, suicide is interpreted as a particle of forensic evidence that is intimately and directly

\footnotetext{
50 The distinction here between synecdoche and metonymy is important. Metonymical readings posit an association (between objects, concepts, ideas, etc.) that is arbitrary or at least non-essential $(O E D)$. Bal (100) suggests that the frequency with which "violence stands in for rape" (Richlin 165) encourages us to think of rape and suicide as sharing a more essentialised relationship. She argues that a visual representation of Lucretia's suicide (such as Rembrandt's 1664 painting) establishes suicide as part of rape. This accords with my earlier arguments in which, for example, abduction and suicide could be considered, themselves, representative of raptus. These readings are synecdochical because they interpret a representation to be depicting "whole for part or part for whole" $(O E D)$. In this chapter I will explore the logic behind the notion that suicide can be considered part of (and therefore ostensibly necessary to, or a natural extension of) rape.
} 
associated with rape. As she puts it, in the Lucretia stories "Self-murder becomes the detail that represents the entire process" (101-2).

Bal concentrates on discussing the rape-suicide relationship in renditions of the Lucretia story, but post-rape, punitive-style violence against raped women is also common in other rape narratives from antiquity. For example, the frequency with which such violence follows rape in narratives sourced from ancient Greece has led Richlin to argue that, cumulatively, these narratives suggest "an analogic or developmental relationship between rape and mutilation" (165). In many rape narratives sourced from Greek mythology, postrape violence assumes the form of metamorphosis forced upon the raped woman. This happens to some of Ovid's female characters in The Metamorphoses, such as Callisto, who is turned into a bear (54; II, lines 476-95), and Medusa, who is turned into a monster with serpents for hair (130-32; IV, 790-803). Notably, the violent metamorphoses that follow Ovid's rapes don't serve the purpose purported by critics above (to make the injury visible, after the fact, for those whose prerogative it is to enact revenge). Rather, transformative mutilation is typically inflicted against women in these diegeses by an onlooking deity who interprets the rape victim's ensuing pregnancy as evidence that she licentiously pursued adulterous sex, rather than as evidence that she has been raped. ${ }^{51}$ In these narratives, therefore, transformative mutilation serves, itself, as a form of revenge, rather than functioning as an allegorical spectacle of rape in response to which revenge is enacted.

Goddess-imposed, punitive post-rape transformation may seem quite different from Lucretia's post-rape suicide; they share the same purpose, however, in that they are intended to punish the raped women. That is to say, the rationale behind Lucretia's suicide - as portrayed by Livy and Shakespeare - is not dissimilar to the motivations that drive Juno and Pallas Athena to inflict harm; Lucretia, too, insists that she not be freed from the penalty for adultery, and loathes the idea that any women should look to her as an example of unchastity (Livy 67). Bal argues that the portrayal of self-punitive post-rape suicide - and, I would argue, of punitive metamorphosis - recapitulates "an aspect of the ideology of rape, in which the victim is conceived of as having committed the crime against herself" (99). Positing that "Rape is identified with suicide, not with murder as it should be," Bal asks "What, then, are

\footnotetext{
${ }^{51}$ Perceiving Callisto's pregnant belly some months after the rape, furious goddess Juno (whose husband Jove committed the rape) turns the raped woman into a bear. Juno refers to Callisto as "detested rival" (Ovid, Metamorphoses 53; II, 467) whose "guilty charms

[. . .] drew the Thunderer [Jove] from Juno's arms" (Ovid, Metamorphoses 53-4; II, 474-75). Medusa is turned into a monster by the onlooking goddess Pallas Athena, who "on the ravish'd virgin [Medusa] vengeance takes" (Ovid, Metamorphoses 132: IV, 800) by turning her hair into "hissing snakes" (Ovid, Metamorphoses 132: IV, 801).
} 
the semiotics of rape that we can infer from this displaced and misplaced, yet inevitable, suicide?" (99).

I contend that post-rape violence reflects a social logic by which woman is figured as the initiator of rape as much as she is the victim of it. As chaste object, a raped woman is rape's victim; however, she is imagined also to function as provocateur - she who attracts and inspires lust - and in this capacity she represents and is thought to be the origin of the lasciviousness that motivates criminal rape. ${ }^{52}$ Though her rapist may profess to be seized with the will to ravish her, she is identified as the instigator of this desire and is thus considered largely culpable for her own rape.

These ideas about what a woman is capable, as viewed object, of inspiring, involve a rather unstable distinction between beauty and chastity. The binary logic by which, in theory, beauty and chastity can be opposed would suggest that beauty is that which signifies female sexuality, or provokes men to sexually ravish a woman; by ancient Roman logic, beauty was in theory a dangerous and degraded thing for a woman to exude. Joshel argues, for example, that in the ancient Roman context 'the 'good' woman's threatening element is her attractiveness" (Joshel 120). Chastity - and the bodily symptoms and practices associated with it - was thought to be the means by which female sexuality was controlled or even castigated. By this logic, a woman could be blamed for having been perceived to exude sexually provocative beauty, given that this would signify the failure of her chaste practise to suppress all outward signs of provocation. This is the logic that underwrites Tarquin's accusation of Lucrece in Shakespeare's poem when he says to her that "the fault is thine" (482), and claims that

'Thy beauty hath ensared thee to this night,

Where thou with patience must my will abide,

My will that marks thee for thy earth's delight,

Which I to conquer sought with all my might;

But as reproof and reason beat it dead,

By thy bright beauty was it newly bred.'

\footnotetext{
${ }^{52}$ By this I connote those rapes which are classified as criminal in the ancient Roman world because they offend against chastity. The following argument, in which post-rape violence is related to Roman-designated criminal rapes, doesn't apply to Livy's rape of the Sabine women, whose rape is seen as non-criminal. In that narrative the rapists are not portrayed as having been motivated by or as having succumbed to inappropriate desire; rather, according to the internal readings provided in Livy's version, they acted in the manner necessary to secure Rome's future, transferring the women's chastity into their own possession by fundamentally acceptable means.
} 
The 'war' between beauty and chastity is also portrayed in Shakespeare's poem as being visibly manifest on Lucrece's face. The narrator tells us that Tarquin, looking at her, sees a face within which

\section{[...] Beauty and Virtue strivèd}

Which of them should underprop her fame.

When Virtue bragged, Beauty would blush for shame;

When Beauty boasted blushes, in despite

Virtue would stain that o'er with silver white.

But beauty, in that white intituled,

From Venus' doves, doth challenge that fair field.

Then Virtue claims from Beauty Beauty's red,

Which Virtue gave the golden age to gild

Their silver cheeks, and called it then their shield;

Teaching them thus to use it in the fight,

When shame assailed, the red should fence the white.

Often portrayed as inimical to each other, the distinction between beauty and chastity in rape narratives that abide by this logic, however, is hardly clear; be it attributed to the difficulty of differentiating between the apparently distinct physical signs of beauty and chastity, ${ }^{53}$ or to the established eroticism of the 'no means yes' convention, ${ }^{54}$ in these narratives rapists are said to have been provoked by their victim's chastity as often as they are said to have succumbed to her sexual alluring beauty. Either way, these narratives consistently designate the raped woman as hub of provocation. Livy's narrator reports that "Sextus Tarquin, inflamed by the beauty and exemplary purity of Lucretia, formed the vile

\footnotetext{
${ }^{53}$ Beauty is sometimes portrayed as evidence of chastity; other times, as I discuss above, it is posited as being inimical to chastity, as something indicative of that which chastity is meant to suppress.

${ }^{54}$ In keeping with the 'no means yes' convention (discussed earlier) whereby unwillingness is eroticised, it is by the contradictory logic of dissent's erotic appeal that chastity - though supposed to safeguard a woman's virtue (and, thereby, the honour of her father, betrothed, or husband) - becomes dangerously enticing, and is in fact, in Livy's and Shakespeare's Lucretia narratives, credited (along with the women's beauty) with the power to provoke its own violation.
} 
project of effecting her dishonour" (66). Shakespeare's narrator relates that "Haply that name of chaste unhapp'ly set / This bateless edge on his keen appetite" (8-9). Joshel argues that in Livy's Verginia and Lucretia narratives, "the beauty of each woman is marked and explains the rapists' actions. Lust seizes each man, as if desire originated outside him in beauty" (Joshel 120). Whether the rapist's actions are attributed to beauty or chastity, Livy's and Shakespeare's narratives of rape identify the raped woman as the carrier of signs which provoke her own rape.

Thus is chastity revealed not to be an actual source of power for these diegetic women; rather, the suggestion is that the women in these narratives have no control over what they signify and inspire as viewed objects (a term which best describes, I think, the role played by women in these narratives). Understood in these diegeses as a noble method of self-disciplinary control, chaste practise can be alternately interpreted as an instance of “Women's so-called power [which] presupposes her more fundamental powerlessness" (655). This powerlessness, I contend, rests upon the idea that women can be objectively interpreted via the visual apprehension of others (as is established within the "chastity contest" (Jed 7) in Livy's and Shakespeare's Lucretia narratives). These narratives support a logic whereby exterior, visual readings of women are more authoritative than, and supplant, any power of expression a woman herself may try to wield. This is as applicable to Tarquin when he 'informs' Lucrece that her beauty caused the rape as it is to Romulus, when he overrides the Sabine women's expressions of suffering. Women in these narratives are powerless because they cannot control how they will be visually interpreted and have no authority to assert what they themselves mean. ${ }^{55}$

Moreover, the idea that a woman suppresses or castigates her sexuality by practising chastity suggests that the duel between lust and chastity already exists in her before it is expressed by the rape. The rape, in other words, only externalises - by this logic - the conflict which already characterises her. Lucretia's rape serves as proof that her chastity is

\footnotetext{
${ }^{55}$ For a woman to speak out in protest of the way in which she has been 'read' - to plead, say, against the decisive visual diagnosis others have made of her - was considered inimical to chaste practice, given that in ancient roman culture a woman's speech was affiliated with her sexuality. Detmer-Goebel notes that in Shakespeare's Titus Andronicus, "Lavinia's chaste refusal to say the word 'rape' reminds the audience that even to speak of rape brings a woman shame" (75). Kahn has argued that the editor of the Arden edition of Shakespeare's The Rape of Lucrece, in arguing that " 'Lucrece loses our sympathy exactly in proportion as she gives tongue" " (28), perpetuates the aforementioned logic whereby women's speech is characterised as illicit; the editor effectively likens "Lucrece's speech with a physical organ and makes it sound unseemly (even faintly obscene) for her to use that organ to speak about her violation. That violation, of course, also brought into prominence physical organs about which it was unseemly to speak; to be raped and to speak about it are thus similarly indecorous, alluding to matters about which women in particular ought to be silent" (28).
} 
not an impenetrable fortress of female virtue and male honour: Tarquin claims to have been provoked by precisely those characteristics that were thought to express her chastity, to express her safeguarding of Collatinus' honour. The supposedly stable semiotic distinction between chastity and beauty is confused by the encounter: Lucretia as viewed object is shown to provoke criminal rape as well as, simultaneously, exuding chaste impenetrability. For order to be restored to this diegetic world - in which so much is vested in female chastity and everything it is thought to contain and safeguard - the semiotic boundaries need to be reset. Chastity has to be castigated of its ravishable potential; inappropriate desire has to be stripped of its capacity to penetrate virtue.

In both Livy and Shakespeare's renditions, Lucretia herself is portrayed as understanding herself in terms of how others see her. Imagining herself as a figure upon whom others will look back, she insists upon her death as self-punishment, claiming, "no unchaste woman shall henceforth live and plead my example" (Livy 67). Her own perspective upon herself as viewed from the outside is dramatised in Shakespeare's poem when, looking at a tapestry depicting the Trojan war, she looks at and criticises - rather than sympathising or identifying with - Helen of Troy. Considering the scene she instead cries, “ 'Show me the strumpet that began this stir, / That with my nails her beauty I may tear' " (1471-72). Her hatred for Helen's ostensibly provocative, guilty beauty - and, by analogy, for her own beauty - is demonstrated further when she explains the rape to Collatinus, telling him that Tarquin's “ 'scarlet lust came evidence to swear / That my poor beauty had purloined his eyes; / And when the judge is robbed, the prisoner dies' " (1650-52). In this statement Lucretia imagines her beauty as a punishable thief; a deviant trouble-maker at odds with her chastity. This, I contend, is the logic that informs Lucretia's suicide and allows it, in turn, to set a methodical example for the project of revenge to which Lucretia's kinsmen are impelled.

By killing her body - a vehicle of signs which others interpret - Lucretia castigates the threatening, potentially sexually expressive part of her, the part that has been visually interpreted as provocative and thereby judged guilty of causing rape. Her suicide represents the castigation of what she considers to be her irreparably soiled, guilty, sexually provocative body from her innocent, chaste mind. The suicide can be read as an act committed by one Lucretia against another. It represents the conclusion of the duel between her chastity and her beauty, in which Lucretia ensures that the allure of her beauty will never again override the bounds of her chaste comportment, thus attracting ruin to itself. Thus, though her death is 
portrayed with an aura of tragedy, it also serves as an instance of the way in which "the pathos of Livy's stories displaces the relief at the removal of the threatening element" (Joshel 120). Lucretia's suicide, I contend, doesn't merely provoke the men to overthrow the Roman government. Rather, pitting herself against herself - and stripping herself definitively, thereby, of the element that threatens her chastity - her suicide functions as an enactment of revolution in miniature, as it were, providing the observing kinsmen with a template of what needs to be done to kill off the illicit elements that threaten greater Rome. Thus does Brutus, Jed writes, react to Lucretia's suicide "by promising to castigate Sextus for his lust and to restore chastity to Rome" (15).

That Lucretia's 'solution' to compromised chastity can be read as a model for what Brutus should do next corresponds to the ancient Roman belief that "women in their strictly limited societal roles embodied the state" (A. Parker et al. 564) and that their bodily comportment was microcosmic for what would happen to or was happening to Rome. Women's unchastity signalled social and political calamity; their sacrifice - for example, the killing of a Vestal Virgin or wife whose chastity had been compromised - emblematised the cleansing of threat from the political arena. The idea that Lucrece's rape stands for the violation of more than herself is expressed in Shakespeare's poem when Brutus declares of Lucrece's rape that " 'Rome herself in them [these abominations] doth stand disgracèd' " (1833). Ancient Roman logic also maintained that there were symbolic connections between illicit sexuality and political tyranny; as Jed writes,

passions, inasmuch as they are conceived as inimical to liberty, come to be associated with tyranny. The opposition between liberty and tyranny, then, is drawn in relation to passions; liberty and tyranny are defined according to whether passions are reined in or allowed to reign.

Both Lucretia and Tarquin are, by this logic, identifiable in the wake of the rape as figures for tyranny: ${ }^{56}$ both are now understood to embody illicit, inappropriate passions ${ }^{57}$ of the sort

\footnotetext{
${ }^{56}$ Insofar as tyranny is understood as a concept threatening to and/or inimical to social and political stability (rather than, as it were, the 'iron hand' which maintains order). This is consistent with Jed's use of the term, which she uses, here, as antonym for 'liberty'. Jed defines the latter term in relation to its specific meaning within ancient Roman culture. The ancient Roman concept of "Liberty," Jed argues, "is conceivable only,
} 
which were understood - in the ancient Roman culture to which this diegesis makes reference - to signal social and political calamity. Lucretia inaugurates the process of restoring chastity to Rome (Jed 15) by killing off the part of her that has gone awry; Tarquin's trespass, because it symbolises the tyranny of the greater governing body of which he is part, requires that all those with whom he is politically in league also be executed. The logic behind the significance of Tarquin's actions is driven by the idea, at play in these diegeses, that "forcing a woman to submit sexually was viewed as parallel to dominating one's subjects politically" (Wolfthal 23). Thus the conflict between lust and chastity previously played out by Lucretia against herself - now assumes the form of a battle between the lustful, tyrannical Tarquins and Lucretia's kinsmen, led by Brutus. The latter wield violence as a chastening tool, forcefully removing the Tarquins from power just as Lucretia forcefully removes, as it were, her "threatening element" (Joshel 120) from its seat of command.

according to the terms of Salutati, in a state in which laws exercise a 'sweet control' ('dulce libertatis frenum, quod est iure vivere') (53) over the passions of its subjects. Passions, in contrast, aim at destroying such control, creating in people the desire to overstep the bounds of liberty" (27).

${ }^{57}$ On the one hand, Lucrece is established as the victim of Tarquin's illicit passion. However, both she and the narrator of Shakespeare's poem also make reference, in the wake of the rape, to the idea that she - because she is now unchaste - now embodies and expresses the "illicit sexuality," associated with "tyranny," that Jed describes. Lucrece claims, for example, that an "impious breach of holy wedlock vow" (809) will be visible "character'd in my brow" (807 ); that a "loathsome trespass" will be evident to others in her "looks" (812); speaking as if to her husband, she resolves not to "poison thee with my attaint" (1072). These signs of unchastity are metonymically representative, in the terms of the ancient Roman cultural logic to which Shakespeare's diegesis refers, of tyranny. Under the scheme of this logic, certain women whose chastity was compromised were automatically considered emblematic of both the crime in which they had been involved and the political calamity for which that crime served as omen. Therefore, those women were seen as deserving victims on whose bodies punishment for unchastity - which was thought to signify " 'the pollution of the city' " (Dion. Hal. qtd. in H. Parker 574) - could be appropriately enacted. This was the logic that informed the Romans' treatment of the Vestal Virgins, each of whose "untouched body ... is a metonymy for the untouched city of Rome" (H. Parker 564)."Thus," H. Parker argues, "in times of crisis, she [the Vestal virgin] serves as pharmakos / pharmakon" (564), which is to say, as "scapegoat" or "one chosen ... to atone for a crime or misfortune" $(O E D)$. Shakespeare's Lucrece does liken herself to a Vestal Virgin who has violated her oath (883), but, as H. Parker argues, "the magical and liminal functions of women were not confined to the Vestal Virgins" (592). Rather, "two specific charges of sexual impurity in women - violation of virginity in the Vestals, and adultery in wives - were made responsible for danger to the state" (564). Therefore, H. Parker also concludes that "In times of panic, the society can easily be restored to health by the sacrifice, exile, or punishment of wives" (592). Lucrece, as per the exclamations she makes in the wake of the rape, functions as an omen of Jed's "tyranny" (27) - of "danger to the state" (564). Thus, she vows, "My blood shall wash the slander of mine ill" (1207) 


\section{PART TWO}

Magda 


\section{CHAPTER FOUR}

\section{Communion}

"Communion n. 1. a. The action or fact of sharing or holding something in common with others; mutual participation; the condition of things so held, mutuality, community, union [ . . ]. b. gen. Fellowship; the fact of being associated in one's actions or relations; mutual association, society, converse" (OED)

"There is no act I know of that will liberate me into the world. There is no act I know of that will bring the world into me" (Coetzee, In the Heart 10).

Coetzee's second novel, In the Heart of the Country (1977), is narrated in the firstperson by a woman whose name, we learn at length, is Magda. ${ }^{58}$ Magda's relationship to her surroundings and to the people with whom she lives sharply contrasts with the relationship that Shakespeare and Livy establish between Lucretia and her community. Shakespeare's narrative thematically and structurally establishes that Lucretia and her rape are witnessed: by 'witnessed,' I mean to connote both physical beholdment (something is ocularly perceived) and synthesised hermeneutic apprehension (one interprets a witnessed entity in the same terms $^{59}$ as other witnesses to or actors in that entity). As I argued in part one of this thesis, Collatinus and company's diagnosis of Lucretia as chastest wife (and the associated description of her bodily apparent character provided for readers' elucidation) establishes that her nature is visible on her skin; the prosopopoeical room in which the rape occurs is portrayed as having borne witness to the rape portrayed as objectifiable spectacle; Tarquin, who pre-meditates the rape, and of whose anticipatory thoughts the omniscient narration informs us, witnesses the rape of Lucretia in the sense that he is portrayed as experiencing it as the same kind of event as she does; and finally, structurally, the omniscient narration

\footnotetext{
${ }^{58}$ The narrator's name is not mentioned until page 111 of the 151 page novel.

${ }^{59}$ For example, this sort of synthesis characterises the rape scene in Shakespeare's Rape of Lucrece: as I argued in chapter one (see page 38 of this thesis), Tarquin, Lucretia, and the animated aspects of the surrounding environment involved in the scene's narration (i.e. those elements of the surroundings that are prosopopoeified as onlookers) apprehend the encounter in the same terms (as rape, an assault on Lucretia's famed chastity) as one another.
} 
places the reader in a quasi-spectatorial, seemingly "point-of-viewless" (Rooney 89) perspective, encouraging the illusion (for external readers) that the narrative portrays an objectifiably visible event from a "nonsituated, universal standpoint" (MacKinnon 636).

Lucretia's visibility - the ways in which she is witnessed, that is to say, as described above - contributes to the sense that she is couched in an environment (comprising both people and things) that is optically and hermeneutically attuned to her, in the sense that she is visually beheld with interested attention and that her 'word' (which is to say, her interpretation of events) is concurred with. Others (for example, the judges of what Jed terms a "chastity contest" (7)) are both keen to look at her and - owing perhaps in part to her supremely chaste reputation, confirmed voyeuristically when Collatinus et al. spy her, in the course of that contest, weaving amongst her maids - inclined to accept her word as truth. Thus in Shakespeare's and Livy's narratives a correlation is set up between witnessing and communion, the latter term being defined as the "action or fact of sharing or holding something in common with others; mutual participation; the condition of things so held, mutuality, community, union" and as "Fellowship; the fact of being associated in one's actions or relations" $(O E D)$. In their eagerness to behold her and in their tendency to interpret things in the same way as her ${ }^{60}$ - in their witnessing of her, this is to say - those animate and inanimate components of her environment suggest an engagement in communion with Lucretia. ${ }^{61}$ Alongside this, in her proclivity to offer herself as subject to be witnessed by them - either visually, as is the case during the "chastity contest" (Jed 7), and/or aurally, as when she summons her kinsmen to witness her account of the rape - she suggests the reciprocity of the communion in which she and those around her partake.

\footnotetext{
${ }^{60}$ As I pointed out in part one of this thesis (see note 38, page 35), it has been argued that Lucrece doesn't represent "a female subject" (Kahn 28) so much as function as a mouthpiece via which "the male gaze verbalizes itself" (Kahn 28). She has, that is to say, been interpreted by some critics not as a character, representing an autonomous subjectivity, whose point of view may thus be agreed or disagreed with, but as a vehicle for the expression of a harmonised version of others' points of view: as, say, "a paradigm for all ages of the meaning of female chastity in a patriarchy" (Kahn 28). This analysis of "who or what speaks in the character we call Lucrece" (Jonathan Goldberg paraphrased in Kahn 28) has led Mary Jacobus to ask, for example, " 'Is there a woman in this text?' " (qtd. in Kahn 28). My point herein is not to argue definitively for or against the idea that Lucretia is a "mere trope" (Rody 163) - for or against the idea, that is to say, that Lucrece "speak[s] like a man, for men and the world they control" (Kahn 28) - but to note simply that Lucrece interprets herself in a manner apparently homogenous with her kinsmen's interpretation of her.

${ }^{61}$ This is not to suggest that the rape itself is an act of communion (to the extent that the word communion implies an empathetic condition in which mutually consenting parties are involved). The rape is, rather, an act that Tarquin commits despite a relationship with and to Lucretia that was (previous to the rape) characterised by communion: he both agrees that she is the most chaste of the men's wives (concurring with the other men's, and with Lucretia's, sense of herself and interpretation of her appearance and activity) and apparently enjoys a reciprocal friendship with her: prior to the rape he is, as it were, a part of her inner circle - the "princely guest" to whom she extends "reverend welcome" (141) - a state of communion which he broaches by committing the rape.
} 
These narratives place Lucretia at the centre of a tripartite series of social "actions or relations:" she is the sight whom the men ride from Ardea to look upon, the unsuspecting hostess put upon by Tarquin, and the testifying witness to whose 'confession' a committee of kinsmen is summoned. Thus is a sense of communion established that is sought rather than incidental: Lucretia, and the significant male characters of the story, want to and do focus upon each other. The narratives" "actions or relations" unfold within a web of commonly held beliefs: it is uniformly accepted among the judges of the "chastity contest" (Jed 7), by the omniscient narrator, by Tarquin and by Lucretia herself, for example, that her outward appearance and conduct indexically represent her chastity. ${ }^{62}$ This is to say that Lucretia's understanding of herself is communal, or shared by everyone in the narrative; everyone (i.e. Lucretia, Tarquin, Collatinus, the other characters, and the inanimate objects prosopopoeiafied during the rape scene) agree upon precisely who she is (supremely chaste wife of Collatinus) and what she claims (to have been forced, against her will, to have had sex with Tarquin, to the demise of her chastity). As I argued in part one of this thesis, even Tarquin and Lucretia exist, in relation to the rape, in hermeneutic communion with each other, as though they themselves were able to look upon the rape as objectifiable spectacle and, henceforth, assigned to it precisely the same meaning(s). Tarquin's actions toward Lucretia - which occupy the central position in the triptych of aforementioned social "actions or relations" comprising the narrative - constitute a breach of communion only in that he acts in defiance of his sense that the rape is abhorrent. ${ }^{63} \mathrm{He}$ shares her perception of herself, he shares her sense of the wrongness of the rape, and yet he acts in defiance of these communal understandings and rapes her anyway. His defiance - as breach of communion - sets up part of the raison d'etre of the third social relation: the men whom Lucretia summons as witnesses to her account and suicide are charged with righting the symbolic transgression that the rape represents to their state of collective communion. After she commits suicide, Lucretia's kinsmen commune with each other in order to make sense of her death and to

\footnotetext{
${ }^{62}$ Shakespeare has the company of men dispatch from Ardea in a "pleasant humour," (10) en route to Rome to look at their wives; they see Lucretia, "though it were late in the night, spinning amongst her maids" (13-14) whereas "the other ladies were all found dancing and revelling, or in several disports" (14-15). After having seen these things the men are reported to be in complete hermeneutic agreement regarding the significance of each spectacle; "the noblemen yielded Collatinus the victory," (15-16) Shakespeare writes, "and his wife the fame" (16).

${ }^{63}$ Shakespeare's poem specifies that Tarquin, contemplating the "dangers of his loathsome enterprise" (184) says to himself "die, unhallowed thoughts, before you blot / With your uncleanness that which is divine" (1923 ), indicating his self-awareness of the fact that his rape of Lucrece will constitute the marring of her sacrosanct chastity. In the aftermath of the rape, he is described as a "thievish dog" (736) who "hates himself for his offense" (1. 738), and the narrative indicates that, while Lucrece "bears the load of lust he left behind" (734), he bears "the burden of a guilty mind" (735).
} 
decide how to respond to it, in order to mend the breach of shared values and ideas that it represents for them: with Brutus at the helm of this interpretive / reactive project, they collectively agree to oust the Tarquins as retribution for the rape and as a supposed means to restore communion in Rome. Thus is Lucretia's rape, by virtue of the events it gives inception to, knitted into a collective narrative. Her rape assumes a critical part in the scheme of greater Roman historiography, becoming framed as the event which precipitated the Roman Revolution and, thus, the instigation of a Roman Republic. ${ }^{64}$

In contrast to Shakespeare and Livy's narratives, In the Heart of the Country thematically and structurally explores its narrator-protagonist's sense that nothing / no one looks at her and that nothing / no one is, as it were, 'watching over her.' The narration also suggests its narrator's unreliability, ${ }^{65}$ creating the sense that others (internal or external readers of the diegetic situation) might not (hypothetically) witness ${ }^{66}$ her ostensible rape (or any other described diegetic event) in a manner hermeneutically synchronised with Magda's own descriptions. Coetzee's narrative challenges the assumption that the actors within its diegesis share ocular or hermeneutic perspectives upon events or upon each other, suggesting instead (though never confirming) that these points of view ${ }^{67}$ may be radically different from each other. Just as the Lucretia narratives set up a correlation between witnessing and communion (as argued above), In the Heart of the Country sets up a correlation between lack of witnessing and lack of communion: that Magda's environment (and the people within it) will not or do not look at her is a state of affairs correlative to the suggested absence, in this diegesis, of shared ideas or beliefs and of the inclination of its actors to participate in communal "actions or relations."

In the Heart of the Country conveys a sense of the absence of communion in a number of ways. Firstly, Coetzee's novel suggests that Magda's sense of herself is fragmented, changeable, and potentially incommensurate with others' ideas of her (quite in contrast to Lucretia's comprehension of herself as chaste wife of Collatinus, a characterisation shared - as far as either narrative indicates - by every other actor in Livy and Shakespeare's diegeses). Whereas Shakespeare's Lucretia suggests that she has no control

\footnotetext{
${ }^{64}$ Jed argues that Livy's narrative encourages readers to accept that Lucretia's rape is "a necessary prologue to Brutus' act of liberation" (Jed 11).

${ }^{65}$ In chapter six, I will discuss in more detail the aspects of Magda's narration that seem to, or have been said to, compromise its reliability.

${ }^{66}$ Refer to the definition given on page 66 for this, and all subsequent usage (unless otherwise noted) of the term 'witness' and its conjugations.

${ }^{67}$ I use the term 'points of view' here to connote both its literal and metaphoric meanings, for example 'optical line of sight' and 'hermeneutic perspective.'
} 
over the objectifiably visible manifestation of her character and experience upon her face and body - lamenting that "Yea, the illiterate, that know not how / To cipher what is writ in learnèd books, / Will quote my loathsome trespass in my looks' " (810-12) - Magda is narratorially at the helm of a series of efforts to write herself into certain female stereotypes gleaned from that which is, precisely, "writ in learnèd books." She likens herself throughout her narration, that is to say, to female stereotypes drawn from literature and psychoanalysis; Dodd describes this tendency by noting that Magda "constantly casts and recasts herself according to fictional models .... She casts herself as fin de siècle decadent, gothic villain, madwoman in the attic, and incestuous aristocrat all in the first twenty pages" ("Naming" 158). These descriptions of character come across as writerly exercises: the feminine stereotypes are conveyed as conventional descriptions into which Magda attempts to pen herself, rather than summations of her nature that exude, as it were, from her skin. ${ }^{68}$ Frequently she narrates vignettes in which, exercising a kind of narratorial schizophrenia, she portrays herself as (sole) witness to herself; ${ }^{69}$ in contrast, thus, to the way in which the visual apprehension and deductive summations of Shakespeare's characters serve to authorise Lucrece's characterisation (it is a phenomenon witnessed by many), Magda's characterisation seems inconclusive - or, remains unconfirmed - by virtue of the novel's omission of any other character's or narrator's account of what she looks like and/or who she is.

\footnotetext{
${ }^{68}$ In a manner, that is to say, akin to the way - as I argued in part one of this thesis - that Lucrece's character is described in Shakespeare's poem as being objectifiably visible on her face. Hence we read that on her face "Beauty and Virtue strivèd" (52).

${ }^{69}$ For example, when Magda attempts to commit (or simply play-acts) suicide by drowning, she is the only apparent diegetic witness to herself, though she imaginatively attributes ocular agency to her shoes - musing that, like "abandoned twins, my shoes watch from the bank" (14) - and guesses that the heavens may be surveying her, noting "I cast a long calm look of farewell at the sky and the stars, which probably cast a long calm vacant look back" (14). She describes the way her "underwear balloons in the water" and her "head breaks gasping and retching into the night air" - although she herself were watching herself from the riverbank - but ultimately concludes that she is accompanied only by the absence of others: "Perhaps I beat the water now in one spot only," she notes, "making a last bargain, giving up a breath for the sake of a single word, half water, half plea, to the absent, to all the absent, who congregate now in the sky in a whirlwind of absence, removed, sightless" (14-15). There are a number of other scenes in which Magda describes her reflection, as she stands alone in front of a mirror: "I roll my eyeballs," she notes, "I pucker my lips, I stretch my ears, but the face in the mirror is my face and will go on being mine even if I hold it in the fire till it drips" (17). Later in the novel she begins a passage with the phrase "The mirror" (23), stating therein that "I sometimes leave the light burning and recline abed sustained on my elbow and smile at the image that reclines abed facing me sustained on an elbow, and sometimes even talk to it, or her" (23). Sometimes she imagines the woman in the mirror as an autonomous entity who watches her back, referring to her reflection as "The woman in the nightcap watching me from the mirror, the woman who in a certain sense is me" (25). The critical, sometimes clinical, sometimes repulsed tone with which Magda - assuming a narratorial distance - describes herself is perhaps best encapsulated when she likens herself to an entomological specimen, "a thin black beetle with dummy wings who lays no eggs and blinks in the sun, a real puzzle to entomology" (20).
} 
Secondly, in Coetzee's novel the expectations that Magda brings to her natural surroundings - that they be invested with some degree of spiritual or animistic presence - are self-reflexively critiqued, by Magda, to be just that; her expectations remain located within her as a set of desires that she imposes upon her surroundings. ${ }^{70}$ This stands in contrast to Shakespeare's narrative, wherein, as I have noted, the surroundings themselves are attributed with autonomous agency: whereas Lucretia's environment colludes in the confirmation of her characterisation, the "lonely farmhouse and stone desert" (13) of Magda's diegesis turns only (as far as the novel permits us to conclusively gather) a blind eye toward her.

Thirdly, Coetzee's narrative omits any description of Hendrik's thoughts - other than that contained within Magda's speculations - and any focalisation of events via Hendrik's perspective. ${ }^{71}$ Unlike Shakespeare's Tarquin, thus, Hendrik cannot be counted as witness to Magda as she describes herself, nor to the rape ${ }^{72}$ as Magda describes it, in that we cannot know if and/or how he (hypothetically, diegetically) experiences her, or if and/or how he experiences what she describes.

All of this - the ways, that is to say, in which In the Heart of the Country conveys Magda as a unwitnessed entity - comprises a thematic and structural basis for the novel's exploration of Magda's longing for (and persistent failure to achieve) communion with those who (and with that which) surrounds her. The characterisation of Magda as someone who longs to be empathetically gazed upon ${ }^{73}$ and understood by others - and to, in turn, be able to and permitted to reciprocate this empathy - has an impact upon the way that her rape functions, or is read, within the scheme of the narrative; Magda herself, and critics who have interpreted her narration, examine the rape's potential to function as a way for her to achieve

\footnotetext{
${ }^{70}$ For example, Magda self-reflexively notes that her relationship to the surrounding environment is characterised by "the vain urge of my consciousness to inhabit it" (53).

${ }^{71}$ Nor does Coetzee's narrative portray the thoughts or optical perspective of any other character besides Magda; I highlight Hendrik here simply because he is the other actor involved in the ostensible rape with whose analysis I am primarily concerned.

${ }_{73}^{72}$ Or, ostensibly, rapes.

${ }^{73}$ On different occasions when they are in bed, Magda stares at Hendrik - ostensibly hoping for her gaze to be returned - and asks him if they might light a candle so as to better see each other. In the first instance, when she turns toward and looks "full at him" (118), he "rubs his face in his cupped hands" and leaves, rather than looking back at her (118-19). Later, Magda notes that she "would like a chance to look at him" and asks him " 'Hendrik, why won't you let me light a candle? Just once?' " adding “' 'I just want to see how you look', " a proposition which Hendrik answers, in Magda's account, with an emphatic “ 'No, don't!' " (120-21). In a subsequent speech she verbally implores Hendrik to "Look at me!," drawing a rhetorical parallel between his refusal to look at her (in the literal sense) and what Magda perceives as his failure to "see' who she really is. " 'You are so bitter that you are completely blinded,'" she tells him, asking " 'Can't you see that you and Anna are the only people in the world I am attached to?'” (128)
} 
the communion for which she longs. ${ }^{74}$ In other words, even as the term 'rape' conventionally connotes the unwanted, In the Heart of the Country has prompted the question of whether Magda's rape - an event which ostensibly brings her closer, at least in body, to someone with whom she desires communion - affords her something wanted (and whether, and at what cost, we are inclined to read it that way).

As I have mentioned, Magda's surroundings are animated, or assume agency, only in her musings; Coetzee's narrative contains no suggestion that the walls of the house, or the plains of the veld, actually watch, speak, or react to the book's narrator. "When Magda looks out her window she sees a natural world that has nothing to do with her and cannot meet her desires," Rody has noted (172). However, In the Heart of the Country conveys Magda's expectations of her surroundings, expectations which are inflected both by cynicism and desire: if she does not reasonably expect angels to descend from on high, nor rocks to speak to her, then her monologues also indicate a persistent longing for the house and veld to somehow commune with her. Immediately after the series of passages in which she describes what may be interpreted as her initial rape(s) by Hendrik, Magda muses that these things have happened to her in unwitnessed isolation, an isolation imagined here as the natural environment's indifference to her and as the apparent absence of intervening celestial forces. "The last of the afternoon is wheeling past," she narrates,

while I lie beside this man seeping tears and blood. If I were to get up now and walk, for I can still walk, I can still talk, if I were to walk out on the stoep, my hair tangled, my buttocks sagging, my thighs smeared in filth, if I were to come out into the light, I, the black flower that grows in the corner, dazzled, dizzy, I am sure that in spite of it all it would be an afternoon like any other, the cicadas would not pause in their grating, the heatwaves would still thrill on the horizon, the sun would still lie ponderous and indifferent on my skin. I have been through everything now and no angel has descended with flaming sword to forbid it. There are, it seems, no angels in this part of the sky, no God in this part of the world. (117-18)

\footnotetext{
${ }^{74}$ For example, Rody has argued that Magda "tries pathetically to interpret Hendrik's act of hatred as an act of love" (175). Gallagher posits that Magda longs to believe that the rape represents "the path to intimacy for which she has been searching" (102).
} 
But Magda's commentary upon the failure of celestial forces to prohibit what happens to her - indeed, on the world's ostensible tendency not to respond to or be disrupted by this event at all - does not represent the limit of her reaction to others' apparent indifference toward her; her reactions extend past lamentation, to projection. ${ }^{75}$ It is at this point that her desire for communion assumes a form that is potentially antithetical to the project of communing with others: by impersonating others' points of view - i.e. imagining via the forum of her narration that she may authoritatively see what they see, relate what they think, and reveal the motivations which underlie their actions - Magda authors that which is unknown to her. This 'authoring,' while it presumably answers to her desire (to exist in empathetic communion with others), simultaneously occludes the desired (she shuts out the possibility of others' stories by claiming authorship of them for herself).

In one passage she imaginatively assigns behaviour to certain aspects of her bedroom, defining for herself a role central to their existence. Here she imagines that the roses on the wallpaper define themselves in opposition to her and feed off the taunt of their inaccessibility to her; she explains her environment's indifference to her, that is to say, in a manner that centrally involves her (albeit via exclusion) in its existence. Entering her room, she narrates that

I close the door, sit down, and confront with unweeping eyes the patch of wallpaper above the desk [. . .] the consolation that keeps me from closing my eyes, folding my arms, and rocking myself forever into vacancy, is the knowledge that from me and from me only do these flowers draw the energy that enables them to commune with themselves, with each other, in their ecstasy of pure being, just as the stones and bushes of the veld hum with life, with such happiness that happiness is not the word, because I am here to set them vibrating with their own variety of material awareness that I am forever not they, and they not I, that I can never be the rapture of pure self that they are but am alas forever set off from them by the babble of words within

\footnotetext{
${ }^{75}$ Defined as the "process of causing thoughts, ideas, or emotions to exist, or appear to exist, in the external world; an instance of this, a mental image visualized or regarded as reality" $(O E D)$.
} 
me that fabricate and refabricate me as something else, something else. $(52-3)^{76}$

Coetzee's portrayal of Magda's interpretation of the wallpaper - an imaginative act of projection in which she centres herself as the ego in opposition to which the roses' identity is formed and thrives - suggests her own authoring of, rather than her eliciting of, a response from (in this case) the insentient world. Though the above passage concludes with the suggestion of her own awareness that her efforts are egocentric - terming her failure to establish communion with her environment "the vain urge of my consciousness to inhabit it" (53) - she circularly asserts that the environment is "exalted" by her failure and claims to perceive its (communal) attitude by claiming that "the farm, the desert, the whole world as far as the horizon is in an ecstasy of communion with itself' (53). Thus, though Magda seems self-reflexively able to identify her efforts as egocentric projection, this awareness is persistently overthrown by the recurrence of her longing for communion with her surroundings and the people who surround her, a longing that - I argue - prompts her continued engagement in imaginative projection. She seems unable to respond to her longing in a way that does not involve the putting, as it were, of words into others' mouths.

Other instances of Magda's forays into omniscience - passages of narration in which she quasi-knowingly describes that which, elsewhere, she identifies as unknown to her - fill Coetzee's novel. On the first page she admits to describing what she has not witnessed: after detailing the manner in which her father arrives home with his new bride, she adds, "more detail I cannot give unless I begin to embroider, for I was not watching" (1). She repeatedly

\footnotetext{
${ }^{76}$ This passage also comprises an example of the kind of literary-influenced characterisation in which I claim Magda engages; the scene in which Magda comments upon her bedroom's wallpaper can be read as a reference to Charlotte Perkins Gilman's story "The Yellow Wallpaper," in which the lead female protagonist comments upon the "sprawling flamboyant patterns" (3) of the wallpaper in a room at an ancestral hall (1) where she and her husband are spending the summer. She, too, imagines that the paper (or creatures 'behind it') are animate, claiming "it looks to me as if it KNEW what a vicious influence it had!," (5) and that "I never saw so much expression in an inanimate thing before" (5). Eventually she imagines a shape "like a woman stooping down and creeping about behind that [wallpaper] pattern" (8), and fathoms that "that woman gets out in the daytime .... It is the same woman, I know, for she is always creeping, and most women do not creep by daylight" (12); her description of the woman is echoed in In the Heart of the Country when Magda, concluding her meditation on the wallpaper roses, wonders what would happen were she to "creep away till better days come" (54). Gilman's narrator, locking herself in the room (14), begins, herself, to "creep around as I please" (14); when her husband breaks down the door and faints at the sight of her she notes that his body lay "right across my path by the wall, so that I had to creep over him every time!" (15). Gilman's story references Victorian ideas about the female hysteric, a psychoanalytic construct explored in Freud's Studies on Hysteria which, Briganti argues, constitutes "an important subtext of Magda's narrative" (35)
} 
offers this sort of confessional addendum to her passages of description, noting in another part of the novel that

The question to ask is not, How do I, a lonely spinster, come to know such things? It is not for nothing that I spend evenings humped over the dictionary. Words are words. I have never pretended to embrace that night's experience. (29)

She persists in describing that which she apparently wants to (but does not) know or witness. Sometimes, she merely imagines that her own feelings are shared by everyone on the farm, insisting for example that "what I feel blowing in on the thin dawn wind is not felt by me alone. All of us feel it, and all of us have grown sombre" (27). Such passages suggest a role for imagined omniscience that is not far removed from habitual rhetorical convention: in order to emphasise the gravity of her own feelings, Magda describes her anxiety as pervasive, felt by others, or tangible in the air. But if Coetzee's narrative sometimes suggests that imagined omniscience is merely an offhand convention of English language prose style, then it also, elsewhere, suggests that our capacity to write other people's stories - to describe their thoughts, rationalise their actions, and/or provide their history - has an invasive, violatory, supplanting potential. As such, the novel draws critical attention to the notion of communion, suggesting the potential impossibility of a genuinely empathetic state of communion in which ideas or beliefs are held in common.

Theorist Emmanuel Levinas might be said to assume a critical stance toward the ethical implications of the idea of communion, in which "the condition of things so held, mutuality, community, union" is posited. He claims, rather, that "To be ethical [. . .] is to be utterly unable to know the other; human ethics is beyond my limited and subjective knowledge base" (Levinas paraphrased in Burton, 10-11). He affords visual apprehension a great deal of importance, but does not equate reciprocal gazing with communion. Rather, he argues that the "face-to-face relation" (Moran 350) involves encountering another person's irreducible otherness. "For Levinas," Joel Burton argues,

the presence of self and other is felt by a combination of the five senses, the most predominant of which is the sense of sight. $I$ see and thus encounter the other; the other sees and thus encounters me. (11-12) 
In the light of Levinas' understanding, the idea of communion - as portrayed, for example, in Shakespeare and Livy - suggests a failure to sufficiently acknowledge potentially incommensurate points of view rather than the existence of a truly synthesised sense of vision and thought. Shakespeare's and Livy's portrayals of communion correspond to the conventions of the socio-historical cultures which their diegeses reference. However, when Magda adopts similar notions of communion in relation to her own spatio-temporal surroundings - assuming, for example, that shared ideas and beliefs are held by the servants ${ }^{77}$ with whom she shares the farm, and by her surroundings ${ }^{78}$ - her pursuit of these notions only seems to increase her sense of isolation from those around her, and to suggest that she is merely speculating upon, rather than communing with, those to whom she attributes synthesis of thought and feeling. In the Heart of the Country expresses the idea that, where communion is posited, shared perspective is assumed or imposed - by an agent claiming mastery of that which is described - rather than naturally or neutrally occurrent.

Magda's meditations on the "psychology of servants" sees her imagining a group of people as a cohesive race to whose innermost feelings she has privileged access; they feel, she narrates,

all their feelings not successively in waves of contraries but simultaneously as a hotchpotch of rage, regret, resentment, and glee, they experience a giddiness that makes them long to be asleep. They want to be in the big house but they also want to stay at home malingering, dozing on a bench in the shade. Cups fall through their fingers and shatter on the floor. For no good reason they scold their children. They have bad dreams. (7-8)

Voiced by an omniscient narrator, the reliability of these comments might seem plausible; one may take issue with the totalising, reductive effect of the claims, but the conventions of omniscient narratorial insight encourage readers to go along with the conceit that such a narrator has unmitigated, reliable access to the feelings and longings of all characters in a diegesis. Voiced by Magda, it seems improbable (as it would coming from any intradiegetic,

\footnotetext{
${ }_{77}^{71}$ As when she speculatively summates the "psychology of servants" (8).

${ }^{78}$ As when she posits that "The farm, the desert, the whole world as far as the horizon is in an ecstasy of communion with itself" (53).
} 
non-omniscient narrator) that these observations constitute more than her own generalising assumptions. The reliability of her comments here is further undermined by statements that she makes elsewhere in the narrative, such as her claim to "know nothing of Hendrik" (27).

Magda's comments on the psychology of servants indicate a desire to reduce the feelings and longings of those to whom she refers into a simple, generalisable whole; her tone, and the content of her analysis, is patronising and paternalistic. In other passages, her conception of the lives of others involves, as it does in the wallpaper scene, the centring of herself as a force in relation to which others' relationships and identities are formed. For example, she conceives of a role for herself, as fodder for erotic stimulus, in Hendrik and Anna's marriage. Putting words into Hendrik's mouth by means of indirect free discourse and, incidentally, inverting the situation so that, in this passage, Hendrik seems to speculate upon her (Magda's) inner workings - she imagines that Hendrik tells Anna

what I need. He tells her that I need a man, that I need to be covered, to be turned into a woman [...]. Someone should make a woman of me, he tells her, someone should make a hole in me to let the old juices run out. Should I be the one to do it, he asks her, to climb through the window one night and lie with her and make a woman of her and slip away before dawn? Do you think she would let me? Would she pretend it was a dream and let it happen, or would it be necessary to force her? Would I be able to force myself in between those scraggy knees? Would she lose her head and scream? Would I have to hold her mouth shut? Would she not be as tight and dry and unrelenting to the last as leather? Would I force my way into that dusty hole only to be crushed to a jelly in a vice of bone? Or is it possible that after all she would be soft, as a woman is soft, as you are soft, here? And Anna pants in the dark, cleaving to her man. (94)

Her envisioning of an erotic encounter between Anna and Hendrik suggests an tendency, evidenced elsewhere in the novel, to characterise Anna in particular as a more sexual, and thus - the correlation is Magda's - more simple-minded creature: for example, in a statement notable for its connotations of metaphysical rape, Magda confesses that she "would like to 
climb into Klein-Anna's body," (118) an activity via which, the narrator imagines, she would experience Anna's (assumed) inclination to "wait mindlessly for whatever enters ... the song of birds, the smell of dung, the parts of a man" (118).

Thus, I argue, if Magda's forays into imagined omniscience stem in part from a genuine desire for communion with Anna and Hendrik, they also indicate another desire: that by which Magda seeks to master the subjects of whom she speaks. By mastery, I mean to connote both the totalising effect of Magda's claims to thorough knowledge of these people's inner workings, and - in contextual relation to the apartheid-era South Africa that Coetzee's diegesis references - her effort to (re)assert a particular characterisation for Anna and Hendrik (Servant) in relation to a particular subject role that she concomitantly re-asserts for herself (Master). The relationship that Magda longs to enter into with Anna and Hendrik is sometimes lent vague shape in the narration as a relationship that would transcend the societal dimensions of apartheid. This might involve (for example) equality of status, cooperative work, communal eating, and the amicable perusing of shared memories amongst all of the people (formerly defined as Masters and Servants) in a household. ${ }^{79}$ In one instance Magda conceives of this idyllic relationship as "a language lovers speak," conceding that she "cannot imagine how it goes" (106). However, in imagining what could bring about the instigation of a peaceful, orderly relationship between herself, Anna and Hendrik, Magda also persistently expresses nostalgia for apartheid-type relations of segregation and subjugation. She attests for example that

I am a conserver rather than a destroyer, perhaps my rage at my

father is simply rage at the violations of the old language, the correct language, that take place when he exchanges kisses and the pronouns of intimacy with a girl who yesterday scrubbed the floors and today ought to be cleaning the windows. (47)

\footnotetext{
${ }^{79}$ In one series of passages, Magda describes a series of events that may be interpreted either as a representation of or as a fantasy of a diegetic period of time during which Magda, Anna, and Hendrik collaborate in a seemingly amicable relationship, ostensibly involving equality of status and cooperation in performing tasks at hand. During this series of passages, Magda describes an instance of reciprocated vision - a gaze met and returned - that momentarily connotes the idea of communion espoused in The Rape of Lucrece: "Hendrik's eyes meet mine," she narrates. "We see the same purpose. I smile, and he smiles" (88). (This is not the only incident in which Magda associates a shared gaze with intimacy; of her father's ostensible liaison with Hendrik's wife, she narrates that "Through wisps of steam, their eyes meet" (57)). Magda goes on to describe how she and Hendrik work together on the house, noting that "our honest sweat flows together in the dark warmth" (89); how Anna brings them "mugs of coffee and slices of bread and jam" (89), and how they rifle through a chest of old photographs together, noting that Hendrik "picks me out unerringly among the other children" (90).
} 
Perhaps, as Rody argues, "Magda does make it possible for Coetzee to suggest, as do Forster and Rhys, that a white person can become imprisoned by privilege and wish for relationships of equality across the hierarchical divisions of her world" (173). However, I would add, Coetzee's novel also explores the potential of this 'wish' to manifest itself in ways that threaten to reinstate, rather than to transcend, the ethos of apartheid society.

Rody argues that, in In the Heart of the Country, "the psychosexual desire of whites for blacks is double-edged, at once exploitative and genuine" (173). On the one hand, for example, I interpret Magda's forays into omniscience as a response (albeit a flawed and ineffective response) to her intense, unreciprocated longing to know about the people around her - to be let in, as it were, on their secrets, and to let them into hers - and I think that this longing involves a genuine desire to establish reciprocal relationships, empathetic communion, with the people around her. Of the scene in which Magda describes (potentially imaginary) siblings, (51-2) Gallagher writes that "Magda's imaginary families, like Huckleberry Finn's similar narrative clans, reveal her frustrated desire for human community" (97). However, as is the case with Rody's argument, I feel that this statement needs qualification. In practice - in language - in response to this "desire for human community" - Magda does not, as Rody argues, place Hendrik and Anna at the centre of her life so much as conceive a role for herself at the centre of their lives. In doing so, she does in fact continue to marginalise Hendrik and Anna. The dual welcoming / marginalising effect of her ostensibly well-intentioned efforts toward Hendrik and Anna is expressed figuratively in the novel when she commands the couple to move into the main house, suggesting that they sleep not in a bedroom but on a makeshift bed on the kitchen floor. In formal terms, Magda's invitation $^{80}$ - phrased using a compound of commands ("you must," "I want you to") and vaguely patronising imperatives ("come along, Anna") - fails to depart from the conventional form of command made from master to servant; its bidding (that the servants bed upon the kitchen floor) represents a lateral alteration to the living arrangements (the servants are shifted from one inferior position to another) rather than the kind of hypothetical change that might symbolise their status as equals in the house. ${ }^{81}$

\footnotetext{
80 " 'I can't sleep alone tonight,'” "Magda tells Hendrik and Anna, adding " ' ( $t$ )he two of you must come and sleep in the house tonight" " (95). In response to their hesitation and initial declination, she notes that "I grow stronger as he grows weaker," reiterating to that " 'I want you to sleep here, just for the one night. Otherwise I am all alone in the house. We can make up a bed on a mat in the kitchen, it will be quite comfortable. Come along Anna, come and help" " (95).

${ }^{81}$ Later in the novel (119), Magda again invites / commands the servants to move into the house, extending at this point a more generous offer of accommodation ("there is no reason why you shouldn't sleep in the guestroom," she concedes). The language in which her second offer is extended, however, again graduates (or
} 
I have suggested that Magda's longing for communion fuels her continued tendency to imagine that she has omniscient insight into the lives of others, despite a self-reflexive awareness that her 'insights' constitute the projection of her own thoughts and desires, upon others; periodically, she also indicates that she is dogged by a sense of despair at the lack of prohibition her authorial ability comes up against. Her ability to describe what she does not know or has not experienced does seem to function for writerly Magda as a source of creative relief, and to correspond to her desire to be cast as an integral part of a larger narrative plan: this is evident in passages where she describes herself as obligated to author a meaningful life-narrative for herself, arguing that

The woman in the nightcap watching me from the mirror, the woman who in a certain sense is me, will dwindle and expire here in the heart of the country unless she has at least a thin porridge of event to live on .... It is up to me (25).

Thus she purports to assume, in relation to herself, the role taken up in The Rape of Lucrece by the omniscient narrator and (in conjunction) Brutus: to incorporate the story of her life into a greater narrative, as integral component, thereby deciphering the meaning, in relation to a narrative context larger than herself, of what happens or has happened to her. However, the extent to which she finds herself at liberty to impose narrative explanation upon the world around her - to tell others' stories without authorisation or objection from others or from, as it were, on high - also causes her to panic and to intermittently express a wish for her own powers of narration to be curtailed. In this respect she resembles Joan Gillmer's description of one of the protagonists of Coetzee's first novel, Dusklands, Jacobus Coetzee, who, Gillmer argues,

finds himself despairing that there is no longer any resistance to his omnipotence. He is totally enclosed in an ego-

reverts, as it were) from an appeal - albeit punctuated as a statement, not as a question - indicating the suggestion's status as optional invitation ("will you and Anna come and sleep in the house from now on") to a command, indicating that they must do as she bids ("(b)ring along everything you need, then you won't have to run back and forth"). Also, she again frames the question around her own needs, stating that she wants them to move in because "I get too nervous when I am alone." Clearly the second offer does not, then, represent a significant departure from the terms upon which the first was made (Hendrik and Anna are not being offered a choice so much as an order, nor are they being welcomed as equals so much as commanded to perform certain acts in order to gratify the needs of their mistress). 
centric vacuum, estranged from his own humanity, listening to his theoretical speculations, afraid there may be nothing 'outside.' (110)

Thus Magda concludes her meditation on the roses by asking herself whether she herself is the so-called "beast" that haunts her: described as something that "is not enchanted by my prattle" (53) and "stalks me through the afternoon" (53) - some kind of looming, unappeasable sense of dread, then - she first wonders whom or what the beast might, in more attributable terms, comprise. Mulling over the candidates - her father, Hendrik, Anna - she assigns to these potential 'beasts' attitudes similar to those with which she credited the wallpaper roses: smug exaltation based upon her exclusion from their circles. "I talk and talk to keep my spirits up," she narrates, "while they [her father, Hendrik, and Anna] circle me, smiling, powerful" (53-4). Ultimately though, she wonders if her tendency to make up stories for things and people is itself the cause of her dread, asking "Is it possible that I am a prisoner not of the lonely farmhouse and the stone desert but of my stony monologue?" (13) The assignment of her own summations of character and motivation to others - whether fostered by a desire for idyllic communion and/or driven by the desire to keep the servants, as it were, in their place - seems to succeed only in making her more acutely aware of the unilateralism of her deductions. Coetzee has argued himself that In the Heart of the Country at once conveys the urgency and futility of Magda's efforts: "At a certain point"” in the novel, he has argued,

she tries to drop the master/slave relationship in favour of a relationship of equality which I think is entirely sincerely intended on her part. But it fails, and it fails because a mere effort of the will is not enough to overcome centuries of cultural and spiritual deformation (Interview with Folke Rhedin 7).

It becomes evident that Magda's sense of what constitutes sexual intimacy involves, and is perhaps inextricable from, notions of subjection and humiliation fundamental to the " 'centuries of cultural and spiritual deformation,'" (7) which form the legacy, Coetzee argues, of Afrikaner culture. Gallagher posits that a "key element" of Afrikaner culture "is its twisted 
emphasis on submission to authority in the form of humiliation" (91), an argument supported by Coetzee's assertion that

'the humiliation of the weak by the strong has been a characteristic practice of the Afrikaner within his own culture, a practice underpinned by a perhaps perverted reading of Scripture which gives inordinate emphasis to authority and its converse, abasement.'(qtd. in

Gallagher 91-2)

As a protagonist written into a diegesis that evokes this culture - summarily termed "South African baasskap [literally, boss-ship]" by Coetzee (qtd. in Gallagher 92) - Magda's concept of human relationships (even those imagined by her as bearing the potential to become truly reciprocal, to graduate into something resembling the "ecstasy of communion" (53) she perceives in her surroundings) seems to inextricably involve elements of subjection. She oscillates between attempts to submit willingly to Hendrik's unsolicited treatment of herhoping in time that this attitude of submission to "humiliation" (122) will alter the parameters of their relationship "for the better" (120) - and attempts to get Anna to submit to insistent physical and conversational entreaties. Claiming for herself the role of " "the unloved,",82 Magda imagines and attempts the extension of her love to others (for example, by attempting to engage in conversational and physical intimacy with others) in terms that involve her own subjection to violation and humiliation, or the inverse subjection of those whom she wishes to 'love;' it's a doubly focused enterprise waged perhaps in the spirit of " 'the castrating urge behind South African baaskaap ... that the castrated, the unloved, usually takes his place at the forefront of the castrators" " (Coetzee qtd. in Gallagher 92).

I mentioned above Magda's indication that she "would like to climb into KleinAnna's body" (118), an imaginary act that might not suggest abasement - of "submission to authority in the form of humiliation" (Gallagher 91) - were Magda to imagine it as an as-yet undefined encounter with the mysterious, unknown territories of someone else's interiority.

\footnotetext{
${ }^{82}$ Magda, who terms herself a "lonely spinster," (29) thematises her 'unlovedness' in various ways throughout the novel: for example, she notes her father's indifference to her, stating that "My father pays no attention to my absence. To my father I have been absent all my life" (2); she speculates upon hypothetical suitors' repulsion to the sight of her, asking "who would not turn to ice at the spectacle of my bony frame on the wedding-couch" (11); of her body she asks, "Unloved, it has been unloving. But has it been hated?" (127)
} 
However, the stance of omniscient insight into Anna's selfhood (the experience of inhabiting Anna's body and mind) that Magda assumes - claiming that Anna experiences the world, including the sexual advances of others, "mindlessly" (118) - connotes a belittlement of Anna, a speculative and reductive act of characterisation by means of which the other woman's body becomes a tabula rasa onto which Magda (authorially, masterfully) etches her own assumptions. Her earlier contemplation of 'Klein-Anna' (and the latter's ostensible sexual involvement with Magda's father) also indicates that Magda comprehends sexual intimacy as a situation of subjection to which Anna either submits "mindlessly" (118) or in which she somehow masochistically revels. Omitting from her consideration the possibility that the sexual relationship in question (or, indeed, any sexual relationship) might involve reciprocal desire or love, a situation in which the subjection of neither person involved is implied, Magda wonders of Anna "Does she merely part her thighs, stolid, dull-nerved, because he is the master, or are there refinements of pleasure in subjection" (57). When Magda herself actually approaches Anna while the latter lies alone in her bed, she (Magda) reacts to Anna's non-responsiveness to conversational entreaties - her non-responsiveness, that is to say, in terms other than sobbing ${ }^{83}$ - with relief, rather than interpreting these signs as an indication that her (Magda's) company is unwanted. Rather than seeking or taking leave because of the lack of reciprocated communication, Magda interprets Anna's nonresponsiveness as carte blanche for her to say or do to Anna what she will: "This is not going to be a dialogue, thank God," Magda notes, reasoning therefore that "I can stretch my wings and fly where I will” (110). Thus she climbs uninvited into bed beside Anna (110), cradling "her head on my arm" (110), entreating Anna to call her by her first name (111), and kissing her forehead despite the fact that Anna apparently "struggles, then stiffens and endures me" (112). Despite her apparent comprehension of Anna's unwillingness to enter into conversational or physical intimacy with Magda, Magda interprets her own actions not as a means by which she subjects unwilling Anna to her own desires but as a means by which she "is doing my best in this unfamiliar world of touch" (112). Thus do her efforts at attempting to instigate some sort of intimate communion with Anna involve Magda taking, as it were, her " 'place at the forefront of the castrators'(28)" (Coetzee qtd. in Gallagher 92): Magda cuts off Anna's voice, ignores Anna's non-consent, subjects Anna to apparently unwanted treatment.

\footnotetext{
${ }^{83}$ Magda narrates that, as she sits by Anna's bedside, Anna "snuffles miserably" and "sobs drearily" (110).
} 
Taking into consideration the extent to which Magda's concept of intimacy involves degrees of mastery and subjection, one may return, with greater insight, to the question of whether Magda's ostensible rape by Hendrik provides her, paradoxically, with something (i.e. some form of communion with Hendrik and Anna) that she wants. Considered in the light of the expectations outlined above - her seeming expectation, for example, that involvement in a relationship of communion with another person will involve either submission to, or the forcing of someone else to submit to, humiliation - rape becomes a horrible figure for, rather than an opportunity to transcend, her extant idea of what constitutes intimacy. The rape does not satisfy Magda's desire for some form of ill-defined, equalfooted, reciprocal communion that would transcend the bonds of master-slave relations - that vague state which, I have argued, she refers to as a inconceivable "language lovers speak" (106) - but rather epitomises the terms of mastery and subjection which give shape to her extant sense of what constitutes intimacy. I call this a 'horrible figure' because it functions to indicate the extent to which Magda conceives of love as a sort of rape: as a process, that is to say, by which one is physically mastered, by which one's protests are castrated, by which one is made subject to someone else's will. The rape confirms, for Magda, everything that she already suspects intimacy to consist of, while affording her no transcendence of that suspicion.

Thwarting conventional expectations of what can be known about a literary character - and thus allowing for the potential imposition of readers" own "speculative bias[es]" (21) In the Heart of the Country poses a chance for its critics to ask what totalising or projective tendencies may be at work in our own reading practices, tendencies that perhaps extend from the desire to 'commune' with a literary protagonist. Coetzee's novel orients its external readers toward Magda in a manner which mimics her orientation toward other intradiegetic characters: disallowed omniscient, authoritative, "point-of-viewless" (Rooney 89) perspective upon diegetic events (in much the same way that Magda is unable to authoritatively, omnisciently 'read' those, and that, which surround her), readers are left only to admit a certain ignorance of, or to guess at (in consultation with our own "extra-textual predilection[s]" (Dodd, "Naming" 157)) who she is, what she thinks, and what 'really' happens in the diegesis. Just as Magda's desire for 'communion' with Hendrik and Anna is shown, I have argued, to include a will toward mastery, my ostensible desire as reader to 'commune' with Magda - to get in, as it were, on the secret of who she really is and what she really does - may involve a desire to 'over-write' her narration, to impose on it my own 
narrative of her, thus mastering her story for myself, in the name of communing with the ‘true story' of Coetzee's novel. 


\section{CHAPTER FIVE}

\section{Memory}

In In the Heart of the Country, Magda's initial descriptions of her sexual encounters with Hendrik begin on page 113 and fill eight distinct, numbered passages, six of which I am concerned with here. The first three concern an encounter in the kitchen. In passage 208, the action has shifted to the bedroom, but the narrative provides no explicit description of how or why diegetic events have shifted venue. The final three passages narrate the immediate aftermath of the encounter.

Certain inconsistencies between these passages have served as touchstones for critics' assessments of whether Magda's descriptions of these encounters with Hendrik are the stuff of diegetic reality or fantasy. These assessments fit into a greater critical discussion concerning the narrator's "disquieting unreliability" (Attridge Modernist Form 23) in In the Heart of the Country. Critics' doubts are informed by phrasal and factual differences between the statements (phrasing varies, initial assertions are undermined by subsequent claims); by the frequent use of adverbial modifiers such as "perhaps," indicating uncertainty or invention; ${ }^{84}$ and by a lack of explanatory transition between 'scenes' (something happens in the kitchen and in the bedroom, but no progression from room to room, nor indication of elapsed time between the two described scenes, is described), ${ }^{85}$ a facet of the narration that undermines the conventions of narrative realism. ${ }^{86}$ These elements of the narrative, some

\footnotetext{
${ }^{84}$ The first section of the book provides much-cited examples of the modifying statements to be found throughout the remainder of the novel. Describing the homecoming of her father and his new wife (an event which, 17 pages later, she claims did not happen), Magda first claims that they "came clip-clop across the flats in a dog-cart drawn by a horse with an ostrich-plume" (1) but then adds that "perhaps they were drawn by two plumed donkeys, that is also possible" (1). Next she claims that in fact she was not present at the scene - "More detail I cannot give unless I begin to embroider, for I was not watching" (1) - but her descriptions of what she in fact was doing during this time are equally ambivalent. "I was in my room reading a book" (1) she claims, followed by the observation that "or, more likely, [I was] supine with a damp towel over my eyes fighting a migraine" (1).

${ }^{85}$ Nor is it made clear whether any time elapses between these encounters.

${ }^{86}$ Conventionally, realist narratives include descriptive passages which explain the way in which narrated incidents are temporally and/or causally related; Coetzee calls this the "scene-setting and connective tissue that the traditional novel used to find necessary" (Coetzee, Doubling 59).
} 
critics have argued, suggest the fantastical or non-factual status ${ }^{87}$ of at least part of what Magda relates.

For some critics, Briganti argues, "the discontinuities in the narrative and the blurring between factual and imaginary reality have often been regarded as an irritating sign of Magda's insanity" (34-5). Sheckels, for example, argues that, "if the event does really occur (is not just a projection of her insanity), she is again struggling with language as she tries to transform act to artefact" (204). Foregoing accusations of "insanity," Rody argues that "by repeatedly restaging the event in successive entries, Magda undercuts our belief in the reality of the rape" (Rody, 175). Gallagher suggests that Magda simply "fantasizes that Hendrik will rape her" (94). The "inconsistencies" (Gallagher 106) within the section of text with which I'm herein concerned include variant consequences of the actions concerning an assault with a fork: first Magda claims that when she 'lunges' at Hendrik with a fork, "The tines scrape his shoulder, probably not even piercing the skin" (113); in the next section her uncertainty ("probably") is dropped and she iterates that Hendrik's "skin is not even pierced" (114); a few pages and sections later, however, she recalls that "Fingers grip the spine of a fork, the tines flash out, plunging through the patched shirt, ploughing through the skin. Blood flows" (117). Following the fork incident, two different sets of action are described: first Magda claims that "he exclaims in surprise and hurls me to the floor" (113), but on the next page a variation in phrasing has her narrate that "he sucks in his breath with surprise and hurls me against the wall" (114). Once the scene shifts to the bedroom, Magda gives two variant accounts of the removal of her clothes, first stating that Hendrik "forces me to undress" (115) but next suggesting that Hendrik in part undresses her: "Pulling off my pants," she notes, "he rips them on the shoebuttons" (116).

These differences are somewhat jarring, upon a first reading; the single narrator's variation of facts and phrasing undermines the conventions of literary realism which encourage readers to accept a narrator's rendition of events as reliable. However, when the differences are isolated (as above), they begin to seem quite trivial: is the reliability of Magda's narrative (the sense that it refers to events that actually, diegetically took place) thoroughly undermined by her failure to consistently determine whether or not the fork pierced skin, whether she was thrown against the wall or floor, or whether Hendrik had a part in the removal of her clothes? The previous paragraph reads like a court transcript of the speech a lawyer without a very strong case might make: the speech of someone desperately

\footnotetext{
${ }^{87}$ In terms of diegetic reality.
} 
grasping at any minute fault line in a witness' testimony in order to try to refute it. In the courtroom, the drawing of attention to these fault lines might in fact be sufficient to generate reasonable doubt toward the claims of that witness. In the novel, though Magda's narration also encourages readers to doubt its reliability, it is pertinent to remember that her attestations are not uttered within a courtroom setting and to note that our role as readers need not necessarily be akin to the role of prosecutor nor jury member, that we need not necessarily approach the narration as though it were testimony.

Derek Attridge suggests that most of Magda's narration can be considered a reliable representation of diegetic events if only certain passages are relegated to the domain of fantasy, claiming that "the realist narrative can be saved, however, if we assume that the two rapes are another example of Magda's fantasizing" ("Modernist Form” 27). Josephine Dodd, however, takes issue with the idea that the novel itself provides proof to which the reader can refer to support claims that certain statements are more diegetically factual than others: "the ontological status of the text," Dodd argues,

is such that there is no certainty about the locus of the real 'I' that negates all the other 'I's' by relegating them to the status of fantasy. The 'I' in one of the discontinuous narratives is as authoritative as the ' $\mathrm{I}$ ' in another .... Any naturalization of the text which privileges one of the 'I's' over another is of necessity an extra-textual predilection of the reader based on the reader's attitude .... one wonders at the ease with which some critics have been able to state that one sequence of events is real and another fantasy. (“Naming" 157)

My own reading agrees with Dodd's assertion. One cannot conclusively determine what, in this novel, is diegetically factual or not. Magda sometimes makes reference to her own writerly tendency to describe scenes in which she has not been involved, ${ }^{88}$ but such remarks

\footnotetext{
${ }^{88}$ In section 88 Magda describes a sexual encounter but indicates - via her use of the conditional tense and via the inclusion of a qualifying statement - that she has merely imagined what she describes. In this section she describes an encounter with an unspecified man whom she would "guide to the right hole, rendered penetrable with a gob of chicken fat from a pot at the bedside, and endure the huffing and puffing of, and be filled eventually, one expects, with seed by, and lie listening to the snoring of, till the balm of slumber arrive. What I lack in experience I plainly make up for in vision; if the commerce of men with women is not like that it might
} 
do not pepper her descriptions of the encounters with Hendrik; minus this self-reflexive 'incrimination,' the narration herein offers no definitive proof of whether the events described are fantasised by Magda or not.

Apart from disagreeing with Attridge on the defensibility of relegating certain passages to fantastical status, I don't feel impelled to assume that the fault lines in this portion of Magda's “disquieting” narration render her account of events necessarily antirealistic or unreliable. I don't wish to argue that everything Magda says diegetically transpired - to argue, that is to say, that her narration is akin to a testimony proved sound beyond all doubt - but to admit that I cannot know the extent to which her narration is, say, reliable or fantastical. In the face of this inability - and taking into consideration my desire to avoid the gauging of her narration as though I were assessing the extent to which it can be considered proof of diegetic fact - I offer her, as it were, the benefit of the doubt. My analysis asks: how might the whole of Magda's narration be interpreted as potentially (albeit inconclusively) reliable, if we afford each of her statements the same degree of authority, as Dodd has suggested we must?

Magda's inconsistent, discontinuous narration might, for example, be interpreted as a means by which the novel references a relativist and mutable sense of reality and portrays how imagination is involved in the activity of remembering. ${ }^{89}$ Magda's narration is not, I have argued, delivered in the service of proof-rendering (a service that testimonies delivered in a courtroom are elicited to fulfil). Perhaps many readers conventionally or habitually approach novels as though they were transcripts of testimonies delivered from the witness stand, and expect, correspondingly, that they ought to offer us (at least the illusion of providing) a single, reliable account of diegetic events. My argument, however, is that Magda's narration represents a certain take on the motions of memory - for example, by presenting a series of "meditations" which are concerned, Gallagher argues, with "the activities of the mind" $(82)$ - rather than abiding by the conventions of courtroom testimony

as well be" (46). This section offers an example of the manner in which Magda sometimes explicitly identifies certain passages of narration as imagined scenarios. If the descriptions of the encounters with Hendrik are read as fantasy, it is unclear why they lack the explicit indications of fantastical status which Magda provides elsewhere.

${ }^{89}$ I interpret Magda's narration as 'memory' even though she narrates for the most part in the present tense. Gallagher offers a similar assessment of Magda's narration, arguing that it seems "accurate to speak of the numbered sections as segments of her thoughts, or meditations. She does not write retrospectively, like Jane Eyre, looking back on her life and understanding its events in light of some coherent order. Rather, she writes 'to the moment' [...]. As Magda thinks about her life, in a text emphasizing that act by its use of the present tense, she creates or recreates that life" (82). I further discuss my interpretation of Magda's narration as presenttense memory in subsequent paragraphs. 
(another format in which the stuff of memory is given narrative shape). The differing statements I referred to above - which occupy Magda's initial descriptions of her sexual encounters with Hendrik - can be read as a transcription of Magda's mental engagement in the activity of trying to remember what happened: the descriptive accounts generated thereby are contingent upon what she is able, within the course of each attempt, to remember, supplemented by imaginative material based, it would seem, on what she deems would have been likely outcomes. In her first account of the assault with the fork, her "probably" indicates a gap in knowledge, suggesting that she does not know or did not see whether the fork actually pierced Hendrik's skin. The two, subsequent, differing accounts (the fork does not pierce the skin; the fork ploughs through the skin and blood flows) can be read, thus, as her mental rehearsing of two possible outcomes: an attempt to imagine an outcome which, as her "probably" indicates, she did not fully perceive or does not clearly remember. Whether she is thrown against the floor (113) or the wall (114) may also be read as an indication of an action whose outcome she does not fully remember or did not fully perceive. The fact that she was "hurled" is consistent; ambiguity surrounds only her recollection of the surface against which she landed. Perhaps she simply does not remember what surface she struck, or hit the intersection of wall and floor, or was hurled twice; similarly, the differences regarding the removal of her clothes might indicate that she can't remember quite how her clothes were removed, was ordered to remove her clothes by Hendrik but had her pants ripped off by him, or is in fact collapsing into these passages actions recalled from separate occasions.

Insofar as they cast, as I am suggesting, uncertainty upon Magda's ability to eidetically conjure experienced events (as though they transpired as unequivocable, isomorphically imitable phenomena) in later narrative recollection, these passages of narration thus deviate significantly from the purpose served by Lucretia's account of the rape in (particularly) Shakespeare's versions of that story. For that narrative's internal readers, Lucretia's account of the rape serves as something akin to testimony: it functions as a record of events, presented to a jury of men empowered either to punish her or to enact revenge on her behalf. For the narrative's external readers, Lucretia's account appears to indexically represent the events which were narrated omnisciently earlier on in Shakespeare's version, creating the sense that her narration functions as a kind of ideal testimony, exactly 
referencing that which has been established (by the omniscient narration) as seemingly unequivocable fact. ${ }^{90}$

Magda's narration, on the other hand, is not directed at (nor evidently commissioned by) any internal reader, ${ }^{91}$ the premise of its being offered up (to a diegetic audience) as something akin to testimony is thus done away with. Moreover, no alternate (let alone omniscient) account is provided within the novel as counterpart to (or more authoritative version of) what Magda narrates; external readers are therefore disallowed the activity of measuring how well Magda's version of events stacks up against that which has been established as another (less or more reliable) account of diegetic reality. Magda's accounts, it therefore can be argued, are not calibrated to serve a testimonial function. I read them, rather, as passages that represent the process of memory; they can be read as representations, in fiction, of the extent to which an ostensible rape victim, in the process of remembering and imaginatively supplementing memory, may mentally narrate a series of differing, or contradictory, or incommensurate narratives of the rape in order to attempt to apprehend it.

One may note that I am reading these passages as memories though they are written in the present tense. I argue that the novel's passages can indeed be read as memories, if memories are understood not as static vignettes that exist monolithically in the mind, but as narratives which are continually regenerated and potentially rewritten as we (re)narrate them in the present. Formally, the repetitions that occur across the sequence of passages with which I'm concerned (i.e. impressions of what seem to be the same objects and events ${ }^{92}$ )

\footnotetext{
${ }^{90}$ As I argued in part one, Livy and Shakespeare's use of omniscient narration conceals their privileging of particular perspectives upon rape by presenting their diegeses as though viewed 'from above' by impartial narrators. This narratorial technique dissuades external readers from recognising that events are being narrated from "a specific position" (MacKinnon 658) that "creates the reality it apprehends" (MacKinnon 636). Translated into a legal context, I argued, these narratorial positions are equatable to "rape law's assumption that a single, objective state of affairs existed, one which merely needs to be determined by evidence" (MacKinnon 654).

${ }^{91}$ Magda iterates that she desires an audience, but claims not to have one. In the context of passages that recount dialogue exchanged between her and the servants, Anna and Hendrik respond to her only in minimal terms, which is to say by invoking the 'code' of master-servant relations (as when Anna refuses to call Magda by her first name, insisting on continuing to call her "Miss" (111")) or by expressing a disinclination to speak with her at all (as when, in response to Magda's questions, Hendrik simply "departs" (120)). Magda feels, despite the presence of people around her, that she has access to no one who might express interest in listening to her confessions, meditations, complaints, or attempts to express affection (nor to anyone who might reciprocate such communication). Much of her narration seem as though it is geared toward someone else's reception or response: she asks a plethora of questions, wondering for example "what is the point of my story?" (5), "What does one do with desire?" (124) and "Where, unless compassion intervenes, does the round of vindictiveness end?" (142). However, her complaints of audiencelessness suggest that, for example, her interrogative statements are addressed only - be it out of hope or rhetorical habit - to a hypothetical future readership

${ }_{92}$ For example: Magda mentions Hendrik's grabbing of her arm in passage 205 and 206; the fork is mentioned (as, variably, an object picked up by Magda, a tool with which she stabs or attempts to stab Hendrik, and a
} 
suggest the mental activity of compulsively, imaginatively returning to and rephrasing components of the same experience. Other parts of Magda's narration suggest that her repeated mental return to events is informed by her desire to determine the meaning of those events: she poses questions indicating that she wants to know, for example "Am I now a woman? Has this made me into a woman?" (117) and also wonders what meaning the event holds for Hendrik, asking "What is this man trying to find in me?" (117). If these passages represent narrated memory, then, the memories they render have not been 'laid to rest'; 93 rather, they are continually subject to re-interpretation and re-wording, in a process which compels their narrator to repeatedly, mentally 'return' to them. This is a process characterised by the circularity and repetition in relation to which, elsewhere in the narrative, Magda expresses discomfort; she refers to a sense of being trapped in some sort of teleological stasis, noting her fear that "there is no past or future, that the medium I live in is an eternal present" (127). This comment may be interpreted as a reflection upon her compulsion to repeatedly re-narrate past experiences, an activity which in a sense keeps the past continually present in Magda's mind: it is as if she seeks with each narrational effort to locate the definitive meaning and form of those experiences, but being unable to do this, cannot graduate from the project of narrating the past again and again.

If Magda's passages of narration are read as acts of remembering - in which remembering connotes a mental attempt to determine the order and meaning of experience (rather than the recitation of these aspects as though they were self-evident or conclusively determined) - then the adverbial expressions of uncertainty that recur within these passages

utensil whose tines are held by an unspecified agent) in 205, 206, 207, and 210; Hendrik "hurls" Magda in 205 and 206; similar elements of dialogue (i.e. the cry "'Yes!'”, the cry " 'No!'”, and the cry " 'Please!' " which appear sometimes on their own and sometimes in sequences of 2 or 3 repetitions) pepper passages 205, 206, and 207; Magda leaves her shoes on in passage 208 and, by implication, her shoes also remain on in 209 (she says that, "Pulling off my pants, he rips them on the shoebuttons"); Hendrik is described as having been "inside" Magda in 206 and as having "forced his way into" Magda in 209; Hendrik is described as "rocking" Magda in both 206 and 209.

93 Though I am using the term memory to refer to an ongoing process of re-narration, Magda uses it elsewhere to connote a type of narrative style - "the weave of reminiscence in the dozing space of the mind" (47) accessible to those for whom the shape and meaning of past experiences have been comfortably, immutably established (what I suggest with the idea of memories that have been 'laid to rest'). This method of remembering is inaccessible to her, she claims, arguing that "My life is not past," (47) a phrase meant, perhaps, to connote that the meaning of her past experiences, or even the precise manner in which they played out, has not yet been settled upon and cannot thus be recited as though it were definitively, irrevocably established. Mark Currie has argued that temporal distance, in first-person narration, can substitutively effect the kind of "distanced aperspectivity" (MacKinnon 658) conventionally associated with third person narration (especially of the omniscient variety): "temporal distance," in first-person narration, he argues, "substitutes for distance in the third person point of view" (119) noting that "the reliability of self-narration depends on temporal distance between the narrator and the narrated" (118). By using the present tense, Coetzee suggests, I argue, that Magda has not yet achieved distance from, nor categorical clarity upon, the content of her remembered experience. 
can be interpreted as indications of the frailty and limited perspective of memory, as well as further indications of her uncertainty regarding the meaning of what has (ostensibly) happened. Likewise, the differences between passages can be read not as variations that necessarily cancel out the diegetic factuality of what is described, but as different ways of describing that which the narrator cannot precisely remember and/or speculations upon that which she desires to know. In other words, Magda's expressions of uncertainty, her variant phrasing, and her inconsistent reporting of details suggest the blind spots in her recollection of and interpretation of events: instances in which she does not clearly remember the details of what happened and/or instances in which she did not have perspectival ${ }^{94}$ access to the cause or meaning of events. To these blind spots, I argue, she applies estimations of what possibly or probably happened.

Thus Magda recalls falling but is uncertain whether, in this moment, she partially or fully lost consciousness, stating "I am falling, perhaps even fainting" (114). This statement may also be read as an indicator of inexperience married to an estimation of the category of event to which the fall might belong: i.e. if Magda has never fainted before, she may ask herself (for whatever reason) whether her experience was constitutive of a faint. Other statements indicate limited ocular perspective combined with inexperience. At one point, Magda states, after Hendrik pushes his head between her thighs (116) that "I am soggy, it is revolting, it must be with his spit, he must have spat on me while he was there" (116). The estimative statements ("it must be", "he must have") with which she guesses at the cause of her sensations can be read as the result both of not having (literally) seen what Hendrik was doing and of having had no comparable previous experience in reference to which Hendrik's actions, and the corresponding state of her body, might be inferred.

These components of Magda's narration contribute to the novel's portrayal of memory as an unreliable, partial, and partly creative tool; this portrayal, I argue, forms part of what Wright terms Coetzee's greater interest in exposing "the fallacious reasoning that there can be any consistent notion of the "real"' (57). This is an alternate way of reading the adverbial expressions - in particular, Magda's frequent use of the word "perhaps" - that have led other critics to argue that Magda, in service to an overweening authorial instinct, invents what she narrates. Ian Glenn, for example, argues that

\footnotetext{
${ }^{94}$ With the idea of limited perspectival access, I mean to suggest the limitations of Magda's access to both ocular and mental points of view. That is to say, in the course of the encounters with Hendrik, she would not have been able to (literally) see events from a number of aspects (hence perspectival limitation in the ocular sense) nor would she have had access to Hendrik's unshared thoughts and intentions (hence perspectival limitation in the mental sense).
} 
The evidence of Magda's role of inventor of the text is clear

from the first section, where her 'Or perhaps' signals for the

first time ... the artificiality, the arbitrariness of the writer's

imagination. (123)

For Glenn, Magda invents and/or embellishes arbitrarily, because she cannot resist the authorial instinct to improve, or wholly re-invent, her story. He discusses Magda the inventor and Magda the rememberer of facts as though they are two distinct entities with competing purposes: "Magda the writer is reflecting on what the story needs," he writes, "while Magda the character reflects on her past" (Glenn 124). My argument is that, rather, Magda invokes imagination where memory and knowledge fail her, not as a crafty substitute for memory but as an instinctual supplement to it. Imaginative hypotheses blend with and extend her attempts to apprehend what she has experienced, rather than cancelling out, competing with, or obscuring her memory of the 'real.' Rather than an arbitrary inventor of artificial memories, I read Magda as a narrator who is hyper-aware of the varying degrees to which her imagination becomes involved in all acts of memory. Her awareness of this characterises her narration not as arbitrary invention but as recollective prose suffused with a self-reflexive sense of "the inextricability of fantasy and reality" (Briganti 34). This is one example of the way in which Coetzee's novel moves, more generally speaking, away from the idea of narration as a "word-mirror" $" 95$ of experience whose pretence is to indexically reproduce reality in language. Coetzee's novel disallows readers from taking for granted the idea that the names and meanings of diegetic events exist, for Magda, or for anyone, outside of the process by which those events are imagined, re-imagined, doubted, and/or assigned names and meanings (which, in turn, may later be revised). ${ }^{96}$

\footnotetext{
${ }^{95}$ The term "word-mirror" is used by the title character in Coetzee's novel Elizabeth Costello. Delivering a lecture entitled "What is Realism?" (16), Costello argues that " "We used to believe that when the text said, 'On the table stood a glass of water,' there was indeed a table, and a glass of water on it, and we only had to look in the word-mirror of the text to see them. But that has all ended. The word-mirror is broken, irreparably, it seems [. . .]. The words on the page will no longer stand up and be counted, each proclaiming 'I mean what I mean!'” (19).

${ }^{96}$ Whether, as readers, we ever actually believe that a story's events exist 'somewhere' independently of the descriptions provided by characters in the narrative discourse, some narratives more than others support the entertainment of this belief. Shakespeare's The Rape of Lucrece, for example, presents us with an omniscientlynarrated tableau of an event (the rape scene), which is also later recounted by someone who was involved directly in that event (Lucrece); the implication is that Lucrece's description of the rape (however reliable) is a reference to set of events that exist independently of later description (even if they are thought to only be retrievable or reproducible by means of later description). Shakespeare's narrative thus prompts a certain
} 
Alvise Orlandini, in an article discussing manifestations of repetition compulsion in a trauma victim, cites a theory of memory that concurs with my interpretation of Magda's narration. "According to [Gerald] Edelman,"97 Orlandini writes, "memory is not a permanent registration in the brain, isomorphic to past experience" (527). Thus, the inconsistencies in Magda's accounts of what seems, I argue, to be the same event suggest that experience does not, in the moment(s) of its occurrence, 'imprint' its narrator with a consultable, immutable, itemised mental tableau of what has been experienced, in consultation with which later narration functions isomorphically. Instead, Magda's narration suggests that the components of experience become itemised - i.e. assigned names and, by extension, meanings - when, at a later date, and potentially under the influence of changed context or agenda, they are remembered / narrated. Edelman, paraphrased by Orlandini, refers to this process as "a dynamic reconstruction related to context and defined by categories" (527). ${ }^{98}$

Part of what drives Magda's analytical narration, I contend, is a desire to determine the taxonomical identity of what she has experienced. In pursuit of this task she enacts the process referred to by Orlandini as 'transference,' a process by which new experiences prompt cognitive consultation with categories of past experience, in order for taxonomical identity to be assigned to that which is remembered. Via transference, we draw lines of relation between the type of event that we are experiencing now and the types of events that we claim to have experienced in the past. "Finding something new," Orlandini argues,

produces a re-transcription of the event in a new context.

What is stored in memory is not a replica of the event but the potential to refind the category of which the event is a member. Transference is a way of imposing on a new object an old category with the compulsion to find a perceptual identity between past and present (528).

The mental activity of transference thus prompts the re-imagining of things prior to the spatio-temporal confines of a new event: memory references the cumulative extent of one's

imaginative support for the idea that experience exists - as though preserved or watched over by the impartial, incorporeal witness to whom the omniscient narration is attributed - independently of its later descriptions, hence supporting the idea that memory is a process of indexical or isomorphic reproduction.

97 Orlandini makes reference here to Gerald Edelman's book Neural Darwinism.

${ }^{98}$ This idea thus again justifies my theory that the novel uses present tense to convey acts of remembering: the choice of tense supports the theory that memories are always (re)created in present terms, as we speak them. 
experience in order that one's understanding of previous experience might serve to determine, by association, the taxonomical identity of the new. Therefore, the theory of transference also suggests that our perceptions of current events will vary, person to person, depending on the archive of categorical experience to which we individually take recourse. Similarly, our own perception of an experience may alter over time depending on other experiences we undergo which are perceived to correspond to, or are considered to re-define, the category of event to which the original experience is/was considered to belong.

The narration of In the Heart of the Country suggests both that Magda assigns names and meanings to her memories in consultation with her own particular archive of experience and that these names and meanings are subject to change (not because they are necessarily incorrect or non-factual but because they may be appended to phenomena whose particular elements and/or meanings are multifaceted and/or unclear to their narrator). Magda's narration of the encounters with Hendrik, for example, involves the referencing of more than one type of event: she reads the sensations of the encounters in terms of their likeness to events of which she has seems either to have had direct experience or with which she has otherwise made second-hand acquaintance (i.e. via, say, witnessing or reading). Evidently, she perceives on an intellectual level that this encounter with Hendrik is sexual, ${ }^{99}$ but she also compares the tactile, physical aspects of the encounter to other sorts of events.

In part of her narration she instead describes the event as surgery, explaining that "Things are being done to me, I feel them far away, terrible incisions, dull surgery" (115). Later, in section 210, she recounts the event in staccato sentences, omitting attributive pronouns and describing major aspects of the experience without explicitly characterising them as sexual: the encounter, she considers, consisted of

So many tiny events, acts, movements one after another, muscles pulling bones this way and that .... Fingers grip the spine of a fork, the tines flash out, plunging through the patched shirt, ploughing through the skin. Blood flows. Two arms grapple, the fork falls. A body lies on top of a

\footnotetext{
99 'Sex' (or variations like 'this sexual experience') would seem to be the term gestured to by Magda's repeated, empty pronouns: the 'what', 'it', 'that', and 'this' in phrases such as "as for what happens next, I do not even know how it is done" (114), " "No, please not, please, no that, only not that'" (114), "there is no pleasure in this" (114), "Is this finally how people do it?" (115), and "Let it stop, let it stop!" (115). The comparison of herself to a female dog in heat (114) indicates, also, her sense of the encounter as sexual.
} 
body pushing and pushing, trying to find a way in, motion

everywhere (117)

Up until the last sentence, the series of events described herein might easily be interpreted as components of a violent but non-sexual encounter, such as a physical fight. Even the last sentence, when read in relation to what precedes it, 'frames' the inferred sex act as, primarily, an adjunct to violence: as, for example, an allegorical answer to the stabbing fork (one invasive injury is met with another) or as a continuation of the violence established with the stabbing (the forced entry of the fork into the body escalates into the forced entry of one body into another). Here, and elsewhere in these passages, Magda's repeated mentioning of the incident with the fork (an instance of violent, but not explicitly sexual, assault) suggests that she - in enumerating the events that comprise this experience - considers the encounters to consist largely of non-sexual conflict. ${ }^{100}$ Fittingly, some of Magda's dialogue to Hendrik in these passages indicates that she 'names' this encounter not as rape but as another act of assault or angst in a series of such acts, waged against her by people who loathe and blame her. Thus, in reference to her (female, white, South African, apartheid-era) archival, contextual frame of reference she interprets Hendrik's actions as manifestations of his (and 'his people's') familiar anger toward her, crying to him

'You only want to hurt me all the time .... You people don't

know where to stop! Stop it! Don't do that, you're hurting

me! Why do you hurt me so much?' (115)

Clearly, Magda's taxonomical apprehension of her experience is enacted in consultation with her particular context, identity, and set of experiences; this forms another component of what I mean when I say that Coetzee's novel deviates from the idea of literature as 'word-mirror' of experience. The idea of narrator as mirror - an impartial, material reflector of the world at hand - obscures the impact that our own biases and histories bear upon our narration of (our assignment of names and meanings to) experience. Coetzee's narrative, rather than obscuring

\footnotetext{
${ }^{100}$ Magda's narration poses the question of whether the sexual aspects of the encounters should be subsumed under an understanding of the event as 'violent conflict' or whether the non-sexual violence should be considered as one part of the event cumulatively understood as 'rape.' Much has been written, in a similar vein, on the subject of the taxonomy of rape, especially as it applies to legal definitions of rape as punishable crime; Michel Foucault's comment that rape should be legally classified as an assault on par with any other -i.e. not singled out as a specifically sexual offense - has, in particular, been widely responded to by feminist critics. (See Foucault, Politics 200-205).
} 
these biases, highlights the central role they play in the process by which we taxonomically interpret our own experience to ourselves and/or to others.

Coetzee's division of the narrative into numbered sections - "quite brief sequences," the author calls them, "which are numbered as a way of pointing to what is not there between them" (Doubling 59) - functions well as a structural platform for (what I am arguing is) the portrayal of a narrator's repeated mental attempt to taxonomically comprehend (ostensibly, diegetically) experienced events. The novel's formal emphasis of "what is not there" between these (and indeed all of the novel's) passages suggests that the novel offers no precedent for a reading of these passages that presumes their sequential chronology: if these passages are interpreted, for example, as diary entries, we cannot know how much time elapsed between them, whether they refer to events in the same order that those events occurred, or whether each passage refers to an isolated event (which is not re-presented later or previously, in alternate terms). Conspicuously absent from In the Heart of the Country are the descriptive segues from scene to scene that describe the temporal and/or causal relationship between passages of narration: "the kind of scene-setting and connective tissue that the traditional novel," Coetzee claims, "used to find necessary" (Doubling 59). The omission of this "connective tissue" in In the Heart of the Country indicates that we are not, I argue, reading a conventionally realist account of a spatio-temporally framed narrator who ponders things (for example, 'I Magda, was sitting in my room at the turn of the century when I had the following thoughts'). Rather, I argue, the novel comprises a fictional representation of the narratorial by-products of Magda's acts of remembering, severed from the kind of spatiotemporal contextualising which might otherwise concern itself with when, where, and in relation to what these passages were narrated. The omission of "connective tissue" lends a bewildering effect to the book's staccato march of passages, an effect that might loosely be compared to the act of browsing through a book of photographs unaccompanied by text or captions: neither the chronology nor the juxtapositional logic which informs their organisation is confirmed for external readers / viewers, a confirmation which might assuage our discomfort with the images presented or at least explain for us why they are there.

Coetzee has argued that the "fundamental influence [of] film and/or photography" (Doubling 59) informs the novel; that

If I had to give examples of the kind of film whose style imprints In the Heart of the Country, I would cite a short film by Chris 
Marker called La Jetée and the film The Passenger ${ }^{101}$ [. . .].

What impressed me most about films like these was, paradox-

ically, what they could achieve through stillswith voice-over

commentary: a remarkable intensity of vision. (59-60)

Of course, Coetzee's book is not equivalent to a film of stills overlaid with narration; photographic images are, after all, materially available for analysis, in precisely the way that I have insisted that experience (actual or diegetic) is not. However, through repetition, and, as I have argued, the generation of a sense that the narrator is returning again and again to the study of the same or similar events, Magda's narration lends her subject matter an aura of stasis, of non-progression; if the experiences which Magda narrates do not exist independently of her narration (i.e. as still vignettes preserved materially, like the photographs in the films mentioned above), then her narration at least suggests an intense desire for her memories to assume tangible shape and definition. If the "intensity of vision" referred to by Coetzee above is taken as a metaphorical phrase for analytical scrutiny, then one can certainly argue that Magda's narration achieves an "intensity of vision" toward the objects of analysis which it seeks to hold in thrall.

In the Heart of the Country, this is all to say, brings to the table something that the Lucretia narratives do not: a questioning of the assumption that experiences 'announce' their categorical identity to us as we experience them and as we remember them (and that others will/are able to perceive experiences in a manner identical to us, if and when they are presented with the same set of events or with representation(s) of those events). Magda's evolving sense of the encounter's ${ }^{102}$ 'identity' (its name(s) and meaning(s)) is determined in consultation with the range of her previous experience and knowledge and is contingent upon the comparisons that she is able or wont to draw. This contrasts dramatically with Shakespeare's Lucretia narrative, in which Lucretia's encounter with Tarquin is recognised, defined, and categorised as rape by the omniscient narrator and prosopopoeic environment, whose observations render Tarquin and Lucretia's taxonomical diagnoses of the event secondary to and impartially mimetic of the process by which the encounter, as it transpires, self-evidently indicates its definitive identity to the world. In contrast, Magda's descriptions indicate that, because of who she is and what she knows - and because her experience is

\footnotetext{
${ }^{101}$ A film "put together by colleagues of Andrzej Munk after Munk's death from sequences he had completed plus some stills" (Doubling 60)

${ }^{102}$ That is to say, the encounters which have been interpreted as Magda's rape(s).
} 
something that she has to apprehend internally (which is to say, mentally, within the scope of her own experience and knowledge, and, also, based upon her own detection of sensations inside her body inaccessible to anyone else), rather than something that announces its own name to the world - the encounters with Hendrik may simultaneously be, seem, or mean different things.

This approach to reading the passages in which Magda initially describes the encounters with Hendrik dovetails with MacKinnon's call for a rethinking of rape-related "legal process as one involving a choice between incommensurate meanings rather than one of uncovering a (temporarily hidden) fact, the Truth" (MacKinnon is paraphrased in Rooney 90). MacKinnon's point is that, in a judicial setting where incompatible versions of an event are asserted by appellant and defendant, these versions may be concurrently true rather than mutually exclusive because (for example) many women are "violated every day by men who have no idea of the meaning of their acts to women" (653). What I have argued above is that the negotiation of potentially incommensurate meanings and memories may also occur for the individual herself who attempts to apprehend or narrate an ostensible rape experience. ${ }^{103}$ In the Heart of the Country explores the idea that, for Magda herself, the sexual encounters with Hendrik are made up of potentially incommensurate and/or incomplete memories and meanings.

\footnotetext{
${ }^{103}$ My reading of rape in In the Heart of the Country is contextualised within a reading of the rest of the novel which posits that the mental apprehension of all experience involves, to some extent, the individual's negotiation of multiple and possibly incommensurate meanings. As, here, I am focussing primarily on the novel's representation of (ostensible) rape, I give rape as an example of an event which may assume different manifestations and meanings within the imagination of one person involved, but in doing so I do not mean to suggest that rape is the only event that may involve this process.
} 


\section{CHAPTER SIX}

\section{The Abuse of Pleasure}

In the first six of the eight passages in which Magda initially describes her sexual encounters with Hendrik, the frailty, the perspectival limits, and the imaginative elements of memory are illustrated: Magda describes the encounters repeatedly and variably, in what can be described as a record of a mind engaged in remembering and narrating an experience whose constituent parts are, by her, patchily recalled, of uncertain meaning, and/or eligible for more than one name (be it 'fight', 'rape', or 'surgery', for example). Despite the variation amongst these passages, however, and the idea that they imply ambiguities in Magda's memory, her expressions of resistance to Hendrik's actions in this sequence - which are indicated via the description of physical resistance ${ }^{104}$, the citation of dialogue in which she attempts to refuse or dissuade him ${ }^{105}$, and her portrayal of her inner feelings of repulsion and non-consent during the encounters ${ }^{106}$ - are unmitigated.

However, in the wake of the encounters in kitchen and bedroom, parts of Magda's narration begin to suggest a more ambiguous response to Hendrik's actions. In section 210, lying beside the sleeping Hendrik, Magda's hand "covers his man's part, held there by his hand" (117), and then, at the end of section 211, she adds that "I too am falling asleep as my fingers, covered by his sleeping fingers, begin to learn to caress this soft thing" (118). In 212, when Hendrik awakes, she, surprised, finds herself speaking to him gently, saying " 'You have been sleeping.' They are my words, soft, from me. How strange. They just come.

\footnotetext{
${ }^{104}$ Magda tells us that "I struggle against him " (114); that "his fingers come up between my legs. I grip as tightly as I can to keep them still" (114); that "He parts my knees by force and I clamp them to again, time after time after time" (116); that "He has forced his way into me" (116).

${ }^{105}$ Magda cites herself as saying to Hendrik " 'No, please not, please, not that, only not that, I beg you, Hendrik" (114), " 'You are hurting me ... please ... please stop ...'” (115), and " 'Stop it! Don't do that, you're hurting me!" " (115), amongst other repeated cries of " "No" " $(114,115)$.

${ }^{106}$ Describing the experience, Magda says that "something is going limp inside me, something is dying" (114); that "I am faint with fright, there is no pleasure in this" (114); that "I am nauseous with fear, my limbs have turned to water. If this is my fate it sickens me" (114-15); that "I sob and sob in despair" (115); and that "I cry, there is no end to the humiliation" (116).
} 
'Please don't be cross anymore'" (118). A few pages later we read that "In the small hours of the night Hendrik creeps into my bed and takes me. It hurts, I am still raw, but I try to relax, to understand the sensation, though as yet it has no form" (120). Alongside these expressions of what has been interpreted as acquiescence or even willingness, ${ }^{107}$ these sections remain peppered with reiterations of the hate and humiliation Magda also feels in reaction to the encounters with Hendrik. She attests for example that "Everything dies in me when I have to raise my ugly rear to him" (122), and, later, tells Hendrik "you hurt me. Do you know, you have the power to hurt me, and you do it every time" (128).

Some critics have noted the novel's presentation of a range of contradictory attitudes expressed by Magda towards Hendrik - her welcoming of his advances, on the one hand, and her sense of humiliation and hurt, on the other - and generally attribute this to the comingling of the narrator's expressed, pre-existing desire to establish communion with Hendrik and her abhorrence of the terms in which he instigates sexual contact with her. Eagerly, but unsuccessfully, Rody and Gallagher argue, she tries to interpret his actions as the kind of intimate exchange or union for which she has been yearning. "Magda," Rody argues, "tries pathetically to interpret Hendrik's act of hatred as an act of love" (175). Gallagher posits that "Magda acquiesces to his new role, longing to believe that it is the path to intimacy for which she has been searching" (102) but that "neither her acquiescence to Hendrik's rape nor her perseverance in talking to Anna bring her the intimacy for which she longs" (103). I think that the notion of Magda's 'acquiescence' to Hendrik is open to alternate analysis; the seemingly complicit reactions I mentioned above don't, necessarily, merely represent the perpetuation (despite new circumstances) of her pre-existing desire for communion with Hendrik, but can rather be interpreted as responses brought on in part by trauma itself (the trauma, that is to say, of the violent, sexual encounters with Hendrik, and also, perhaps, a more nebulous trauma - involving historic familial or societal conditions of abuse - in which Magda seems to have been involved).

In this chapter, I will reference a number of psychoanalytical theories which deal with victims' traumatic responses to rape. These theories posit a number a ways in which women's apparent consent or acquiescence to ongoing abuse might be explained. ${ }^{108}$ As I noted in the introduction to this thesis, my objective herein is not to psychoanalyse Magda,

\footnotetext{
107 Gallagher argues, for example, that "Magda acquiesces" (102) to sex with Hendrik.. Attridge claims that Magda is "half inviting Hendrik to have sex with her" ("Modernist Form" 25).

108 Explained, that is to say, as traumatic response to undesired trauma, rather than as an indication that the victim does indeed want the abuse to continue.
} 
who - I recognise - is a literary character, termed by one critic a "a mere trope" (Rody 163), rather than a living, breathing subject. Rather, I aim, by describing these theories, to argue that expressions of apparent consent need not necessarily be read as evidence of unmitigated acquiescence to abuse. I contend that the tendency to read apparent consent as an indication of unmitigated acquiescence to abuse extends from the belief that 'true' rape victims react to ongoing rape by persistently, continuously, and unequivocably demonstrating non-consent. ${ }^{109}$ In order to suggest that other readings of apparent consent are plausible, a review of the relevant psychoanalytical literature is called for.

Consent, or apparent consent - indicated by a range of behaviours referred to variously as non-resistance, assent, acquiescence, or yielding - has been identified in sociological and psychological literature ${ }^{110}$ as a frequently cited response to rape, especially to ongoing acquaintance rape, amongst sexually abused women. As I will explore more fully below, responses to rape that fall into this category may range from aversion ${ }^{111}$ to repetitivecompulsive re-exposure to abuse. The consequences of these responses for judicial definitions of rape and, more generally, for popular notions of what is indicated by apparent consent, are weighty; they undermine the idea, for example, that a rape appellant's nonconsent to sex must have been unequivocable (and, preferably, demonstrable) in order for her accusation of rape to stand. If a victim's expression of partial consent, assent, acquiescence or yielding to rape is conventionally thought to undermine the authority of the accusation that

\footnotetext{
${ }^{109}$ Susan Erhlich terms this belief the "utmost resistance standard" (65). As an example of its application within rape-related jurisprudence, she notes that "Until the 1950s and 1960s in the United States," she notes, "the statutory requirement of utmost resistance was a necessary criterion for the crime of rape (Estrich 1987); that is, if a woman did not resist a man's sexual advances to the utmost, then rape did not occur" (65). Erhlich argues that similar requirements applied to women involved in American rape cases in the nineteenth century (66). She cites S.J. Schulhofer, who - discussing these earlier cases - notes that " 'to make sure that women complaining of rape had really been unwilling, courts required them to show physical resistance, usually expressed as 'earnest resistance' or even 'resistance to the utmost'" (66). Schulhofer, Estrich states, "goes on to provide examples of specific judicial decisions in the late nineteenth-century and first half of the twentieth century in the United States, which invoked resistance standards in ascertaining that rape did not occur" (66). "While [Susan] Estrich," Erhlich concludes, "says that the "utmost resistance' standard was generally replaced by a 'reasonable resistance' standard by the 1950s and 1960s in the United States, she also cites decisions as late as 1973 which contend that 'rape is not committed unless the woman opposes the man to the utmost limit of her power" "(66).

${ }_{110}$ See, for example, Warshaw (1988), Santello, M. D., \& Leitenberg, H. (1993), and Graham et al. (1995).

111 I use the term 'aversion' here simply to connote the kind of behaviour that might be interpreted as minimally consenting. Coetzee suggests this kind of behaviour in another one of his novels, Disgrace, when the protagonist David Luria (through whom the novel's third-person narration is focalised) comments upon the attitude of prone Melanie, a character with whom he has sex). During a scene in which - despite Melanie's exclamations of non-consent to his affections in this instance (24-5) - "He carries her to the bedroom, brushes off the absurd slippers, kisses her feet" (25), we read that Melanie "does not resist. All she does is avert herself: avert her lips, avert her eyes" (25). The narration states next that this is "Not rape, not quite that," (25) but there is a case to be made for reading this scene as rape, especially when it is described as something that, for Melanie, is "undesired to the core" (25).
} 
she was subjected to unwanted sex, I am suggesting that such expressions may also be correlated to coping strategies and/or responses brought on by exposure, or repeated exposure, to sexual abuse. As for its portrayal in literature, the idea of apparent consent as a coping strategy or traumatised response to rape poses an opportunity to invert popular convention: if the portrayal of the no-means-yes convention involves the eroticisation of refusal, the portrayal of the idea that yes-means-no might involve the traumatisation of consent. It might involve the portrayal, that is to say, of the mechanics of trauma that may inform a rape victim's utterance of 'yes' in the wake of (or as, itself, sign for) her 'no.'

In reference to In the Heart of the Country, Gallagher's use of the term 'acquiescence' demands, for a start, some critique. The term suggests submission-withoutcomplaint to a set of conditions or actions; a "quiet satisfaction" or "silent or passive assent to, or compliance with, proposals or measures" $(O E D)$. The emphasis on wordless submission in these definitions is key to my complaint that Gallagher's term is an insufficient descriptor for what Magda describes as her responses to Hendrik; Magda's responses consistently involve her speaking to Hendrik in order, she hopes, to instigate the exchange of both voices and glances. In passage 217 she entreats Hendrik to respond to her worries that she is an incompetent sexual partner, asking “ 'Am I doing it right, Hendrik?' ... 'I don't know anything about this, Hendrik - do you understand? All I want to know is whether I am doing it right. Please give me just that little help." "(120). Hendrik, here and in other parts of the narration where Magda makes conversational demands of him, does not answer; his refusal to engage with Magda in a discussion of their interactions culminates in a tirade of (unanswered) questions that Magda directs to Hendrik just before he and Anna leave the farm. Here she demands that he " 'Tell me! Speak! Why do you never say anything? Why is it that you take me every night if you hate me? Why won't you even tell me if I do it right?' '” (128). It is clear that Magda's reactions to sex with Hendrik never involve mute, satisfied submission to the extant terms of the encounters. Her responses are not indicative of acquiescence to conditions as they stand, but signal, rather, an attempt to alter the parameters of each encounter, and therefore, I argue, to change her relationship with Hendrik into something less threatening for her and more desired by her.

This is one way in which Magda's responses to Hendrik can be read as a sort of resistance to, rather than an act of compliance with, the rape(s). Given that Magda, according to her narration of events, has no control over whether and when Hendrik will demand (or 
withhold $)^{112}$ sex, she attempts to wrest control of the situation - her repeated rape - in a different way, by attempting to change the parametres of her relationship to her rapist so that she might transform their sexual encounters into something that is not rape. This reading diverts from the extant criticism attending to the novel but is consistent with research that has documented the responses of women to sexual assault (especially to repeat acquaintance rape). ${ }^{113}$ Read in consultation with a range of the literature in which women's responses to rape have been documented and analysed, there are a number of ways in which Magda's responses to Hendrik might be interpreted; one need not assume that her reactions to Hendrik indicate unmitigated acquiescence to the extant conditions of the sexual encounters.

Magda's contradictory responses to Hendrik are consistent with some victim responses cited in a 1988 report on a U.S. nationwide survey of rape victims' experiences and responses coordinated by Ms. magazine, psychoanalyst Mary P. Koss, and the [American] National Institute for Mental Health. This study offers evidence that raped women sometimes feel impelled - via re-exposure to sexual interaction with the perpetrator to cognitively ‘transform' rape into desired sex. The author of the report, Robin Warshaw, notes that the results of the study indicated that sometimes, after having been raped by an acquaintance,

a woman sees the man who raped her again in order to turn the rape into an experience of sexual intercourse that happened in the context of an ongoing relationship and, therefore, to make it acceptable. (63)

As an example of this Warshaw cites a woman interviewed during the course of the survey who explained her own self-initiated sexual re-involvement with her rapist after the rape as “ 'an attempt to sort of legitimize what happened' " (63).

\footnotetext{
${ }^{112}$ Magda notes that "some nights he does not come. I lie naked, waiting, dozing into shallow sleep, snapping awake at the first birdsong, the first aura of dawn. This too happens to women, they lie waiting for men who do not come, I have read of it" (121). The passage conveys an anxiety that hovers between a sense of Hendrik of lover and as rapist: it is not clear whether she dreads his approach or is eager for it. In either case, the common thread is that she has no control over whether or not Hendrik will come to her. This state of affairs - this lack of control - perhaps motivates her speculation that Hendrik and Anna can somehow sense or see her waiting, helplessly, in this manner: "Do the two of them see me like this? Do they point at me and smile and tiptoe about their business?" she narrates, adding that "I grind my teeth with shame" (121).

${ }^{113}$ That is to say, circumstances in which a woman is raped repeatedly by the same acquaintance.
} 
That rape victims should feel impelled to reframe an experience of unwanted sex as something acceptable or legitimate can be related to the findings of another survey of rape victims in which more than half of the women surveyed "felt ashamed of what happened, and $80 \%$ felt guilt connected to the incident" (Santello and Leitenberg 100). The sense of guilt and/or shame that seems to occur so prevalently in victims of rape may foster a victim's sense that they have colluded in, rather than been subjected unwillingly to, a rape; Warshaw notes, for example, that a raped woman may become sexually re-involved with her rapist and/or feel compelled to reframe her relationship with that rapist as a collaborative, coconsenting relationship - if she feels "tied to the man because of their shared 'guilty secret' " (64). In In the Heart of the Country, Magda evidently feels both ashamed of the encounters with Hendrik - noting that "I am humiliated; sometimes I think it is my humiliation he wants" (122) - and guilty, as though she is somewhat responsible both for Hendrik's actions and for (what she perceives as his potential) non-enjoyment of the encounters. Confessing that "I do not know what pleases him, whether he wants me to move or lie still" (121), she apparently blames herself for the apparent fact that he "stays with me more and more briefly, sometimes only for the minute it takes him to release himself inside me" (121). Her guilt also extends to a concern for how the encounters might impact upon Hendrik's wife Anna; thus, one night after "Hendrik creeps into my bed and takes me" (120) Magda is compelled to note that

Anna must on no account make up this bed in the morning. I must rub salt on the into the bloody sheets and lock them away, or else quietly burn them (120).

These statements accord with Warshaw's theory: Magda's expressions of shame and guilt in this section of the text are interspersed with statements that indicate her attempt to reframe the encounters with Hendrik as collaborative and co-consenting. Likening herself to a woman waiting for her lover to come to her (121) and wondering what she might do to please him (121) - Magda seems to want to wrest control of the encounters, to re-define her position as one in which she desires that which (in fact) she cannot control.

Warshaw's theory of re-engagement coping - which involves the victim's reinstigation of or willing involvement in subsequent sexual activity with the rapist as an attempt to re-contextualise rape as desired sexual encounter - thus offers a means of 
interpreting contradictory (and / or apparently consenting) responses to rape not as submissive acquiescence but as indications of an active effort to minimise the harm of, or to legitimise (in the face of shame and embarrassment) the occurrence of, that sex.

It is pertinent to my argument to note the possibility of identifying the portrayal of traumatic response in a literary narrative wherein the source trauma is not, itself, represented. ${ }^{114}$ Kathleen Scheel has argued, for example, that in Faulkner's Sanctuary though any direct depiction of the sexual abuse perpetrated against the protagonist Temple by her father and brothers is conspicuously absent from the text - one can read certain descriptions of Temple's behaviour, and certain passages of her dialogue, as portrayals of traumatic response (which are therefore taken by Scheel as indicative of source trauma). In other words, Scheel argues, it is defensible to say that Temple was previously ${ }^{115}$ sexually traumatised, even if this previous trauma is not explicitly described nor referred to in Faulkner's novel. A “psychoanalytic reading of [Temple's] patterns of speech and behavior," Scheel argues, "reveal[s] that incest is more than a threat or male fantasy and is instead a real victimization that she has previously experienced" (par. 4). Scheel takes issue with interpretations of Sanctuary that rationalise Temple's behaviour by claiming that she is simply "consumed by lust" (par. 23), citing as an example Robert Parker's argument that “ 'when Red rapes her, she loves it and wants more'" (par. 23). Convinced that certain grammatical cues ${ }^{116}$ - in the scene where Temple is raped by Popeye - represent a reference to previous trauma, ${ }^{117}$ Scheel interprets Temple's responses to Popeye and other sexual partners as manifestations of the psychological concept of Repetition Compulsion. Repetition

\footnotetext{
${ }^{114}$ By 'source', I mean to imply the first traumatic event or encounter that a character (ostensibly) experienced and to which subsequent trauma-based responses can be attributed, i.e. rather than subsequent events or encounters that enact the reprisal of traumatic response; by 'represented,' I mean to imply the depiction, in the course of a narrative discourse, of this first event or encounter, i.e. not the inferential depiction of it incurred via the representation of its later effects.

115 Which is to say, in a imaginary, inferred diegetic situation absent from the narrative discourse and temporally prior to the events of the story that are represented in Sanctuary.

116 "In what is certainly the most lurid event of the novel," Scheel writes, "Temple lies trapped in the corn crib" (par. 2). As "Popeye comes toward her," (par. 2) Temple shouts " " 'Something is going to happen to me!" ," adding " ' "I told you it was!' , " and " " 'I told you! I told you all the time!' , " (Faulkner qtd. in Scheel par. 2). Scheel notes that "It is not until Chapter twenty-eight that we learn that was 'is happening' is Popeye's rape of Temple with a corn cob, but there is 'Something' else going on in this scene, a mystery which is never revealed in its entirety in the novel. What 'was' happening? Why does Faulkner change the verb tense from 'is' to 'was'? Who is the 'you' to whom Temple refers?" (par. 2). Scheel eventually concludes that "Temple's victimization began not in the corncrib of Goodwin's barn, but much earlier in her 'crib' at home" (par. 26), arguing that Faulkner provides "ample psychological basis for reading Temple Drake's complex and seemingly contradictory behavior as an effect of a repressed, traumatic event, one which she is compelled to repeat and dreads to remember" (par. 29).

${ }^{117}$ Scheel's argument is conducted in the spirit of Diane Roberts' assertion that " 'it is hard to believe that what Popeye did with his corn cob was unchain the hidden nymphomaniac inside Temple" " (par. 23).
} 
Compulsion is another theory which explains rape victims' apparent complicity to (their) ongoing traumatisation as a defense mechanism brought on by victims' perception of the inevitable, perpetual recurrence of (variations of) that trauma. For instance, Scheel argues,

Temple believes that she cannot enter a room without men treating her as an object of sexual gratification. Her seemingly paradoxical behavior, on close reading, reveals the repetition-compulsion pattern in which 'a subject deliberately places himself in distressing situations thereby repeating an old experience, but he does not recall this prototype; on the contrary, he has the strong impression that the situation is fully determined by the circumstances of the moment.' (Laplanche and Pontalis qtd. in Scheel, par. 7)

Repetition Compulsion involves, in part, the previously traumatised person's generalisation $^{118}$ of abuser-victim dynamics: the process, that is to say, by which a person internalises the dynamics of an abusive situation to which they are exposed and assumes that these dynamics will be inherent to subsequent encounters which are perceived (by the victim) to belong to the same category of event as the situation in which those dynamics were learned. For example, Scheel argues that Temple - in reaction to certain stimuli that mimic the conditions of her source trauma ${ }^{119}$ - repetitively, compulsively prepares "for an event which she dreads and simultaneously anticipates" (par. 6). Sensing on some level that escape from the recurrence of this trauma is unachievable, "Temple," Scheel argues, "exhibits the trapped victim's acquiescence to the inevitable sexual violence that she has been taught to anticipate" (par. 13), attempting, via pre-emptive, placative indications of willingness, to temper the harm from which she (perceives she) cannot escape. The indications of apparent complicity that Temple, as such, exhibits involve a tendency to smile at those whom she perceives as potential attackers. Scheel argues that Temple's smile - described as an

\footnotetext{
${ }^{118}$ In psychological discourse, generalisation is defined as "the tendency for a learned response to a particular stimulus to be elicited by other stimuli that resemble it" (A Dictionary of Psychology).

${ }_{119}$ As an example of one of these conditions, Scheel mentions the presence of three or four men surrounding Temple, a situation which she claims "Temple will associate with her four brothers in her own not-so-Sweet Home" (par. 28).
} 
“ 'aching, rigid grimace'” (par. 14) and a " 'grimace of cringing and placative assurance'” (par. 14) - "can be seen," in these contexts, "as a learned behavior designed to mitigate the violence she anticipates from men" (par. 14).

Regarding the issue of what kind of source trauma might cause this sort of 'anticipation,' a number of psychological theorists, cited in Graham et al., have argued that generalisation effects can "be caused by chronic, recurrent childhood trauma" (4). I have suggested that the encounters with Hendrik represents the first occasion(s) in which Magda becomes directly involved in a sex act (a state of affairs which initiates, I have argued, her taxonomical comparison of the encounters to other event types such as 'fighting' or 'surgery'). Her self-characterisation elsewhere as "bitter vestal" (3), ${ }^{120}$ "miserable black virgin" (5), and "jagged virgin" (9), would also suggest that, previous to the encounters with Hendrik, she has not been (hypothetically, diegetically) directly involved in a sex act. However, there are critics who have detected suggestions of incest in the novel - Chiara Briganti argues that the novel contains "recurring references to a possibly incestuous relation with the father" (40) - or who argue, as Dodd does, that 'we' readers are "scripted by our dominant psychoanalytical discourse to identify her [Magda] as wanting to be seduced by her father" ("Naming" 159). Whether or not one infers a history of incest from Magda's narration, her behaviour - the manner in which she repeatedly places herself in harm's way, as it were - can be interpreted as comparable to the manner in which Temple "anticipates that men will continue to pursue her with sexual violence because that is her experience of the way they have acted in the past" (par. 6)

The potentially traumatic scenarios to which Magda repeatedly offers herself do not involve her direct involvement in sex acts, but, rather, seem motivated by her perceived exclusion from (and correspondent desire to be part of) instances of sexual and/or marital intimacy. ${ }^{121}$ Early in the novel she approaches the bedroom wherein her father and his "new wife" (1) ostensibly "cavort" (3), and from which, Magda claims, a "warm murmur from the great bed" (9) emanates; in front of this scene, Magda wonders "Should I go to them clothed?

\footnotetext{
${ }^{120}$ In reference to ancient Rome, the word 'vestal' connotes "a virgin consecrated to Vesta and vowed to chastity" $(O E D)$. Vesta, in Roman mythology, is "the goddess of the hearth and household" $(O E D)$.

${ }^{121}$ In fact Magda immediately precedes her use of the term "childhood rape" with the assertion that she is one of many "melancholy spinsters" who, "Wooed when we were little by our masterful fathers ... are bitter vestals, spoiled for life" (3-4); it thus seem plausible that, by "childhood rape," she means to connote a kind of exclusion from or denial of paternal love which somehow ruined her subsequent ability to engage in sexual intimacy with others as adult. Though this is a figurative use of the term 'rape,' it shares something in common with a literal definition of rape (i.e. forced engagement in an unwanted sex act) in that it represents an overriding of Magda's will (a denial of her desire for paternal love).
} 
Are they phantoms who will vanish when I touch them? .... I drop my clothes at the door" (9). This is not the sole occasion upon which Magda "stand[s] in the doorway, naked, asking" (9): later in the novel she again "stand[s] outside the door" (59) of her father's bedroom door (wherein, this time, he is ostensibly in bed with Hendrik's wife Anna). She taps on the door (59), asking

'Daddy ... Can you hear me?'

They are silent, listening to the enormity of their breathing. ${ }^{122}$

'Daddy, I can't sleep.'

They look into each other's eyes, his look saying, What must I do?, her look saying, She is not mine. (59).

Magda attempts to open the door to the bedroom but it is locked; she 'knocks' and then 'thumps' on the door (59) in an attempt to elicit a response. In a subsequent episode ${ }^{123}$ she does not approach the bedroom door but instead - wondering whether her father and Anna, in the bedroom, are "lying with bated breath, with two breaths bated, waiting for me to make my move?" (62) - rings the "dinner-bell" in the kitchen until, it would seem, her father is impelled to come and stop her (62-3). Magda also seems disposed to become involved in other couple's arguments (as well as in their scenes of conjugal (or extra-marital) intimacy). ${ }^{124}$ Though more obliquely, she seems as enthralled by Hendrik and Anna's "dogfight" (81) as she is by the activity in her father's bedroom; though she first tells Hendrik that "What happens between you and Anna is none of my business" (81), she soon becomes involved in the fight and admits that "there is exhilaration mixed in with my alarm" (82). Part of her motivation for becoming involved in the incident is an apparent desire to stand up for Anna, ${ }^{125}$ but once she is involved, she seems to conceive of the fight as a sort of

\footnotetext{
${ }^{122}$ Magda's assumptions about the thoughts and actions going on behind this particular closed door indicate that this is another instance of imagined omniscience (such as I discussed in chapter 4 of this thesis).

${ }^{123}$ It is unclear whether this (second) episode directly follows (i.e. in fabulaic chronology) that described on page 59, or whether an undescribed amount of time elapses between the two described incidents.

${ }_{124}$ As I argued in chapter 4, Magda evidently conceives of intimacy as something involving degrees of subjection and violence; it follows that scenes of intra-couple conflict would seem potentially as intimate, to her, as scenes of sexual involvement.

${ }^{125}$ Magda warns Hendrik to "beware" her involvement in the fight, should Anna claim that her husband has been cruel to her (81); she also refers to her involvement as an act of "standing up for the weak" (82).
} 
affectionate interaction between the three into which she is fortunate to have been included; when Hendrik releases her ${ }^{126}$ she notes that

I fall heavily on my backside, my palms are scorched by the gravel, my skirts fly in the air, I am dizzy but gay and ready for more, perhaps what has been wrong all these years is simply that I have had no one to play with (82-3).

As is the case with her involvement in the conflict between Hendrik and Anna, Magda's actions at her father's bedroom door (or down the hallway, in the kitchen) are, in the latter two scenarios I mentioned, met with explicit violence, seemingly designed to dissuade Magda from posing her entreaties. However - as she does in reaction to Hendrik above - Magda reacts to this violence in a way that, in part, suggests her desire for or appeasement precisely by that (purportedly) punitive violence itself. After she 'knocks' and 'thumps' on her father's bedroom door, for example, she claims to be made "content" (60) by her father's chastising treatment of her; in response to her, she narrates,

The lock snaps open. Through the crack his arm snakes out at me milky white above dark hair. Instantly he has my wrist in his grasp and crushes it with all the strength of that great hand. I wince, but I will never cry out. What sounds like a cascade of corn-shucks ${ }^{127}$ is his whisper, rasping, furious .... The great hand slides up my arm till it finds and grips my elbow. I am forced down and down; my head is against the doorjamb. I feel no pain. Things are happening in my life, it is better than solitude, I am content (59-60).

Subsequently, when her father returns (to usher her from the hallway into her own room), she claims in relation to herself that "What happens to this body I do not care. If he wants to stamp it to a pulp beneath his heels I will not protest" (60).

\footnotetext{
${ }^{126}$ He previously grabs and shakes her (82).

127 Incidentally, Magda's use of the term "corn-shucks" (60) here recalls, and may be read as a reference to, Faulkner's Sanctuary (in which the protagonist Temple is raped with a corncob).
} 
Magda's apparently complicit, sometimes enthused reactions to the violence with which her aforementioned actions are met concurs with Alvise Orlandini's understanding of repetition compulsion as a condition in which "extreme emotions," such as those invoked in the course of traumatic experience, are craved and sought out. Referring to the biblical story of Samson, Orlandini argues that

\begin{abstract}
Samson is in a psychophysical state of excitement from the power of his destructive fury, an excitement similar to an insatiable craving, which produces addiction. In fact $\mathrm{RC}^{128}$ can be considered a particular kind of addiction, not to substance but to extreme emotions such as strong excitement
\end{abstract} (Orlandini 529).

Orlandini's argument offers a way in which to plausibly explain the "exhilaration" (tempered by "alarm") that Magda feels in response to having become involved in Hendrik and Anna's dispute, and the reason for which she claims, in response to Hendrik's violent shaking of her (82), that she feels "gay and ready for more" (83). The "strong excitement" to which, Orlandini argues, repetition compulsion causes one to become 'addicted' is addictive because - according to research which he cites at length ${ }^{129}$ - "Powerful excitement decreases pain" and "retraumatization produces analgesia" (Orlandini 536). ${ }^{130}$ Magda's exposure to violence in the aforementioned scenarios indeed seems both to arouse in her a sense of "strong excitement" (hence her "exhilaration" (82)) and to produce an analgesic response: thus, in response to her father's forceful treatment of her, she claims to "feel no pain" (60). In recounting her father's reaction to her ringing of the dinner-bell, ${ }^{131}$ Magda's narration might again be read as a literary representation of analgesic response. In this passage she notes that

\footnotetext{
${ }^{128}$ Orlandini uses the acronym 'RC' to refer to repetition compulsion (525).

${ }^{129}$ For example, Orlandini references "a model of explaining RC, derived from animal research. When animals are under a [sic] unavoidable shock, they will develop stress-induced analgesia (SIA) if re-exposed to stress shortly afterwards" (531). Citing another study, he adds that " "seven out of eight Vietnam veterans with PTSD showed a $30 \%$ reduction in perception of pain when viewing a movie depicting combat in Vietnam .... This amount of analgesia produced by watching 15 minutes of combat movie was equivalent to that which follows the injection of 8mg morphine" "(531). Orlandini adds that the "experiments of Van der Kolk show that even in people traumatized as adults, re-exposure to a situation reminiscent of the trauma evokes endogenous opioid responses" (531). He notes that the release of endogenous opioids in trauma victims "produces both addiction and withdrawal symptoms just as happens with exogenous opioids" (531).

${ }^{130}$ Analgesia is defined as "Insensibility to pain; painlessness." (OED).

${ }^{131}$ By implication, Magda rings the bell in the middle of the night, or at another time when the house is "silent" and others "lying in bed" (62). She rings it continuously, the bell reportedly "making a thin continuous genteel tinkle" which graduates into a measure of tones comprising "four soft, four loud" (62).
} 
"I am hit a heavy blow on the head," adding that "The bell is torn from my hand" (62); she does not react to the violence by claiming that it felt "exhilarating" or otherwise gratifying to her, but does claim that "The blow does not hurt" (even though her "nose is bleeding" and she is "swallowing blood" (63)).

Orlandini argues that the analgesic effect of repeated exposure to (physically) painful stimuli extends to (the prevention of one's ability to feel) emotional pain. Of a particular patient of his, he writes

When she felt a desire for affection from her mother she managed to be beaten, and not for a masochistic pleasure.

In fact this produced a condition of emotional emptiness, of analgesia and the desire for love disappeared. (534)

This vignette recalls Magda's comments, in the wake of her father's violent reaction to her knocking upon his door. After having, as it were, "managed to be beaten" by him (in a series of events that occurred after she "felt a desire for affection" from him, indicated by her pleading entreaties at his door), her apparent "emotional emptiness" is expressed as an icy breeze that wafts, uninhibited, through her body. "I squat," she narrates,

against the wall opposite the door. My head lolls. From my throat comes something which is not a cry, not a groan, not a voice, but a wind that blows from the stars and over the polar wastes and through me. The wind is white, the wind is black, it says nothing. (60)

Similarly, some of her responses to Hendrik indicate an analgesic response brought on by the trauma of the ostensible rape: she comments in one passage that "my body has locked itself against him" (127).

The idea that Magda's apparent consent, to the violence she receives from her father and to the encounters with Hendrik, may constitute a literary portrayal of analgesic numbness brings me back to the question - posed in chapter five of this thesis - of whether the rape affords Magda any degree of communion with others (with, for example, Hendrik). At the end of chapter five I concluded that the rape constitutes a horrible figure for her extant idea 
of intimacy ${ }^{132}$ rather than affording her the ill-defined form of idyllic communion after which she longs. Here I might also add that - read in consultation with the theories of repetitioncompulsion and analgesic response discussed above - the rape, in an awful manner, mitigates the agony of Magda's painful, unattainable desire for communion with those around her. The persistence with which she tries to accommodate Hendrik - trying "to relax" (120), trying to make him " "feel happy" " (120), and lying "naked" in wait for him (121) - and with which she places herself in the path of violence suggest that these scenes may be interpreted as a literary portrayal of revictimisation behaviour. Orlandini argues that

all types of desires that are never satisfied (such as the desire for caring or nurturing, narcissistic desires, and so on) produce a deep frustration which can be calmed only by inhibiting or even cancelling the desire. In my opinion, the desire underlying $\mathrm{RC}$ is not mastery of trauma, but rather a desire for a more positive relationship with caring and acceptance .... the patient might destroy this painful desire and find relief from the conflict through analgesia produced by revictimization. In other words, I think that the aim of $\mathrm{RC}$ is the reduction of emotional pain through a well known and familiar behavior such as retraumatization. (536)

This is not to suggest a reading of the novel which posits Magda's desire to be raped. Rather, I am suggesting that it is plausible to read Magda's apparently analgesic reactions to violence and rape as indications of traumatised, rather than acquiescent, response.

Livy's and Shakespeare's Lucretia narratives can be said to omit from representation the after-effects of rape which are borne out, long-term, by the rape victim who expresses traumatic responses to subsequent stimuli. Lucretia's suicide - and the post-rape, transformative mutilations described in Greek rape narratives - remove the rape victim from the story, or transform her beyond recognition, so that the question of her future behaviour is rendered moot. In Coetzee's diegesis, the after-effects of trauma - be it rape or other forms of

${ }^{132}$ See page 97 of this thesis. 
abuse - are portrayed in detail and at length: or at least, I argue, this is one way in which Magda's narration might be read. 


\section{CONCLUSION}

In this thesis, I've compared Livy and Shakespeare's narratives with Coetzee's in order to determine the extent to which the conventions of the former persist or are disrupted in the latter, and what the consequences of a repetition and confirmation of these conventions - or, a deviation from these conventions - might be.

I have shown that Coetzee's novel In the Heart of the Country deviates, substantially, from the conventions espoused by Livy and Shakespeare. Where Livy and Shakespeare's narratives posit the possibility of viewing rape objectively from a "point-of-viewless perspective" (Rooney 89), Coetzee's novel omits an omniscient, authoritative narratorial perspective upon diegetic events, forcing readers to confront the perspectival and "speculative bias[es]" (In the Heart 21) inherent in its unreliable, unconventional first-person narration of rape. Whereas in Livy and Shakespeare no contest of meaning ${ }^{133}$ is staged between rapist and raped, Coetzee's narrative suggests that - even for one person involved in the rape, for example the raped woman - the task of understanding, naming, and determining the significance of an ostensible rape may involve the negotiation of potentially incommensurate meanings. Whereas in Livy and Shakespeare post-rape, self-inflicted ${ }^{134}$ violence functions to suggest that "the victim is responsible for her own destruction" (Bal 100), in Coetzee's diegesis violence may be interpreted as that which temporarily affords the protagonist analgesic relief from painful, unattainable desires. Magda's responses to violence (inflicted, in the novel, by her father and Hendrik) can, I have shown, be read to imply not that she is "responsible for her own destruction" but, rather, that she is coping, in a complex physiological and cognitive manner, with ongoing trauma.

In consequence, Coetzee provides a rape narrative which does indeed "leave the reader with uncomfortable, unanswerable questions" (Barnard, "J.M. Coetzee" 199). The question of what motivates rape is re-opened: Magda's narration suggests that Hendrik is impelled neither by lust for her ${ }^{135}$ nor by an urge to possess her. ${ }^{136}$ The descriptions of rape

\footnotetext{
133 The meaning of the rape, that is to say.

134 That is to say, violence inflicted by a rape victim upon herself, as is the case with Lucretia's suicide.

$135 \mathrm{By}$, for example, the lust which impels Tarquin to ravish the apparently irresistibly chaste and beautiful Lucretia (see pages 57 and 61 of this thesis). Magda renders moot the idea that beauty inspires Hendrik's
} 
in the novel are book-ended by passages describing arguments between Hendrik and Magda $^{137}$ - suggesting that the rape may represent some incarnation of Hendrik's apparent anger toward Magda - but because the narration excludes authoritative description of Hendrik's thoughts, omitting any focalisation via his perspective, readers can only speculate upon what motivates the rape and/or what, if anything, it is meant to achieve. Coetzee's narrative also re-opens the question of what, if anything, the rape is allegorical of: minus the sort of totalising internal readings provided in Livy and Shakespeare, one becomes aware that any allegorical interpretation of Magda's rape - as, for example, a figure for 'black peril, ${ }^{138}$ for a shift of power from whites to blacks in post-apartheid South Africa, or of Magda's perpetual subjection to forms of male authority - is "of necessity an extra-textual predilection of the reader" (Dodd "Naming" 157). So too does the assignment of any particular historical significance ${ }^{139}$ to the rape remain a readerly activity of narrative supplementation; Coetzee's novel only thematizes Magda's desire for the events of her life to be subsumed into a greater, potentially historiographical narrative, without ever indicating that this is accomplished or suggesting that the events of her life exude some sort of self-evident historical significance.

actions; in contrast to Lucretia's statement that her beauty "hath purloined" Tarquin's eyes (1651), Magda claims that she has "no beauty to lure him [Hendrik] on with" (121) and that she "cannot honestly see why he leaves his wife's bed for mine" (122). There is nothing in the Coetzee's novel to definitively confirm or cancel out the possibility that Hendrik is motivated by desirous lust for Magda.

${ }^{136}$ The pursuit of (matrimonial) possession provides the rationale for the rape of the Sabine women, as I argued on pages 43-4 in part one of this thesis. In Coetzee's novel, Magda sometimes expresses a desire to be 'adopted' into Hendrik's family. She imagines herself as his second wife, stating that "A man comes to Anna and he comes to me: we embrace him, we hold him inside us, we are his, he is ours" (124). After Hendrik and Anna leave the farm, she imagines saying to Hendrik - as though he could hear her - that if he were to return she "would cook your meals, I will even, if you like, try again to be your second woman" (134). To some extent, then, it may be argued that Magda sees possession as the (potential) point of (being forced to have) sex with Hendrik. However, nothing in the text confirms the idea that Hendrik himself is motivated to rape Magda because he wants to marry or, in some way, possess her.

${ }^{137}$ The passage within which the sexual encounters are first described opens with the description of an argument - between Magda and Hendrik - concerning Magda's failure to pay Hendrik the wages he is owed (113). Another shouting match, during the course of which Magda implores Hendrik to tell her "Why have $I$ to pay for other people's sins?" (128), immediately precedes Anna and Hendrik's departure from the farm.

138 'Black Peril' is a term that, "In the early decades of this [the twentieth] century," Cornwell claims, "recurred like a refrain in the South African debate about the native question" ("George Webb" 441). It functioned, Cornwell explains, "as the signifier for a range of emotions, ranging from sexual jealousy over the seduction of white women by black men to a general apprehension of native rebellion" but "was most commonly understood to refer to the threat of black rape" ("George Webb" 441). Cornwell argues that "the rape threat was essentially a rationalization of white men's fear of sexual competition from black men" ("George Webb" 141). John Pape delineates the significant consequences of this perceived threat, terming it a sometimes "fully hysterical obsession" which "spawned a wide range of legislation, including the prohibition of sexual relations between white women and black men. In addition, dozens of blacks were executed, both legally and extra-legally, for supposed 'black peril' violations. Yet for the most part, 'black peril' was a manufactured phenomenon" (699).

${ }^{139}$ In Livy, Joshel argues, the historical significance of narrated rapes is specified within the course of the narrative. "Livy urges a particular kind of reading," she asserts, by which readers "should understand the consequences of assuming particular subject positions" and recognise that "Bodily practices fit into a vision of building and collapsing empire: some result in imperial power; others bring decadence and destruction" (115). 
Rather, her persistent, desperate desire to be subsumed into some greater narrative is figuratively conveyed within the novel's last few pages when, using stones, she depicts herself, and spells out her desires, in an apparent effort to commune with flying "skycreatures" (In the Heart 145). ${ }^{140}$

As "uncomfortable" and/or "unanswerable" as these questions may be, I find Coetzee's exploratory, inconclusive approach to rape a preferable alternative - to the extent that I look to these narratives, that is to say, as "cultural scripts for action" (Detmer-Goebel 82 ) - to the answers provided by Livy and Shakespeare's narratives of rape. Perhaps the project of thinking through these questions, without seeking to determine concrete or universally applicable answers - considering, for example, why they are difficult to answer, and why it is so difficult to formulate a "basic terminology of rape" (Davidson 534) with which they might be discussed - is more conducive to the project of understanding rape in a manner that accounts for its 'split reality' ${ }^{141}$ and its 'interiority' (Bal 100). Coetzee has noted - regarding the question of what

the correct relationship ought to be between a representative of this failed or failing colonial movement, with this history of oppression behind it, on the one hand, and the part of the world where it sought and failed to establish itself and the people of that part of the world on the other hand (Interview with David Attwell, n. pag.)

- that his approach, be it a "dubious and hesitant one," is to assert that "it has been and may continue to be, in the time that is left to me, more productive to live out the question than to

\footnotetext{
${ }^{140}$ Rody writes that in "this final, lovely, loony stage" (178) of the novel, Magda, "having lost everything, resourcefully renews her hope for communication" by inventing "a whole new cast of characters with whom to desire conversation" (177). In one of many attempts to commune with the "flying machines" (In the Heart 138), Magda "builds a stone 'sketch of a woman's body in an openly inviting pose, but receives no response" (Rody 178). This part of the novel is reminiscent of the way in which the character Jacobus Coetzee - in Coetzee's first novel, Dusklands - figuratively imagines his own imprisonment in a "stony monologue" (Coetzee In the Heart 13). Joan Gillmer argues that Jacobus Coetzee describes "this state of mind" as "a condition in which the patriarchal sky god no longer lies with and impregnates the mothering earth" (110). When Magda suggests that the "skymen" (145) do not respond to her "sketch of a woman, lying on her back [. . . ] her legs parted" (145), her narration recalls the "desiccated mythographic terms" (Gillmer 110) in which Jacobus Coetzee figures his own isolation.

${ }^{141}$ I use this term earlier in this thesis (see page 37) to refer to MacKinnon's assertion that "women are also violated every day by men who have no idea of the meaning of their acts to women" (653).
} 
try to answer it in abstract terms"142 (Interview with David Attwell, n. pag.). I argue that his narrative representation of rape is constructed in the same spirit of living out - rather than answering - the relevant questions. In In the Heart of the Country Coetzee offers us a literary opportunity to think through complex questions that attach to rape rather than providing "an ideological construct” (Cornell 58) which urges us to accept conventional answers.

${ }^{142}$ Coetzee adds that "When I say I have "lived out" the question I mean I have lived it out not only in day to day life but in my fiction as well” (Interview with David Attwell, n. pag.) 


\section{WORKS CONSULTED}

“Acquiescence.” OED Online. 16 Nov. 2009.

http://dictionary.oed.com.helicon.vuw.ac.nz/cgi/entry/50001967?sin

gle $=1 \& q u e r y \_$type $=$word \&queryword $=$Acquiescence $\&$ first $=1 \& \max$

_to_show $=10$

“Analgesia.” OED Online. 16 Nov. 2009.

http://dictionary.oed.com.helicon.vuw.ac.nz/cgi/entry/50007860?sin

gle $=1 \& q u e r y \_t y p e=$ word \&queryword=analgesia\&first $=1 \&$ max $\_$to show $=10$

Attwell, David. J.M. Coetzee: South Africa and the Politics of Writing. Berkeley: University of California Press, 1993.

Attridge, Derek. "Ethical Modernism: Servants as Others in J.M. Coetzee's Early Fiction." Poetics Today 25.4 (2004): 653-71.

---. J.M. Coetzee and the Ethics of Reading. By Derek Attridge. Chicago: University of Chicago Press, 2004. 1-31.

Augustine, Saint, Bishop of Hippo. City of God. Ed. P.G. Walsh. Oxford: Oxbow Books, 2005.

Bachofen, J.J. Myth, Religion, and Mother Right: Selected Writings of J.J. Bachofen. Trans. Ralph Manheim. New Jersey: Princeton University Press, 1967.

Bal, Mieke. "Calling to Witness: Lucretia.” Looking In: The Art of Viewing. By Mieke Bal. London: Routledge, 2004. 93-116.

Barnard, Rita and J.M. Coetzee. "J.M. Coetzee's Disgrace and the South African Pastoral." Contemporary Literature 44.2 (2003): 199-224.

Bell, Susan G. Women, from the Greeks to the French Revolution. Stanford: Stanford University Press, 1973.

Blunt, Alison and Gillian Rose, eds. Writing Women and Space: Colonial and Postcolonial Geographies. New York: The Guilford Press, 1994.

Boehmer, Elleke. "Not Saying Sorry, Not Speaking Pain.” Interventions 4.3 (2002): 342-51.

Briganti, Chiara. "A Bored Spinster with a Locked Diary: the Politics of Hysteria in In The Heart of the Country." Research in African Literatures 25.4 (1994): 33-49. 
Brooks, Peter. Body Work. Cambridge, Mass.: Harvard University Press, 1993.

---. Reading for the Plot: Design and Intention in Narrative. New York: Vintage, 1985.

Richard Brucher. " 'Tragedy Laugh On': Comic Violence in Titus Andronicus." Renaissance Drama 10 (1979): 71-92.

Bueler, Lois E. The Tested Woman Plot: Women's Choices, Men's Judgments, and the shaping of stories. Columbus: Ohio State University Press, 2001.

Burton, Joel R. J.M. Coetzee's Impetus: Toward a Theory of Ethical Confession. Halifax: Dalhousie University, 2005.

Cahill, Ann J. "Foucault, Rape, and the Construction of the Feminine Body." Hypatia 15.1 (2000): 43-63.

Carroll, Margaret D. "The Erotics of Absolutism: Rubens and the Mystification of Sexual Violence." The Expanding Discourse: Feminism and Art History. Ed. Norma Broude and Mary D. Garrard. New York: Harper Collins, 1992. 139-159.

“Chastity.” Encyclopaedia of Religion and Ethics. Edinburgh: T. \& T. Clark, 1910.

“Chastity.” OED Online. 16 Nov. 2009.

http://dictionary.oed.com.helicon.vuw.ac.nz/cgi/entry/50037182?single=1\&query type $=$ word\&queryword $=$ Chastity\&first $=1 \& \max \_$to $\_$show $=10$

Coetzee, J.M. Disgrace. London: Vintage, 1999.

---. Doubling the Point: Essays and Interviews. Ed. David Attwell. Cambridge, Mass.: Harvard University Press, 1992.

---. Elizabeth Costello. Sydney: Knopf, 2003.

---. Giving Offense: Essays on Censorship. Chicago: University of Chicago Press, 1996.

---. Interview with David Attwell. “An Exclusive Interview with J.M. Coetzee.” Kultur \& Nöje 8 December 2003. 14 Nov. 2009 http://www.dn.se/ kultur-noje/an-exclusiveinterview-with-j-m-coetzee-1.227254

---. Interview with Folke Rhedin. "Interview with J.M. Coetzee.” Kunapipi 6.1 (1984): 6-11.

---. In the Heart of the Country. London: Vintage, 2004.

---. "Into the Dark Chamber: The Writer and the South African State." Doubling the Point 361-68.

“Communion.” OED Online. 16 Nov. 2009.

http://dictionary.oed.com.helicon.vuw.ac.nz/cgi/entry/50045222?sin

gle $=1 \& q u e r y \_$type $=$word\&queryword=communion\&first $=1 \& \max \_t$

o show $=10$ 
Cornell, T.J. "The Value of the Literary Tradition Concerning Archaic Rome.” Social Struggles in Archaic Rome. Ed. K.A. Raaflaub. Berkeley: University of California Press, 1986. 52-76.

Cornwell, Gareth. "Realism, Rape, and J.M. Coetzee's Disgrace.” Critique 43.4 (2002): 307322.

---. “George Webb Hardy's The Black Peril and the Social Meaning of 'Black Peril' in Early Twentieth-Century South Africa.” Journal of Southern African Studies 22.3 (1996): 441-53.

Cray, Jonathan. Paris / Manhattan: Writings on Art. London: Verso, 2004.

Crespi, Giuseppe Maria. Tarquin and Lucretia. 1695-1700. National Gallery of Art, Washington. 14 Nov. 2009. http://www.nga.gov/collection/gallery/gg33/gg33-41640lit.html

Culler, Jonathan. "Reading as a Woman." On Deconstruction: Theory and Criticism after Structuralism. By Jonathan Culler. Ithaca, NY: Cornell University Press, 1982. 43-63. Currie, Mark. Postmodern Narrative Theory. Hampshire: Palgrave, 1998.

Davidson, Arnold I. The Emergence of Sexuality: Historical Epistemology and the Formation of Concepts. Cambridge, Massachusetts: Harvard University Press, 2001. Davidson, James. "Reassuring the Patriarchy." The Classical Review 50.2 (2000): 532-6. Detmer-Goebel, Emily. “The Need for Lavinia's Voice: Titus Andronicus and the Telling of Rape.” Shakespeare Studies 29 (2001): 75-94.

Dodd, Josephine. 'Naming and Framing: Naturalization and Colonization in J. M. Coetzee's In the Heart of the Country." World Literature Written in English 27.2 (1987): 15361.

---. Power and Knowledge in the Fiction of J.M. Coetzee. Alberta: University of Alberta Press, 1987.

---. "The South African Literary Establishment and the Textual Production of 'Woman': J.M. Coetzee and Lewis Nkosi." South African Feminisms: Writing, Theory, and Criticism, 1990-1994. Ed. M.J. Daymond. New York: Garland, 1996. 327-40.

Donaldson, Ian. The Rapes of Lucretia: A Myth and its Transformations. Oxford: Clarendon Press, 1982.

Driver, Dorothy. "Women and Nature, Women as Objects of Exchange: Towards a Feminist Analysis of South African Literature." Perspectives on South African Literature. Ed. 
Michael Chapman, Colin Gardner, and Es'kia Mphahlele. Parklands: Ad. Donker, 1992. 454-74.

---. “ 'Woman' as Sign in the South African Colonial Enterprise.” Journal of Literary studies / Tydskrif vir literatuurwetenskap 4.1 (1988): 3-20.

Dürer, Albrecht. Suicide of Lucretia. (1518). Alte Pinakothek, Munich. 14. Nov. 2009. http://www.humanitiesweb.org/human.php?s=g\&p=c\&a=p\&ID=723

Durrant, Samuel. "Bearing Witness to Apartheid: J.M. Coetzee's Inconsolable Works of Mourning." Contemporary Literature 40.3 (1999): 430-63.

Eagleton, Mary. (ed). Feminist Literary Criticism. London: Longman, 1991.

---. “The Problem of Alice Walker's ‘Advancing Luna - and Ida B. Wells' and J.M.

Coetzee's Disgrace." Feminist Theory 2.2 (2001): 189-203.

Edelman, Gerald. Neural Darwinism. New York: Basic Books, 1987.

Ellman, Maud. "The Power to Tell: Rape, Race and Writing in Afro-American Women's Fiction." An Introduction to Contemporary Fiction: International Writing in English since 1970. Ed. Rod Mengham. Cambridge, UK: Polity, 1999. 32-52.

Engelstein, Stefani. “Sibling Incest and Cultural Voyeurism in Guenderode's Udohla and Thomas Mann's Waelsungenblut.” The German Quarterly 77.3 (2004): 278-99.

Erhlich, Susan. Representing Rape: Language and Sexual Consent. New York: Routledge, 2001.

Estrich, Susan. Real Rape. Cambridge MA: Harvard University Press, 1987.

Ferguson, Frances. "Rape and the Rise of the Novel." Representations 20 (1987): 88-112.

Ferriere, Claude-Joseph de. Dictionnaire de Droit et de Pratique (2eme édition). Paris: Chez Brunet Fils, 1740.

Flanagan, Joseph. "The Seduction of History: Trauma, Re-Memory, and the Ethics of the Real." Clio 31.4 (2002): 387-402.

Fleming, Richard and Michael Payne. Criticism, History, and Intertextuality. Cranbury, NJ: Bucknell University Press, 1988.

Foucault, Michel. The History of Sexuality Volume 1: Introduction. Trans. Robert Hurley. New York: Vintage, 1980.

---. The History of Sexuality Volume 2: The Use of Pleasure. Trans. Robert Hurley. New York: Vintage, 1980.

---. Politics, Philosophy, Culture: Interviews and Other Writings, 1977-1984. Ed. Lawrence D. Kritzman. Trans. Alan Sheridan. New York: Routledge, 1988. 
---. Power. Vol. 3 of Essential Works of Foucault: 1954-1984. Ed. James D. Faubion. Trans. Robert Hurley et al. New York: New Press, 2000.

Gajowski, Evelyn. The Art of Loving: Female Subjectivity and Male Discursive Traditions in Shakespeare's Tragedies. Cranbury: Associated University Press, 1992.

Gamel, Mary-Kay. "Reading 'Reality.'” Helios 17.2 (1990): 171-4.

Gavey, Nicola. Just Sex? The Cultural Scaffolding of Rape. London: Routledge, 2005.

“Generalisation.” A Dictionary of Psychology. Oxford: Oxford University Press, 2001.

Gentileschi, Artemisia. Lucretia. 1642-43. Museo di Capodimonte, Naples. 14 Nov. 2009. http://www.artemisia-gentileschi.com/lucretia1.html

Gilman, Charlotte Perkins. 'The Yellow Wallpaper' and Other Stories. Mineola: Dover, 1997.

Giordano, Luca. The Rape of the Sabine Women. 1672-74. National Gallery of Australia. 14 Nov. 2009. http://cs.nga.gov.au/Detail.cfm?IRN=23215

Glenn, Ian. "Game Hunting in In the Heart of the Country." Critical Perspectives on J.M. Coetzee. Ed. Graham Huggan and Stephen Watson. New York: Macmillan, 1996. 120-137.

Goldberg, Jonathan. "Shakespearean Inscriptions: The Voicing of Power.” Parker and Hartman 117-38.

Goldhill, Simon. Foucault's Virginity: Ancient Erotic Fiction and the History of Sexuality. Cambridge, UK: Cambridge University Press, 1995.

Graham, Dee L.R., Edna I. Rawlings, Kim Ihms, Diane Latimer, Janet Foliano, Alicia Thompson, Kelly Suttman, Mary Farrington, Rachel Hacker. “A Scale for Identifying 'Stockholm Syndrome' Reactions in Young Dating Women: Factor Structure, Reliability, and Validity." Violence and Victims 10.1 (1995): 3-22.

Graham, Lucy Valerie. “ 'A Hidden Side to the Story:' Reading Rape in Recent South African Literature." Kunapipi 24.1-2: 9-24.

---. "Reading the Unspeakable: Rape in J.M. Coetzee's Disgrace." Journal of South African Studies, 29.2 (2003): 433-44.

Helliwell, Christine. “ 'It's Only a Penis': Rape, Feminism, and Difference.” Signs 25.3 (2000): 789-816.

Hesford, Wendy S. "Reading Rape Stories: Material Rhetoric and the Trauma of Representation.” College English 62.2 (1999): 192-221. 
Heyns, Michiel. “The Whole Country's Truth: Confession and Narrative in Recent White South African Writing." Modern Fiction Studies 46.1 (2000): 42-66.

Higgins, Lynn A. and Brenda R. Silver (Eds). Rape and Representation. New York: Columbia University Press, 1991.

Jacobs, Johan U. "Gender-Bending and Code-Switching in the South African Novel: A Postcolonial Model." Deep hiStories: Gender and Colonialism in Southern Africa. Ed. Wendy Woodward, Patricia Hayes, and Gary Minkley. Amsterdam: Rodopi, 2002. 283-301.

Jacobus, Mary. "Is there a Woman in this Text?" Reading Woman: Essays in Feminist Criticism. By Mary Jacobus. New York: Columbia University Press, 1986. 83-109. Jed, Stephanie H. Chaste Thinking: The Rape of Lucretia and the Birth of Humanism. Bloomington: Indiana University Press, 1989.

Joplin, Patricia Klindienst. "Ritual Work on Human Flesh: Livy's Lucretia and the Rape of the Body Politic." Helios 17.1 (1990): 51-70.

---. “The Voice of the Shuttle is Ours.” Higgins and Silver 35-64.

Joshel, Sandra R. "The Body Female and the Body Politic.” Richlin 112-30.

Kahn, Coppelia. Roman Shakespeare: Warriors, wounds and women. London: Routledge, 1997.

Kendall, Gillian. "Lend me thy hand: Metaphor and Mayhem in Titus Andronicus." Shakespeare Quarterly 40.3 (1989): 299-316.

Kiefer, Otto. Sexual Life in Ancient Rome. London: Abbey Library, 1976.

Kossew, Sue. “'Women's Words': A Reading of J.M. Coetzee's Women Narrators.” Critical Essays on J. M. Coetzee. Ed. Sue Kossew. New York: G. K. Hall, 1998. 166-179.

Laplanche, J., and J.-B. Pontalis. The Language of Psychoanalysis. Trans. Donald Nicholson-Smith. New York: Norton, 1973.

MacKinnon, Catherine A. "Feminism, Marxism, Method, and the State: Toward Feminist Jurisprudence.” Signs 8.4 (1983): 635-658.

Marais, Michael. “ 'Little Enough, Less than Little: Nothing': Ethics, Engagement, and Change in the Fiction of J.M. Coetzee." Modern Fiction Studies 46.1 (2000): 159-82. Martin, Biddy. "Feminism, Criticism, and Foucault." New German Critique 27 (1982): 3-30. "Metonymy.” OED Online. 16 Nov. 2009. http://dictionary.oed.com.helicon. vuw.ac.nz/cgi/entry/00307897?single=1\&query_type=word\&queryword=metonymy \&first $=1 \& \max$ toshow $=10$ 
Mulvey, Laura. "Pandora: Topgraphies of the Mask and Curiosity." Sexuality and Space. Ed. Beatriz Colomina. New York: Princeton Architectural Press, 1992. 52-72.

O'Farrell, Clare. Foucault: The Legacy. Kelvin Grove: Queensland University of Technology, 1997.

Oksala, Johanna. "Anarchic Bodies: Foucault and the Feminist Question of Experience." Hypatia 19.4 (2004): 97-119.

Orlandini, Alvise. "Repetition Compulsion in a Trauma Victim: Is the 'Analgesia Principle' Beyond the Pleasure Principle? Clinical Implications." Journal of the American Academy of Psychoanalysis and Dynamic Psychiatry 32.3 (2004): 525-40.

Ormand, Kirk. "Impossible Lesbians in Ovid's Metamorphoses." Gendered Dynamics in Latin Love Poetry. Ed. Ronnie Ancona and Ellen Greene. Baltimore: John Hopkins University Press, 2005: 79-110.

Ovid. "The Art of Love.” The Love poems. Ed. E.J. Kenney. Trans. A.D. Melville. Oxford: Oxford University Press, 2008: 87-149.

---. Metamorphoses. Ed. Sir Samuel Garth. Trans. John Dryden et al.Hertfordshire: Wordsworth, 1998.

Pape, John. "Black and White: the 'Perils of Sex' in Colonial Zimbabwe. Journal of Southern African Studies 16.4 (1990): 699-720.

Parker, Andrew, Mary Russo, Doris Sommer, and Patricia Yaeger (eds). Nationalisms and Sexualities. New York: Routledge, 1992.

Parker, Holt N. "Why Were the Vestal Virgins? Or the Chastity of Women and of the Safety of the Roman State.” American Journal of Philology 125 (2004): 563-601.

Parker, Patricia and Geoffrey H. Hartman (eds). Shakespeare and the Question of Theory. New York: Methuen, 1985.

Parker, Robert Dale. Faulkner and the Novelistic Imagination. Urbana: University of Illinois Press, 1985.

"Pharmakos." OED Online. 16 Nov. 2000 http://dictionary.oed.com.helicon.vuw.ac.nz/ cgi/entry $/ 50177191$ ? single $=1 \&$ query type $=$ word \&queryword $=$ Pharmakos $\&$ first $=1 \&$ max_toshow $=10$

Plaza, Monique. "Our Damages and Their Compensation. Rape: The Will Not to Know of Michel Foucault." Feminist Issues 1.3 (1981): 25-35.

Poussin, Nicholas. The Rape of the Sabine Women. 1635. The Metropolitan Museum of Art, New York. 14 Nov. 2009. http://www.etchings.com/erin/files/sabine.html 
“Projection.” OED Online. 16 Nov. 2009. http://dictionary.oed.com.helicon.vuw.ac.nz/ cgi/entry/50189697?single=1\&query type=word\&queryword=projection $\&$ first $=1 \& \mathrm{~m}$ ax to

Reef, Anne. "Representations of Rape in Apartheid and Post-apartheid South African Literature." Textual Ethos Studies or Locating Ethics. Ed. Anna Fahraeus and AnnKatrin Jonsson. Amsterdam: Rodopi, 2005.

Richlin, Amy (ed.) Pornography and Representation in Greece and Rome. New York: Oxford University Press, 1992.

Roberts, Diane. "Ravished Belles: Stories of Rape and Resistance in Flags in the Dust and Sanctuary." The Faulkner Journal 4 (1988/89): 21- 35.

Rody, Caroline. “The Mad Colonial Daughter's Revolt: J.M. Coetzee's In the Heart of the Country.” The South Atlantic Quarterly 93.1 (1994): 157-180.

Rubens, Peter Paul. The Rape of the Sabine Women. 1635-40. The National Gallery, London. 14 Nov. 2009. http://www.nationalgallery.org.uk/paintings/peter-paul-rubens-therape-of-the-sabine-women

Rooney, Ellen. “ 'A Little More Than Persuading:' Tess and the Subject of Sexual Violence." Higgins and Silver 87-114.

Salzman-Mitchell, Patricia B. A Web of Fantasies: Gaze, Image, and Gender in Ovid's Metamorphoses. Ohio: Ohio State University, 2005.

Samuelson, Meg. "The Rainbow Womb: Rape and Race in South African Fiction of the Transition.” Kunapipi 24.1-2 (2002): 88-100.

Sanders, Mark. "Truth, Telling, Questioning: The Truth and Reconciliation Commission, Antjie Krog's Country of My Skull, and Literature after Apartheid.” Modern Fiction Studies 46.1 (2000): 13-41.

Santello, M. D., \& Leitenberg, H. "Sexual Assault by an Acquaintance: Methods of Coping and Later Psychological Adjustment. Violence and Victims 8 (1993): 91-104.

Sheckels, Theodore F., Jr. The Lion on the Freeway: A Thematic Introduction to Contemporary South African Literature in English. New York: Lang, 1996.

Scheel, Kathleen M. "Incest, Repression, and Repetition-Compulsion: The Case of Faulkner's Temple Drake." Mosaic: a Journal for the Interdisciplinary Study of Literature 30.4 (1997): no. pag. 
Scully, Pamela. "Rape, Race, and Colonial Culture: The Sexual Politics of Identity in the $19^{\text {th }}$-Century Cape Colony, South Africa.” American Historical Review 100.2 (1995): 335-59.

Sedgwick, Eve Kosofsky. Epistemology of the Closet. Berkeley: University of California Press, 1990.

Shakespeare, William. "The Rape of Lucrece." The Poems: Venus and Adonis, The Rape of Lucrece, ThePhoenix and the Turtle, The Passionate Pilgrim, A Lover's Complaint. Ed. John Roe. Cambridge, UK: Cambridge University Press, 2006. 147-238. Sharrock, Alison R. "Looking at Looking: Can You Resist a Reading?" The Roman Gaze: Vision, Power, and the Body. Ed. David Fredrick. Baltimore: Johns Hopkins University Press, 2002. 265-95.

Sielke, Sabine. Reading Rape: The Rhetoric of Sexual Violence in American Literature and Culture 1790-1990. Princeton: Princeton University Press, 2002.

Smart, Barry. "Facing the Body: Goffman, Levinas and the Subject of Ethics." Body \& Society 2.2 (1996): 67-78.

Smith, Barbara Herrnstein. Contingencies of Value: Alternative Perspectives for Critical Theory. Cambridge, Massachussets: Harvard University Press, 1988.

Stockton, Sharon. The Economics of Fantasy: Rape in Twentieth-Century Literature. Columbus: Ohio State University Press, 2006.

"Synecdoche." OED Online. 16 Nov. 2009. http://dictionary.oed.com.helicon.vuw.ac.nz/ cgi/entry $/ 50245360$ ?single $=1 \&$ query type $=$ word $\&$ queryword $=$ Synecdoche $\&$ first $=1 \&$ $\underline{\max }$ to show $=10$

Tanner, Laura E. Intimate Violence: Reading Rape in Twentieth-Century Fiction. Bloomington: Indiana University Press, 1994.

Tiepolo, Giambattista. Tarquin and Lucretia. (1750). Staatsgalerie am Shäzler-Palais, Städtische Kunstsammlungen, Augsburg. 14 Nov. 2009. http://www.artchive. com/artchive/T/tiepolo/tiepolo tarquin.jpg.html

Tomaselli, Sylvana and Roy Porter (eds). Rape. Oxford: Blackwell, 1986. Turcan, Robert. The Gods of Ancient Rome: Religion in Everyday Life from Archaic to Imperial Times. New York: Routledge, 2001.

van Rijn, Rembrandt. Lucretia. (1666). Minneapolis Institute of Arts, Minneapolis. 14 Nov. 2009. http://www.artsmia.org/viewer/detail.php?v=12\&id=529 
VanZanten Gallagher, Susan. A Story of South Africa: J.M. Coetzee's Fiction in Context. Cambridge, Mass. and London: Harvard University Press, 1991.

Vecellio, Titian. The Rape of Lucretia. (1568-71). Fitzwilliam Museum, Cambridge. 14 Nov. 2009. http://www.artchive.com/artchive/T/titian/titian_lucretia.jpg.html

Veronese, Paolo. Lucretia. (1585). Musée de Luxembourg, Paris. 14 Nov. 2009. http://www.culturekiosque.com/art/exhibiti/veronese.html

"Vesta." OED Online. 16 Nov. 2009. http://dictionary.oed.com.helicon.vuw.ac.nz/cgi/entry/ $\underline{50276913 ? \sin }$ gle=1\&query_type=word\&queryword=vesta\&first=1\&max_to_sho $\mathrm{W}=10$

"Vestal.” OED Online. 16 Nov. 2009. http://dictionary.oed.com.helicon.vuw.ac.nz/ cgi/entry/50276914?query type=word\&queryword=vesta\&first=1\&max_to_show=1 $\underline{0 \& \text { single }=1 \& \text { sort } t y p e=a l p h a}$

Vickers, Nancy J. “ ‘The Blazon of Sweet Beauty’s Best': Shakespeare's Lucrece.” Parker and Hartman 95-115.

Wall, Kathleen. The Callisto Myth from Ovid to Atwood: Initiation and Rape in Literature. Kingston: McGill-Queen's University Press, 1988.

Warshaw, Robin. I Never Called it Rape: the Ms. Report on Recognizing, Fighting, and Surviving Date and Acquaintance Rape. New York: Harper \& Row, 1988.

Watson, Stephen. "Colonialism and the Novels of J.M. Coetzee." Research in African Literatures 17.3 (1986): 370-92.

Wohlpart, James. "A (Sub)Version of the Language of Power: Narrative and Narrative Technique in J.M. Coetzee's In the Heart of the Country." Critique 35.4 (1994): 21928.

Wolfthal, Diane. Images of Rape: The 'Heroic' Tradition and its Alternatives. Cambridge, UK: Cambridge University Press, 1999.

Wright, Laura. Writing 'Out of All the Camps': J.M. Coetzee's Narratives of Displacement. NY and London: Routledge, 2006.

Yalom, Marilyn. A History of the Wife. London: Pandora, 2001.

Zeitlin, Froma. "Configurations of Rape in Greek Myth.” Tomaselli and Porter 122-51.

Zinn, Emily R. "Rediscovery of the Magical: On Fairy Tales, Feminism, and the New South Africa.” Modern Fiction Studies 46.1 (2000): 246-69. 